Prepared in cooperation with the U.S. Army Corps of Engineers

\title{
Influence of Cougar Reservoir Drawdown on Sediment and DDT Transport and Deposition in the McKenzie River Basin, Oregon, Water Years 2002-04
}

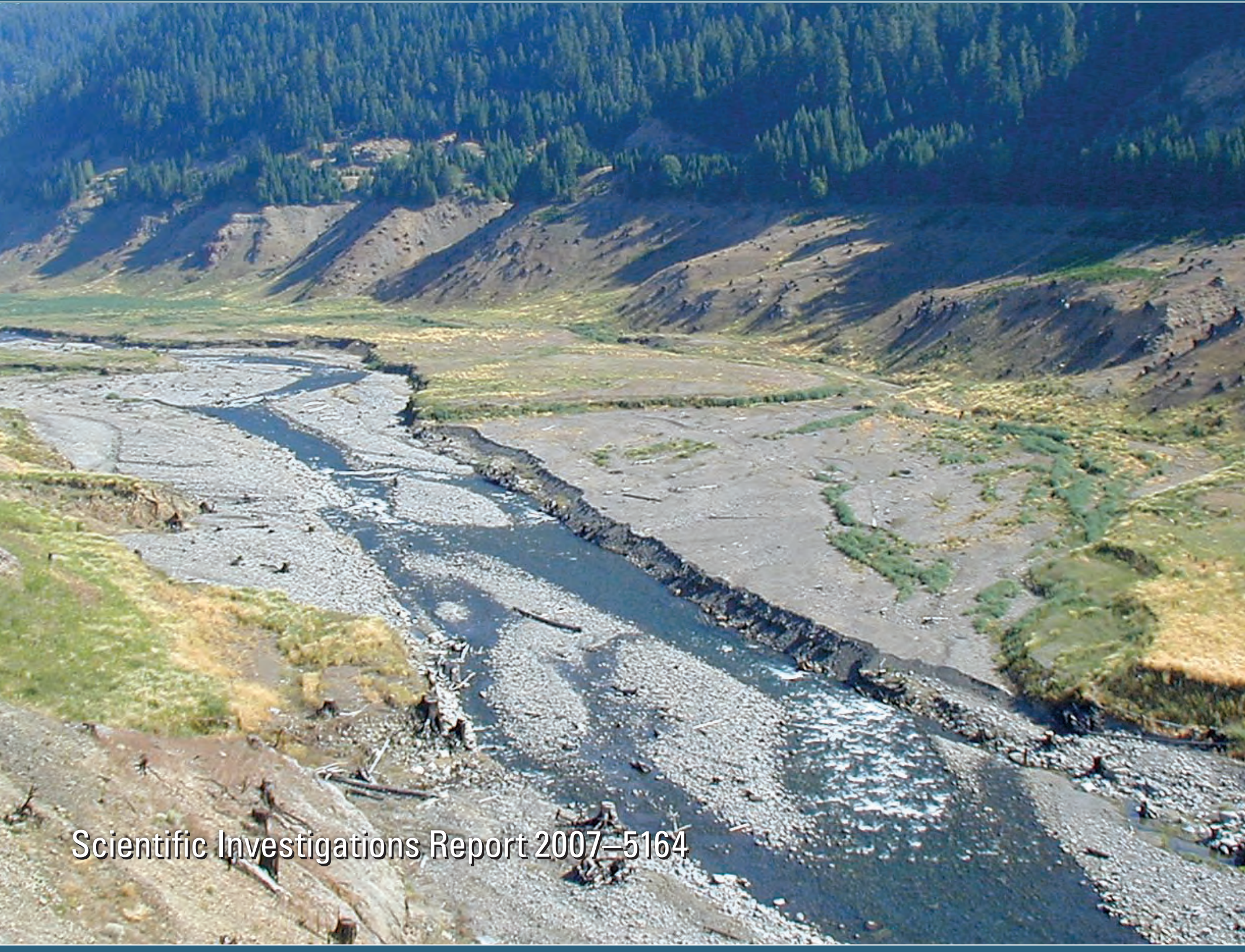


Front Cover: Cougar Reservoir near Terwilliger Hot Springs, Oregon. (Photograph taken by Chauncey Anderson, U.S. Geological Survey.)

Back Cover: Cougar Reservoir withdrawal tower upon completion of construction in 2005. (Photograph from U.S. Army Corps of Engineers.) 


\section{Influence of Cougar Reservoir Drawdown on Sediment and DDT Transport and Deposition in the McKenzie River Basin, Oregon, Water Years 2002-04}

By Chauncey W. Anderson

Prepared in cooperation with the U.S. Army Corps of Engineers

Scientific Investigations Report 2007-5164 


\title{
U.S. Department of the Interior DIRK KEMPTHORNE, Secretary
}

\author{
U.S. Geological Survey \\ Mark D. Myers, Director
}

\section{U.S. Geological Survey, Reston, Virginia: 2007}

For product and ordering information:

World Wide Web: http://www.usgs.gov/pubprod

Telephone: 1-888-ASK-USGS

For more information on the USGS--the Federal source for science about the Earth, its natural and living resources, natural hazards, and the environment:

World Wide Web: http://www.usgs.gov

Telephone: 1-888-ASK-USGS

Any use of trade, product, or firm names is for descriptive purposes only and does not imply endorsement by the U.S. Government.

Although this report is in the public domain, permission must be secured from the individual copyright owners to reproduce any copyrighted materials contained within this report.

Suggested citation:

Anderson, C., 2007, Influence of Cougar Reservoir drawdown on sediment and DDT transport and deposition in the McKenzie River basin, Oregon, water years 2002-04: U.S. Geological Survey Scientific Investigations Report 2007-5164, 42 p. 


\section{Contents}

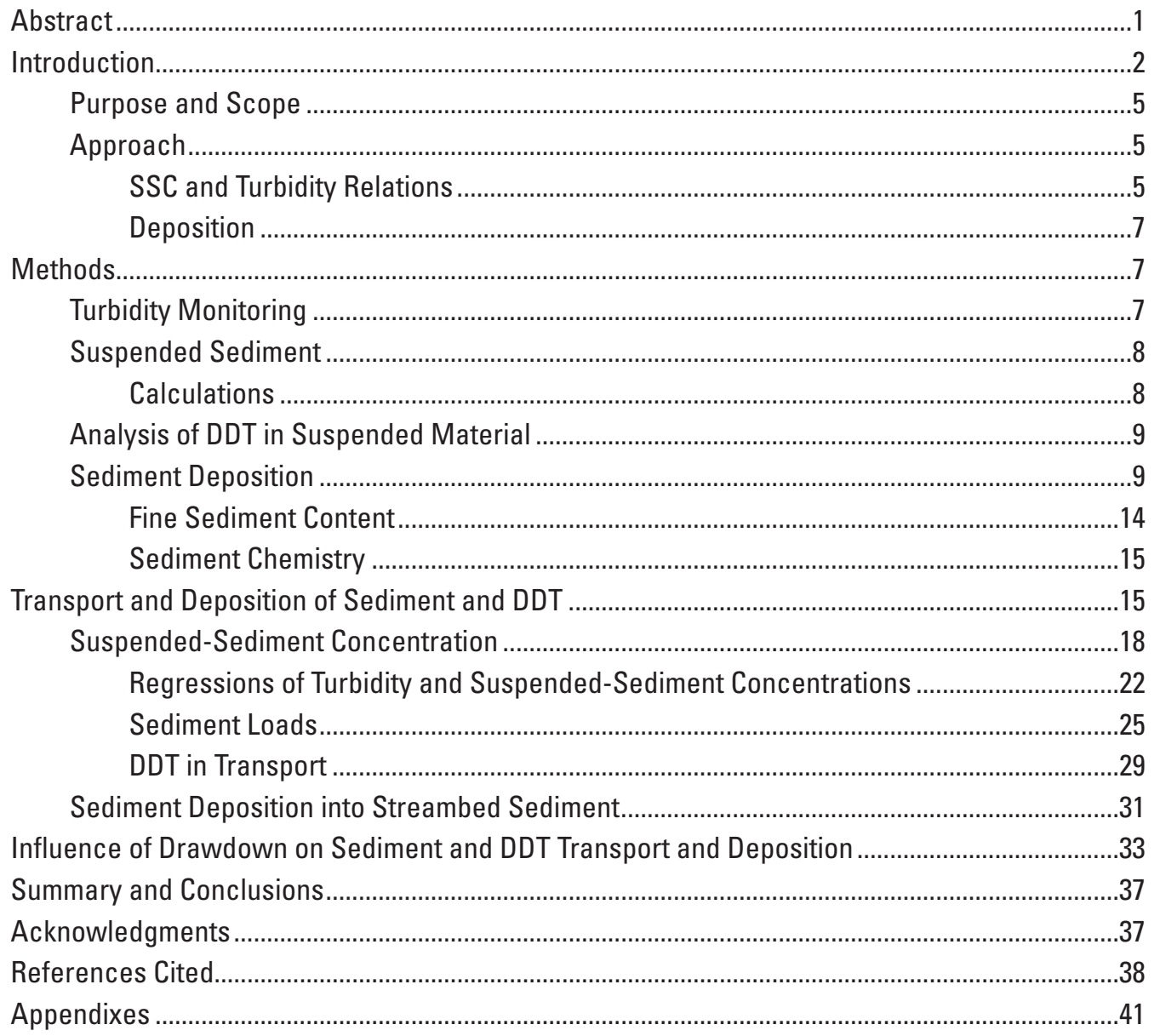




\section{Figures}

Figure 1. Map showing location of study area with sampling locations, McKenzie River basin, Oregon

Figure 2. Photograph showing aerial view of Cougar Reservoir during drawdown, with exposed upstream deltaic sediments, during the summer of 2002

Figure 3. Graph showing discharge and turbidity at South Fork McKenzie River near Rainbow (CGRO) downstream of Cougar Reservoir, Oregon, spring and summer of 2002

Figure 4. Photographs showing installation process for infiltration bags for estimation of fine sediment deposition in the McKenzie River, Oregon

Figure 5. Photographs showing infiltration bag retrieval process for measurement of deposition of fine sediment and DDT plus metabolites in the McKenzie River, Oregon, August 2004

Figure 6. Graphs showing discharge and turbidity at sampling sites in the McKenzie River basin, Oregon, water years 2002-04

Figure 7. Graph showing median percentage of fine material (less than 0.063 millimeter) and standard deviation in percentage of fine material of suspended sediment at gaging stations in the McKenzie River basin, Oregon, 2003-04

Figure 8. Graphs showing regression using linear, and power-function regression lines for turbidity and concentration of suspended sediment at study sites in the McKenzie River basin, Oregon, water years 2002-04

Figure 9. Photographs showing channel changes in the South Fork McKenzie River within the Cougar Reservoir drawdown area, January 29-31, 2003, as seen from the Terwilliger Hot Springs parking area

Figure 10. Graph showing annual load and discharge-weighted concentration of suspended sediment at the inflow to and outflow from Cougar Reservoir, Oregon

Figure 11. Graph showing percentage of sediment less than 0.063 millimeters in diameter in infiltration bags after 1 year deployment in the McKenzie River, Oregon, 2004

Figure 12. Graph showing relation of sand, silt, and clay fractions recovered from infiltration bags and freeze cores in the McKenzie River, Oregon 


\section{Tables}

Table 1. Stations used to monitor discharge, turbidity, and sediment in the McKenzie River basin, Oregon, 2002-04.....

Table 2. Suspended-sediment concentrations and associated turbidity during storm sampling in the McKenzie River basin, Oregon, 2003-04

Table 3. Regression equations and correlation coefficients for relations between turbidity and suspended-sediment concentrations, McKenzie River basin, Oregon

Table 4. Estimated annual discharge, suspended-sediment load, and dischargeweighted suspended-sediment concentrations at gaging stations in the McKenzie River, Oregon, water years 2002-04, as derived from continuous measurements of discharge and turbidity, and regressions of turbidity and suspended-sediment concentration

Table 5. Concentrations of suspended sediment, suspended organic carbon, and DDT and metabolites transported during storms in the McKenzie River basin, Oregon, 2003

Table 6. Total mass of sediment and percent of fine materials, and concentrations of DDT and metabolites, in infiltration bags deployed in the McKenzie River, Oregon, August 2003-July 2004 .....

Table 7. Comparison of fine material deposition in McKenzie River bed sediment measured from freeze cores during July 2002 and infiltration bags deployed from August 2003-July 2004 


\title{
Conversion Factors, Datums, and Abbreviated Water-Quality Units
}

\author{
Conversion Factors
}

\begin{tabular}{lcl}
\hline Multiply & By & To obtain \\
\hline acre & 4,047 & square meter $\left(\mathrm{m}^{2}\right)$ \\
acre & 0.4047 & hectare $($ ha) \\
acre-ft $(\mathrm{acre}-\mathrm{ft})$ & 1,233 & cubic meter $\left(\mathrm{m}^{3}\right)$ \\
acre-ft $(\mathrm{acre}-\mathrm{ft})$ & 0.001233 & cubic hectometer $\left(\mathrm{hm}^{3}\right)$ \\
cubic foot $\left(\mathrm{ft}^{3}\right)$ & 28.32 & cubic decimeter $\left(\mathrm{dm}^{3}\right)$ \\
cubic foot $\left(\mathrm{ft}^{3}\right)$ & 0.02832 & cubic meter $\left(\mathrm{m}^{3}\right)$ \\
cubic foot per second $\left(\mathrm{ft}^{3} / \mathrm{s}\right)$ & 0.02832 & cubic meter per second $\left(\mathrm{m}^{3} / \mathrm{s}\right)$ \\
foot $(\mathrm{ft})$ & 0.3048 & meter $(\mathrm{m})$ \\
inch (in.) & 2.54 & centimeter $(\mathrm{cm})$ \\
inch $($ in.) & 25.4 & millimeter per year $(\mathrm{mm} / \mathrm{yr})$ \\
mile $(\mathrm{mi})$ & 1.609 & kilometer $(\mathrm{km})$ \\
ton, short $(2,000 \mathrm{lb})$ & 0.9072 & megagram $(\mathrm{Mg})$ \\
ton per day $(\mathrm{ton} / \mathrm{d})$ & 0.9072 & metric ton per day \\
ton per year $(\mathrm{ton} / \mathrm{yr})$ & 0.9072 & metric ton per year \\
ounce, avoirdupois $(\mathrm{oz})$ & 28.35 & gram $(\mathrm{g})$ \\
square foot $\left(\mathrm{ft}^{2}\right)$ & 929.0 & square centimeter $\left(\mathrm{cm}^{2}\right)$ \\
square foot $\left(\mathrm{ft}^{2}\right)$ & 0.09290 & square meter $\left(\mathrm{m}^{2}\right)$ \\
square mile $\left(\mathrm{mi}{ }^{2}\right)$ & 259.0 & hectare $($ ha) \\
square mile $\left(\mathrm{mi}{ }^{2}\right)$ & 2.590 & square kilometer $\left(\mathrm{km}{ }^{2}\right)$ \\
\hline
\end{tabular}

Temperature in degrees Celsius $\left({ }^{\circ} \mathrm{C}\right)$ may be converted to degrees Fahrenheit $\left({ }^{\circ} \mathrm{F}\right)$ as follows:

$$
{ }^{\circ} \mathrm{F}=\left(1.8 x^{\circ} \mathrm{C}\right)+32 .
$$

Temperature in degrees Fahrenheit $\left({ }^{\circ} \mathrm{F}\right)$ may be converted to degrees Celsius $\left({ }^{\circ} \mathrm{C}\right)$ as follows:

$$
{ }^{\circ} \mathrm{C}=\left({ }^{\circ} \mathrm{F}-32\right) / 1.8 \text {. }
$$

Datums

Vertical coordinate information is referenced to the North American Vertical Datum 1988 (NAVD 88).

Horizontal coordinate information is referenced to the North American Datum 1983 (NAD 83).

Altitude, as used in this report, refers to distance above the vertical datum.

Water-Quality Units

Specific conductance is reported in microsiemens per centimeter at 25 degrees Celsius $(\mu \mathrm{S} / \mathrm{cm}$ at $\left.25^{\circ} \mathrm{C}\right)$.

Concentrations of chemical constituents in water are reported either in milligrams per liter $(\mathrm{mg} / \mathrm{L})$ or micrograms per liter $(\mu \mathrm{g} / \mathrm{L})$.

Concentrations of chemical constituents in water and sediment are reported either in micrograms per kilogram $(\mu \mathrm{g} / \mathrm{kg}$ ) or micrograms per liter $(\mu \mathrm{g} / \mathrm{L})$, which is equivalent to parts per billion. 


\title{
Influence of Cougar Reservoir Drawdown on Sediment and DDT Transport and Deposition in the McKenzie River Basin, Oregon, Water Years 2002-04
}

\author{
By Chauncey W. Anderson
}

\begin{abstract}
Construction of a selective withdrawal tower at Cougar Reservoir in the South Fork McKenzie River, Oregon, during 2002-05 resulted in a prolonged release of sediment and high-turbidity water to downstream reaches throughout the summer of 2002, with additional episodic releases during storms in the following winters. Suspended-sediment concentrations and loads at five continuously monitored turbidity and discharge gaging stations were estimated using regression methods. Deposition in salmonid spawning beds was measured using infiltration bags. Stations were located upstream and downstream of Cougar Reservoir in the South Fork McKenzie River, in the mainstem of the McKenzie River upstream of the South Fork and downstream of Blue River, and in Blue River downstream of Blue River Reservoir. During 2002, Cougar Reservoir released approximately 17,000 tons of suspended sediment into the South Fork McKenzie River, or more than twice the incoming load from the South Fork upstream of the reservoir. In 2003 and 2004, the release of sediment from Cougar Reservoir decreased to 10,900 and 4,100 tons, respectively. Although Cougar Reservoir likely was a substantial source of sediment to the lower reaches during water years 2002 and 2003, the lack of continuous turbidity monitoring at stations other than the South Fork McKenzie River prior to January 2003 prevents quantification of the actual contribution to the mainstem. During water year 2004, the only year with complete records at all sites, Cougar Reservoir released about 24 percent (4,100 tons) of the sediment load estimated on the mainstem near Vida (16,900 tons); however, the relative contribution of Cougar Reservoir is expected to have been substantially larger during 2002 and 2003 when the newly exposed river channel in the upper reaches of the reservoir was actively eroding and migrating.
\end{abstract}

\author{
Deposition of fine (less than 0.063-millimeter diameter) \\ sediment into spawning beds, measured with the use of \\ deployed infiltration bags, was greatest downstream of \\ Cougar and Blue River Reservoirs (1.0 and 1.2 percent of \\ total sediments, respectively). Deposition was least in the \\ high-energy, unregulated environments (about 0.25 percent) \\ of the South Fork McKenzie River above Cougar Reservoir \\ and in the mainstem above the South Fork, and intermediate \\ near Vida, the most downstream site on the mainstem. DDT, \\ applied throughout much of the upper McKenzie River \\ drainage basin to control spruce budworm during the 1950s, \\ was detected in the South Fork near Rainbow in the form of \\ its metabolites DDD and DDE in fine sediment captured in \\ the infiltration bags. DDE also was detected in infiltration \\ bags deployed in the McKenzie River near Vida, downstream \\ of the South Fork. All concentrations of DDD and DDE were \\ less than the aquatic-life criterion for bed sediment. DDT \\ species were not detected in water samples, including samples \\ collected during large storms. The reservoir apparently acted \\ as a trap for sediment and DDT throughout the course of its \\ existence, facilitating degradation of the trapped DDT, and \\ may have been a source for both during the construction \\ period in 2002-05, but the lack of detections during storms \\ indicates that DDT transport was small. Transport of \\ detectable amounts of DDT likely was limited to periods \\ of high suspended-sediment concentrations (greater than \\ 75-100 milligrams per liter). Infiltration bags were deployed \\ during August 2003-July 2004 and were a useful device for \\ measuring fine-sediment deposition and for chemical analysis \\ of the deposited material. Deposition of fine-grained sediment \\ downstream of the flood-control dams may be reduced if \\ bed-moving events can be periodically reintroduced to those \\ reaches.
}




\section{Introduction}

The McKenzie River originates in the High Cascades geologic province and flows westward through the Western Cascades (McKee, 1972; Tague and Grant, 2004) before reaching its confluence with the Willamette River near the cities of Springfield and Eugene, Oregon. Located on the South Fork McKenzie River, Cougar Reservoir is one of two large flood-control reservoirs in the basin operated by the U.S. Army Corps of Engineers (USACE) (fig. 1). In order to adhere to water-temperature requirements for salmonids in the South Fork McKenzie River and downstream on the mainstem McKenzie River, a construction project began in February 2002 to modify the reservoir's control tower and intake structure to allow withdrawal from multiple depths (U.S. Army Corps of Engineers, 2003).

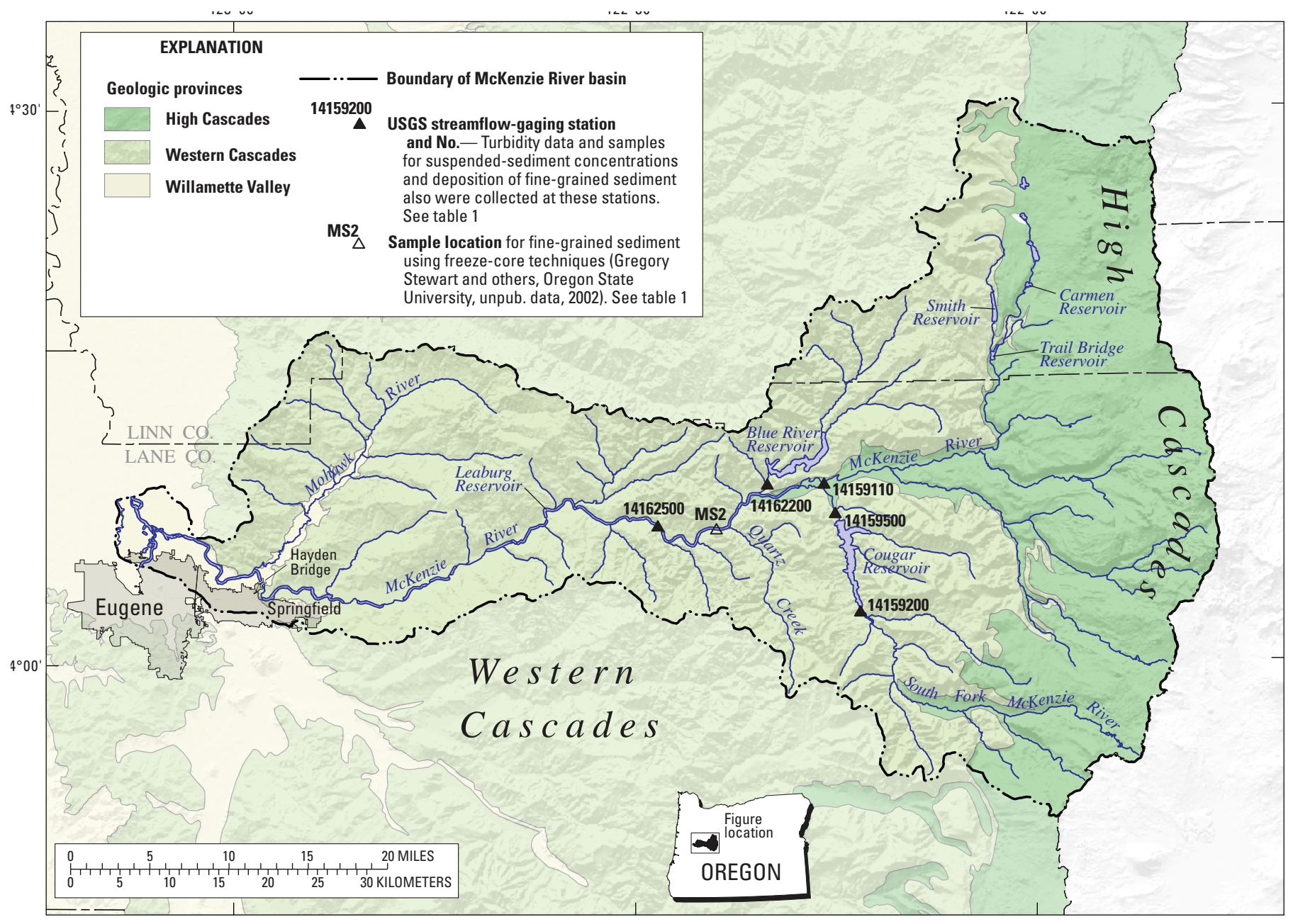

Basemap from USGS digital data sets $(1: 24,000$ and 1:500,000) UTM Zone 10, NAD27

Figure 1. Location of study area with sampling locations, McKenzie River basin, Oregon. 
The construction at Cougar Reservoir involved a drawdown of the reservoir pool to elevations well below (200-300 feet) its normal winter low-pool level (fig. 2) (U.S. Army Corps of Engineers, 2003). On February 23, 2002, a diversion tunnel beneath the dam was reopened, and beginning April 1, 2002, the reservoir's pool elevation was lowered. The pool remained at a lowered elevation until December 2004, at which point construction was complete and the reservoir began to refill and resume normal winter operations. Additional details on the construction are provided by the U.S. Army Corps of Engineers (2003).

As a result of the initial drawdown, several miles of the upper reaches of the reservoir pool were exposed to erosion from scouring flows during rainstorms, beginning in spring 2002 (U.S. Army Corps of Engineers, 2003) and continuing until completion of the project in December 2004. Deltaic sediments that had been deposited over almost 40 years of previous reservoir operation were thus subject to mobilization and downstream transport. The resulting elevated turbidity in downstream reaches of the South Fork (fig. 3) and mainstem of the McKenzie River caused increased local concern for potential negative effects on aquatic biota, including degradation of salmonid spawning habitat, from deposited sediments (U.S. Army Corps of Engineers, 2003). Additionally, the drinking-water facility for the city of Eugene, which draws its water from the McKenzie River, reported increased treatment costs when turbidities were elevated (K. Morgenstern, Eugene Water and Electric Board, written commun., 2002).

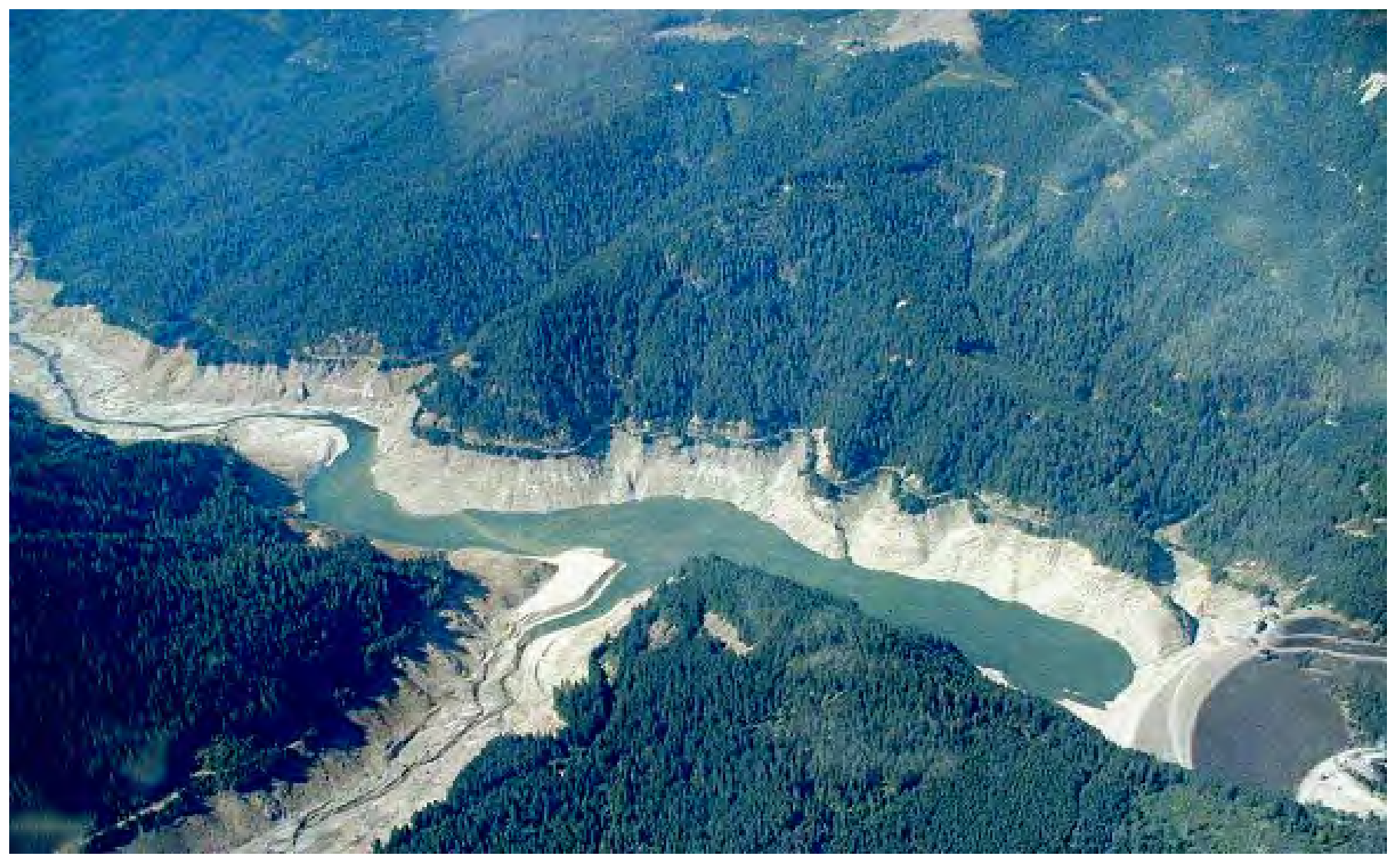

Figure 2. Aerial view of Cougar Reservoir during drawdown, with exposed upstream deltaic sediments, during the summer of 2002. (Photograph taken by U.S. Army Corps of Engineers, Portland District, Oregon, 2002.) 


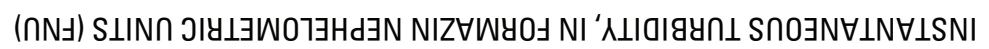

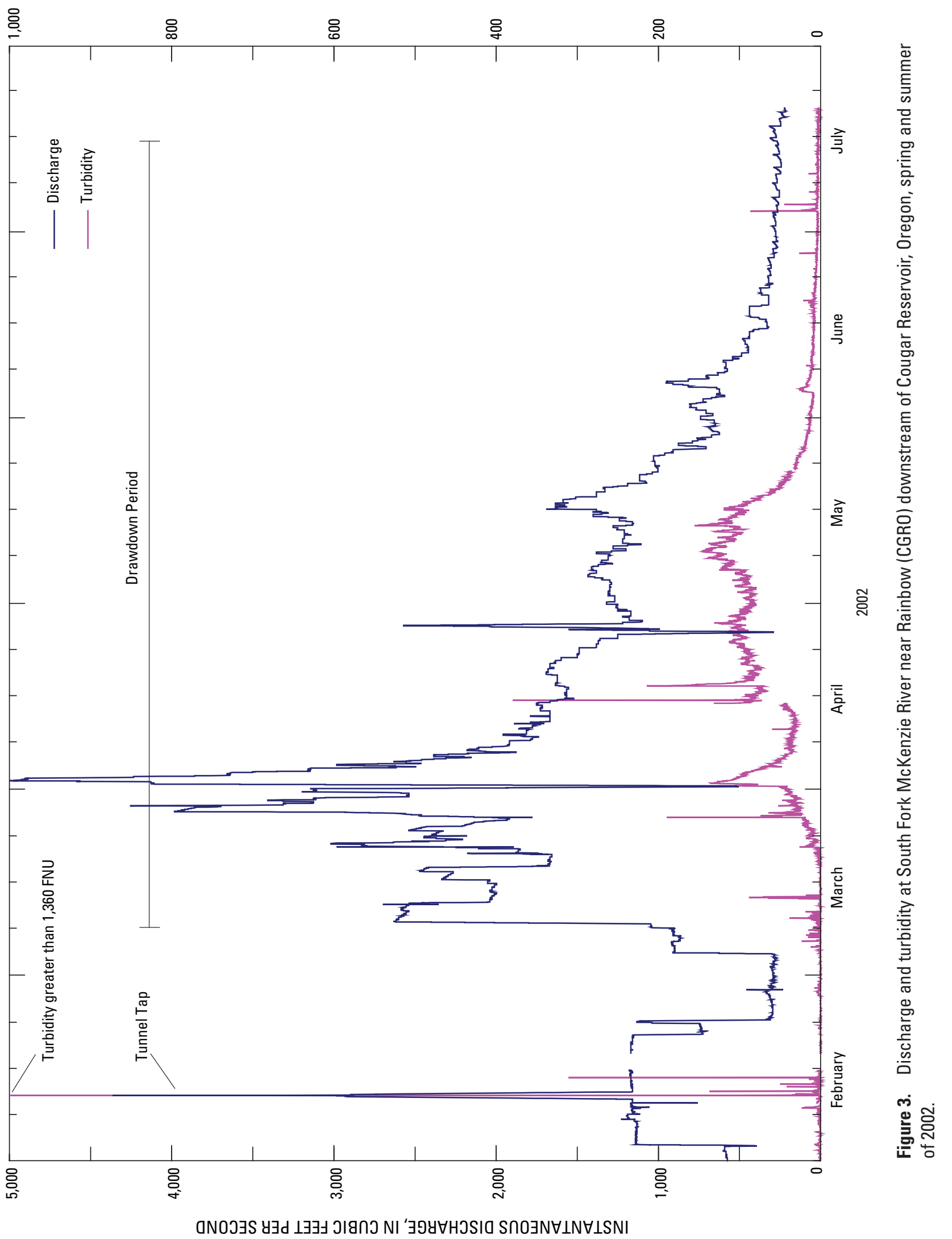


Turbidity is defined as an expression of the optical properties of a liquid that causes light rays to be scattered and absorbed rather than transmitted in straight lines through a sample (ASTM International, 2003). Turbidity is caused by the presence of suspended and dissolved matter, such as clay, silt, finely divided organic matter, plankton and other microscopic organisms, organic acids, and dyes (Anderson, 2004). Although not strictly a measure of particle concentration, turbidity commonly is used as a surrogate for suspended-sediment concentration (SSC), obtained by using locally derived regressions (Lewis, 1996; Sun and others, 2001; Gray and Glysson, 2003), often with relatively robust results. Recently, the use of logging turbidimeters that can be deployed in streams to obtain a record of nearly continuous turbidity, together with discharge and site-specific regressions between turbidity and SSC, has allowed the estimation of nearly continuous concentrations and loads of suspended sediment (Christensen and others, 2000; Uhrich and Bragg, 2003).

Initial transport of suspended sediment during 2002 was estimated by Grant and others (2002) and the U.S. Army Corps of Engineers (2003) using relations between turbidity and SSC developed for the adjacent North Santiam River basin (Uhrich and Bragg, 2003). Nearly continuous (half-hourly) turbidity data were available, beginning in 2000, at gaging stations in the South Fork McKenzie River immediately upstream and downstream of Cougar Reservoir. However, only a few SSC samples with concurrent turbidity readings were available from these two stations, and it was unclear to what extent turbidity-SSC relations that had been developed for the North Santiam River were directly transferable to the McKenzie River basin.

Adding to local concerns about effects on aquatic biota, the USACE determined through routine testing that sediment from the reservoir and surrounding upland soils and downstream bank sediments was contaminated with low to moderate concentrations of the legacy organochlorine pesticide dichloro-diphenyl-trichloroethane (DDT) and its metabolites, dichloro-diphenyl-dichloroethane (DDD) and dichloro-diphenyl-dichloroethylene (DDE) (the sum of these terms is henceforth referred to as $\Sigma D D x$ ) (U.S. Army Corps of Engineers, 2003). The source for $\Sigma$ DDx was presumed to be residual from forest spraying of DDT in the 1950s and 1960s to control spruce budworm and other pests in the South Fork and much of the upper McKenzie River drainage basins (Dolph, 1980; Moore and Loper, 1980). It was unknown to what extent this $\Sigma$ DDx was being mobilized and transported downstream with the elevated suspended sediment following the reservoir drawdown and construction; however, there was concern that the $\Sigma$ DDx could be sorbed to fine sediment and deposited in salmonid spawning areas, potentially harming developing fry.
On the basis of these concerns, the U.S. Geological Survey (USGS) was asked to help the USACE determine the contribution of sediment from the Cougar Reservoir drawdown and construction project to downstream sediment transport and deposition during 2002-04, including the potential for transport and deposition of $\Sigma \mathrm{DDx}$.

\section{Purpose and Scope}

This report presents the results of the 2002-04 cooperative USACE-USGS study. Estimated suspendedsediment loads are mass balanced to evaluate overall sources and sinks in the McKenzie River from the South Fork down to the Vida reach, and the role of the construction project at Cougar Reservoir on downstream sediment transport and deposition. The report also evaluates the effect of the construction on transport of $\Sigma \mathrm{DDx}$ in water and deposition in fine sediment downstream of Cougar Reservoir.

Turbidity data used in the estimation of continuous SSC were collected from five stations on the South Fork McKenzie, Blue River, and mainstem McKenzie River and were previously published (U.S. Geological Survey, 2002, 2003, 2004). Individual sample data on SSC and $\Sigma$ DDx, and deposition of fine sediment and $\Sigma D D x$, are presented in this report, along with daily loads of SSC as estimated from the product of site-specific regressions of turbidity and SSC, and discharge.

\section{Approach}

The approach for this study was to determine locally specific relations between turbidity and SSC and, where possible, use those relations to estimate instantaneous SSC concentrations, using hourly turbidities at selected monitoring locations in the basin. During a few high-flow events, suspended sediment was analyzed for $\Sigma \mathrm{DDx}$ to determine if it was being transported and if additional sampling was warranted. Deposition of fine sediment in spawning gravels was estimated using infiltration bags, as described by Lisle and Eads (1991), modified to allow subsampling for organic contaminants such as DDDx, and deployed from August 2003 to July 2004. For this report, the fine-fraction of sediment is defined as silt and clay particles having a diameter of less than 0.063 millimeter $(\mathrm{mm})$.

\section{SSC and Turbidity Relations}

In the McKenzie River basin, turbidity data were collected continuously in the South Fork McKenzie River at stations upstream and downstream of Cougar Reservoir beginning in December 2000. Additional turbidity-monitors 
were installed in January 2003 on the McKenzie River above South Fork McKenzie River, near Rainbow; Blue River at Blue River downstream of Blue River Reservoir, and the McKenzie River near Vida downstream of all other stations (fig. 1, table 1). All turbidity-monitors were collocated with preexisting streamflow stations, or in one case installed concurrently with streamflow instrumentation, and the data were published annually (U.S. Geological Survey, 2000, 2001, 2002, 2003, 2004). However, suspended-sediment samples were collected only sporadically during the drawdown period in 2002, and the number of samples was insufficient to perform a statistically significant SSC-turbidity regression. Suspended-sediment sampling was initiated at all five gaging stations in January 2003 and continued through May 2004. Data collected was used to develop site-specific relations between turbidity and SSC.

The role of Cougar Reservoir in transporting suspended sediment downstream raises questions about the larger role of streamflow regulation in the basin. Other reservoirs in the McKenzie River system include, from the headwaters moving downstream, the Eugene Water and Electric Board (EWEB) hydroelectric facilities at Trail Bridge Reservoir, at the mouth of the Smith River at about river mile (RM) 81.9, and Carmen Smith Reservoir, about 2 miles (mi) upstream on the Smith River. The South Fork joins the McKenzie River at RM 59.7, just upstream of Blue River (RM 57.0), with Blue River Reservoir located 1.7 mi upstream on Blue River. Farther downstream of the South Fork, EWEB also operates Leaburg Reservoir (RM 38.8), which is primarily a diversion structure for additional power-generation facilities in the lower river. Of these water bodies, the flood-control reservoirs (Cougar and Blue River) experience the largest annual poolelevation fluctuations under normal operating conditions, as pool levels are drawn down 100-200 feet (ft) in winter in order to accommodate large winter storms, and residence times are on the order of 3-4 months (Johnson and others, 1985). The reservoir pools at Trail Bridge and Carmen Smith hydroelectric facilities may have moderate, frequent changes in pool elevations (5-12 ft) but are largely designed to let large flows pass through them with minimal effect.

From the standpoint of flow regulation, therefore, Cougar and Blue River Reservoirs have a much larger effect on the hydrology of the McKenzie River than do Carmen Smith and Trail Bridge Reservoirs. In this report, "regulated" sites are those directly downstream of flood-control reservoirs; the South Fork McKenzie River near Rainbow (CGRO), located downstream of Cougar Reservoir and Blue River at Blue River (BLUE). Unregulated sites, which also serve as reference sites for evaluation of sediment transport and deposition, are those that are completely or almost unaffected by reservoir operation, including the South Fork McKenzie River above Cougar Reservoir, near Rainbow (SFCO) and the McKenzie River above the South Fork, near Rainbow (MRBO). The status of the McKenzie River near Vida (VIDA), downstream of the mouths of Blue River and the South Fork McKenzie River, is evaluated separately for the differential effects of regulation by the upstream flood-control reservoirs (Blue River and Cougar Reservoirs) on flow and suspendedsediment concentrations.

Table 1. Stations used to monitor discharge, turbidity, and sediment in the McKenzie River basin, Oregon, $2002-04$.

[Locations of USGS stations shown in figure 1. Percent complete instantaneous turbidity record is determined from beginning of water year 2002 or from date of installation, whichever was later. Abbreviations: USGS, U.S. Geological Survey. -, no data]

\begin{tabular}{|c|c|c|c|c|c|}
\hline \multirow{2}{*}{$\begin{array}{l}\text { USGS } \\
\text { station No. }\end{array}$} & \multirow{2}{*}{ Station name } & \multirow{2}{*}{$\begin{array}{l}\text { Reference } \\
\text { name }\end{array}$} & \multicolumn{2}{|c|}{ Period of record } & \multirow{2}{*}{$\begin{array}{c}\text { Percent } \\
\text { complete } \\
\text { turbidity } \\
\text { record }\end{array}$} \\
\hline & & & Discharge & Turbidity & \\
\hline 14159110 & $\begin{array}{l}\text { McKenzie River above South } \\
\text { Fork, near Rainbow }\end{array}$ & MRBO & Jan. 2003-Sept. 2004 & Jan. 2003-Sept. 2004 & 97.9 \\
\hline 14159500 & $\begin{array}{l}\text { South Fork McKenzie River near } \\
\text { Rainbow }\end{array}$ & CGRO & Oct. 1947-Sept. 2004 & Dec. 2000-Sept. 2004 & 95.0 \\
\hline 14162200 & Blue River at Blue River & BLUE & Feb. 1966-Sept. 2004. & Jan. 2003-Sept. 2004 & 84.8 \\
\hline 14162500 & McKenzie River near Vida & VIDA & Sept. 1924-Sept. 2004 & Jan. 2003-Sept. 2004 & 93.8 \\
\hline
\end{tabular}




\section{Deposition}

Deposition of fine-grained sediment released from Cougar Reservoir into spawning gravels also was a concern following reservoir drawdown. Fine sediment can clog pore spaces in the streambed, decreasing subsurface flow (Brunke and Gonser, 1997) and potentially decreasing the dissolved-oxygen (DO) concentration in the pore water. Such a decrease in pore-water DO concentration could negatively affect developing eggs of salmonids (Meyer, 2003), such as those present in the McKenzie River basin, including several threatened or endangered species. Additionally, the potential that deposited fine sediment could be contaminated with residual DDT or its metabolites from historical spraying practices caused additional concern for toxicity to salmonid larvae as they developed within the spawning gravels.

During the summer of 2002 immediately following the drawdown, Gregory Stewart and others (Oregon State University, unpub. data, 2002) used freeze-core techniques to sample for fine-grained sediment throughout a depth of $0-40$ centimeter $(1.3 \mathrm{ft})$ in spawning gravels at approximately the same five locations upstream and downstream of Cougar Reservoir and in the mainstem McKenzie River as sampled for this study. The freeze cores allow the examination of native, undisturbed sediment in "gravel popsicles," including profiles with depth. Although the freeze cores provide an indication of the total amount of recent and historical sediment deposition at a site, they do not by themselves provide a means to interpret the time frame of deposition or estimate recent deposition. Data from the freeze cores indicated an increased percentage of fine sediment in cores collected downstream of Cougar and Blue River Reservoirs; however, only the middle $20 \mathrm{~cm}$ of the cores could be used because of downstream sloughing or erosion of fine materials around the perimeter of the frozen core cylinder, primarily in the top and bottom $10 \mathrm{~cm}$, upon removal of the core from the streambed. The freeze-coring technique also did not allow subsampling for analysis of contaminants within the sediment matrix.

As a result of the unknowns remaining following the freeze-core sampling, infiltration bags (Lisle and Eads, 1991) were used during 2003-04 to discern the effect of Cougar Reservoir release of fine sediment on deposition in spawning gravels. The infiltration bags involved the burial of a collapsed bag under experimental bed material (gravel or cobbles that approximate the native material) for a defined period of time. During retrieval, the bag was extended upward past the sediment surface, capturing the entire column of sediment. This technique allows for collection of fine sediment throughout the depth of the buried infiltration bag, mimicking the sediment-accumulation processes in a native streambed, and for extrapolation to an overall deposition rate given the known period of deployment; however, no information on historical deposition rates can be learned from them. In this study the infiltration bags were modified to allow clean sampling for DDT and metabolites associated with the fine sediment in the bags. Specific methods are described in the section, "Methods."

\section{Methods}

Turbidity data and samples for suspended-sediment concentrations were collected from streamflow-gaging stations (Rantz and others, 1982; Edwards and Glysson, 1999; Wagner and others, 2006) as indicated in table 1. Records for continuous turbidity were longer for two stations on the South Fork McKenzie River because those turbidimeters were installed during 2000, prior to the construction and drawdown at Cougar Reservoir. Turbidimeters were installed at the other three stations in January 2003, resulting in relatively complete data sets for water years 2003-04 but no data during the initial drawdown period at those stations.

\section{Turbidity Monitoring}

Turbidity was monitored according to standard USGS protocols (Wagner and others, 2006). All turbidimeters installed in the McKenzie River basin used near-infrared light sources, with a single detector at 90 degrees to the incident light beam. On the basis of this configuration, turbidity data are reported in Formazin Nephelometric Units (FNU), as specified for USGS (Anderson, 2004). This reporting unit provides traceability and specificity to the instruments used to make the measurements, helping to reduce uncertainty in data analysis. Although FNUs may be considered equivalent to the more traditional Nephelometric Turbidity Unit (NTU), direct comparison with data from instruments with optical configurations different from FNU should be done with caution and only if compatibility can be demonstrated among the instruments used. The turbidimeters used were SDI-12 compatible Analite ${ }^{\odot} 395$ probes from McVan Instruments Pty Ltd, except at the South Fork McKenzie River above Cougar Reservoir prior to 2003, when an analog Analite $^{\odot} 195$ probe was used. The Analite ${ }^{\odot} 195$ and 395 probes differ only in signal processing but use identical optics so they provide data that are directly comparable. During sediment sampling, YSI 6920 Multiparameter Sondes equipped with model 6026 turbidity probes were used for instantaneous readings and cross-sectional profiling of turbidity. The 6026 probe also was manufactured by McVan Instruments, and recent work has shown a near 1:1 comparison between the Analite ${ }^{\odot} 195$ and YSI 6026 turbidity probes (H.M. Bragg, U.S. Geological Survey, unpub. data, 2004). 
Turbidity data were recorded every 15 or 30 minutes, depending on the station. Except for data from the analog Analite $^{\odot} 195$ probe, which were instantaneous readings, values were reported as the median of 100 readings during a period of about 1 minute. Signal processing in this manner, which is a feature of the Analite ${ }^{\odot}$ probes used, helps to reduce the high variability that is common for turbidity data. For the purposes of estimating suspended-sediment concentrations, values during periods of missing data typically were estimated as the general, recent background value at the individual station, typically less than $1 \mathrm{FNU}$, unless changes in discharge or other information indicated the likelihood of increased turbidity. If increased turbidity was indicated where data were missing, turbidity values were not estimated. Turbidity records typically were greater than (>) 94 percent complete, except at BLUE. Most of the missing data from BLUE was during a 3-month period in late summer 2004 and was therefore not significant relative to sediment transport.

\section{Suspended Sediment}

Samples for suspended-sediment concentration (SSC) were collected using standard USGS methods for depth- and width-integrated (EWI) sampling (Edwards and Glysson, 1999), except where otherwise noted. Samples were collected from cableways, if available, or otherwise from bridges, by using a USGS D-74 sediment sampler with pint glass bottles, suspended with a B-reel (Edwards and Glysson, 1999). Cableways were used at CGRO, BLUE, and VIDA, whereas bridges were used at MRBO and SFCO; a bridge about $1.5 \mathrm{mi}$ downstream of CGRO also was used on occasion. SSC samples were analyzed at the USGS Sediment Laboratory in Vancouver, Washington. Samples were analyzed gravimetrically, and data reported in milligrams per liter of dried sediment and the percentage of SSC in the fine fraction, defined as having a median diameter less than $(<) 0.063 \mathrm{~mm}$.

In some cases, samples were collected by grab sampling, typically during storm events where conditions were rapidly changing and many sites were being sampled in a short amount of time. Grab sampling typically was accomplished by use of a weighted container holding a sample bottle and suspended by rope from a bridge. These samples typically approximated EWI sampling because they were collected from multiple locations in a transect across the bridge. Evaluation of SSC data from CGRO and BLUE indicated that the fraction of fine sediments typically was equal to or greater than
90 percent (medians 93 and 90 percent, respectively). Fine sediment typically does not settle rapidly in flowing water. Because of the high percentage of fine material, sediment concentrations in the cross sections were assumed to be well mixed, and the use of grab samples at CGRO and BLUE therefore was considered to be an acceptable method when time constraints prevented more thorough EWI sampling.

\section{Calculations}

Regressions of SSC with turbidity (taken at the time of SSC sample collection) were calculated individually for each station. Regression equations are given as a power function in the format $\mathrm{y}=\mathrm{bx}^{\mathrm{a}}$, where $\mathrm{y}$ is SSC, in millgrams per liter, $\mathrm{x}$ is the reported instantaneous turbidity, in FNU, and $\mathrm{b}$ and $\mathrm{a}$ are regression coefficients. This is equivalent to an ordinary least-squares regression on the log-transformed values of SSC and turbidity. Such relations have been used increasingly as a means of predicting SSC from continuous turbidity probes (Christensen and others, 2000; Gray and Glysson, 2003; Uhrich and Bragg, 2003).

For each station, computed estimates of suspendedsediment load (SSL) were based on continuous turbidity and discharge records for individual sites. Regression equations (see above) for turbidity-SSC relations were used to compute SSC from the instantaneous turbidity values at each site, after correcting for transformation bias by using Duan's smearing estimate (Helsel and Hirsch, 1992). For each regression, the model standard prediction error (MSPE) was calculated from the Mean Square Error (MSE) of the regression (Patrick P. Rasmussen and others, U.S. Geological Survey, written commun. 2007) as

$$
+\mathrm{MSPE}=\left[10^{\wedge}(\mathrm{MSE})-1\right]^{*} 100
$$

and

$$
-\mathrm{MSPE}=\left[10^{\wedge}(-\mathrm{MSE})\right]^{*} 100 .
$$

The computed SSC, in milligrams of suspended sediment per liter, was multiplied by discharge for each 30-minute interval, with a unit conversion, to determine SSL for the respective intervals, in tons of sediment transported per day. The resulting 48 daily values of SSL were averaged to produce a daily mean estimate of SSL. Annual sediment load, in tons per year, was determined by summing the 365 daily mean estimates. 


\section{Analysis of DDT in Suspended Material}

Using reconnaissance data collected by the U.S. Army Corps of Engineers (2003) on $\Sigma$ DDx in exposed reservoir and streambank sediments, a coarse calculation was made to estimate the amount of suspended material needed in order to detect $\Sigma \mathrm{DDx}$ in transport, and thereby to estimate the minimum turbidity needed to be able to detect $\Sigma$ DDx in the water column. The USEPA criterion for the protection of aquatic life for $\Sigma$ DDx is 0.001 micrograms per liter $(\mu \mathrm{g} / \mathrm{L})$, which commonly is the analytical detection limit for many laboratories. The median $\Sigma$ DDx concentration in bed sediment in the exposed reservoir and streambank sediments was 13.6 micrograms per kilogram $(\mu \mathrm{g} / \mathrm{kg}$ ) (U.S. Army Corps of Engineers, 2003). Therefore, and accounting for unit conversion,

$$
\begin{aligned}
& \mathrm{SSC}(\mathrm{mg} / \mathrm{L})=\frac{(0.001 \mu \mathrm{g} / \mathrm{L}) \times\left(10^{6} \mathrm{mg} / \mathrm{kg}\right)}{(13.6 \mu \mathrm{g} / \mathrm{kg})}, \\
& \text { or } \\
& \mathrm{SSC}=73.5 \mathrm{mg} / \mathrm{L} .
\end{aligned}
$$

Using a preliminary equation for SSC as a function of turbidity from a lower basin site in the North Santiam River as a starting point, where turbidities generally are less than 200 FNU (H.M. Bragg, U.S. Geological Survey, written commun., 2002), a threshold turbidity value of about 100 FNU was used as a target for conditions that would trigger sampling for $\Sigma$ DDx in suspended material. In order to increase detectability by increasing the mass of sediment analyzed, $\Sigma D D x$ was analyzed separately from the suspended and dissolved phases for some samples.

In order to maintain clean sampling techniques, sampling for $\Sigma$ DDx was conducted with Teflon ${ }^{\circledast}$ sampling equipment, which was cleaned as specified by Wilde (2004) for organic constituents. Depth- and width-integrated samples for suspended sediment were collected using a D-95 sampler (McGregor, 2000) equipped with a 1-L Teflon ${ }^{\circledR}$ bottle and Teflon ${ }^{\circledR}$ cap and nozzle assembly. Subsamples from individual verticals in the cross section were composited into 3-L Teflon ${ }^{\circledast}$ bottles, and stored on ice until they could be processed in the laboratory, a period of less than 8 hours. Additional 3-L Teflon ${ }^{\circledR}$ bottles for equipment rinses were filled by grab sampling at the side of the river, as necessary. In the laboratory, all 3-L Teflon ${ }^{\circledR}$ sample bottles for each site were composited into a 14-L Teflon ${ }^{\circledR}$ churn splitter (Horowitz and others, 2001), and whole-water (unfiltered) subsamples were drawn for SSC and suspended organic carbon. Subsequently, samples for organochlorine pesticides including $\Sigma$ DDx were filtered directly from the churn splitter through baked glassfiber filters (0.7-micron nominal pore size) housed in an aluminum filtration apparatus, using ceramic-piston metering pumps equipped with Teflon ${ }^{\circledast}$ tubing. The glass-fiber filters were retained for analysis of organochlorine pesticides in the suspended material, and the filtrate was collected into baked, amber glass, 1-L pesticide bottles, with the volume of water filtered noted. Dissolved organic carbon (DOC) was processed according to standard USGS protocols (Wilde and others, 1999; 2004). For some samples, whole-water samples were submitted for analysis when separation into dissolved and suspended partitions was not practical.

Laboratory analyses of $\Sigma D D x$ in suspended sediment were performed by Severn-Trent Laboratory, in Seattle, Washington, in accordance with standard organochlorine analysis by U.S. Environmental Protection Agency (USEPA) SW-846 method 8081A. DOC was analyzed according to USEPA method SW-906. Quality-assurance data indicated acceptable data quality for organochlorine analysis, with nondetect values reported for all blank results (Method Detection Limit $(\mathrm{MDL})=0.0022 \mu \mathrm{g} / \mathrm{L}$. For analysis of DOC, a field blank using certified, organic-free water in April 2003 was reported as 1.8 milligrams per liter $(\mathrm{mg} / \mathrm{L})$, with an MDL of $0.5 \mathrm{mg} / \mathrm{L}$.

\section{Sediment Deposition}

Infiltration bags were deployed in August 2003 in spawning gravels corresponding to each of the dischargeand turbidity-monitoring stations (table 1), and retrieved in July 2004. Bags were deployed in triplicate, arranged at least 5-7 ft apart in a direction orthogonal to surface flow lines at the individual site to avoid interactions of sediment dynamics between the individual bags. Sites were selected with assistance from fishery biologists from Oregon State Department of Fish and Wildlife, and on the basis of known spawning use by salmonids, with observable downwelling, moderate flow velocity, and for their relatively shallow overlying water depth. Shallow water $(4-10 \mathrm{~cm})$ was desired during low flow to minimize loss of fine sediment upon retrieval. 
The bags were constructed and deployed following the general dimensions provided by Lisle and Eads (1991), modified to allow for analysis of $\mathrm{DDDx}$ from the retrieved sample and to reduce erosion of surficial fine sediments by turbulence from overlying water during retrieval. Bags were made from a laminated vinyl fabric (14 mil), glued into a cylindrical shape (diameter $30 \mathrm{~cm}$, height $56 \mathrm{~cm}$, total volume 39.6 L) using a vinyl adhesive (HH-6, RH Products, Acton, $\mathrm{MA})$, with a metal hoop in the mouth to help the bag retain

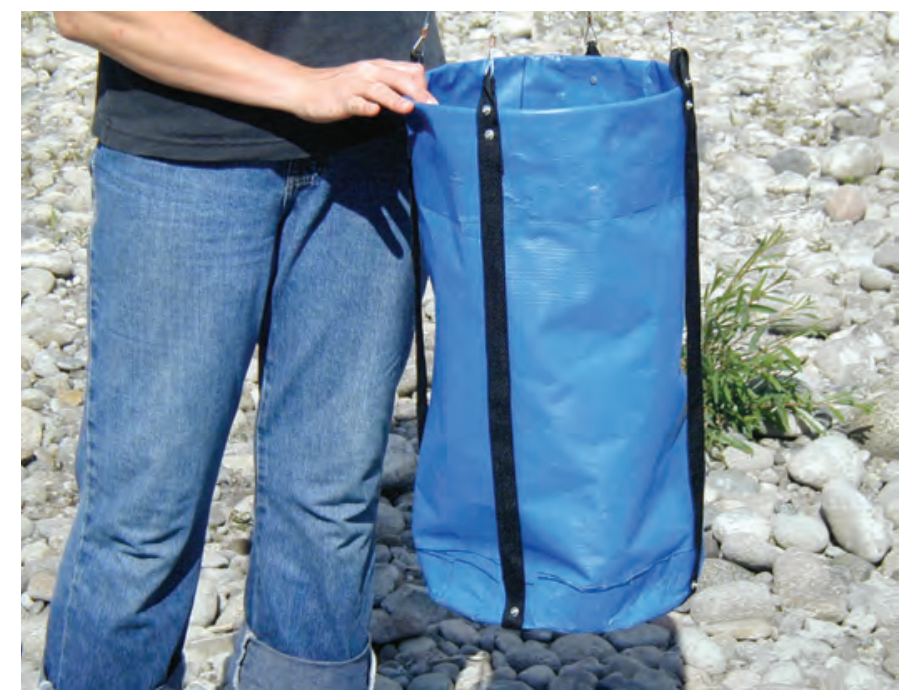

A. Constructed infiltration bag

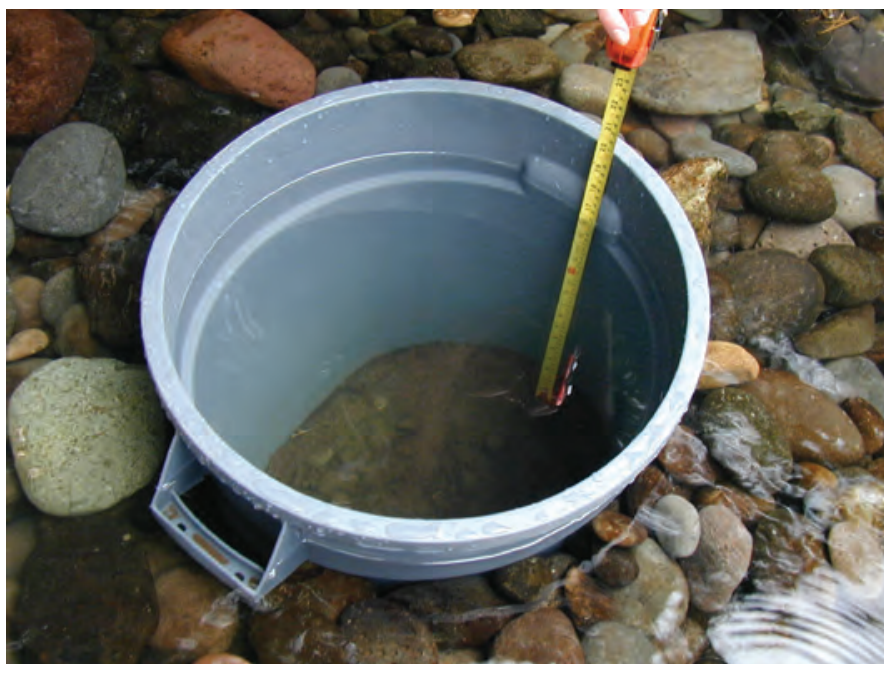

B. $40 \mathrm{~cm}$ deep hole in streambed inside solid form its cylindrical form. A 4-mil Teflon ${ }^{\circledR}$ bag (19.8 liter) was riveted into each infiltration bag to provide a clean interior for ¿DDx sampling. The infiltration bags were supported with nylon webbing straps, riveted at the mouth, bottom edges, and underneath, to hold the weight of river rocks and water when retrieved. Cables (1/8-inch steel, approximately 31 inches or $80 \mathrm{~cm}$ long) were attached to loops in the nylon webbing near the mouth of the bag for retrieval (fig. 4A).

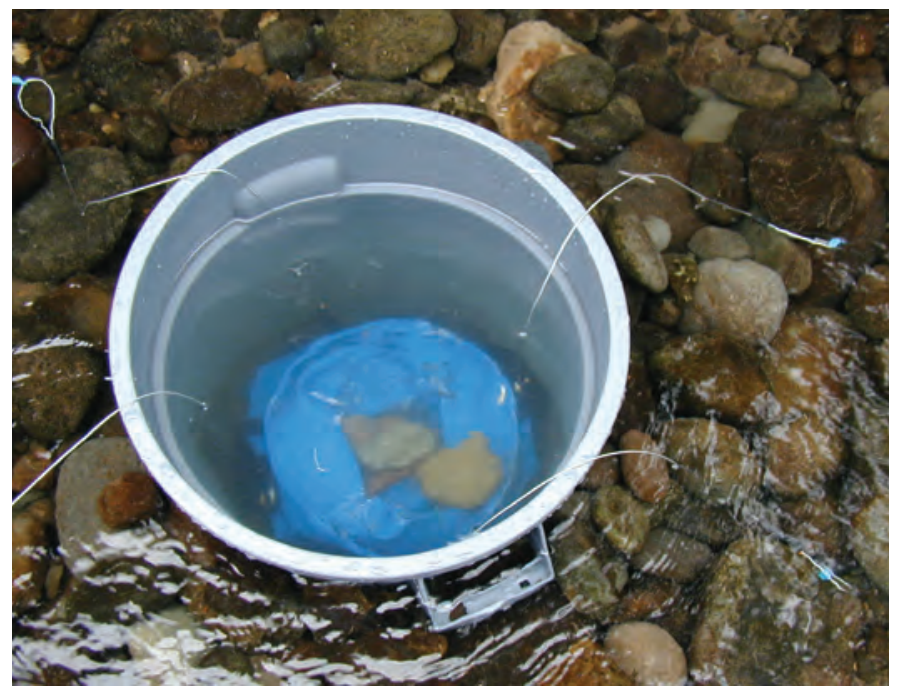

C. Collapsed bag with retrieval cables extending to the streambed surface

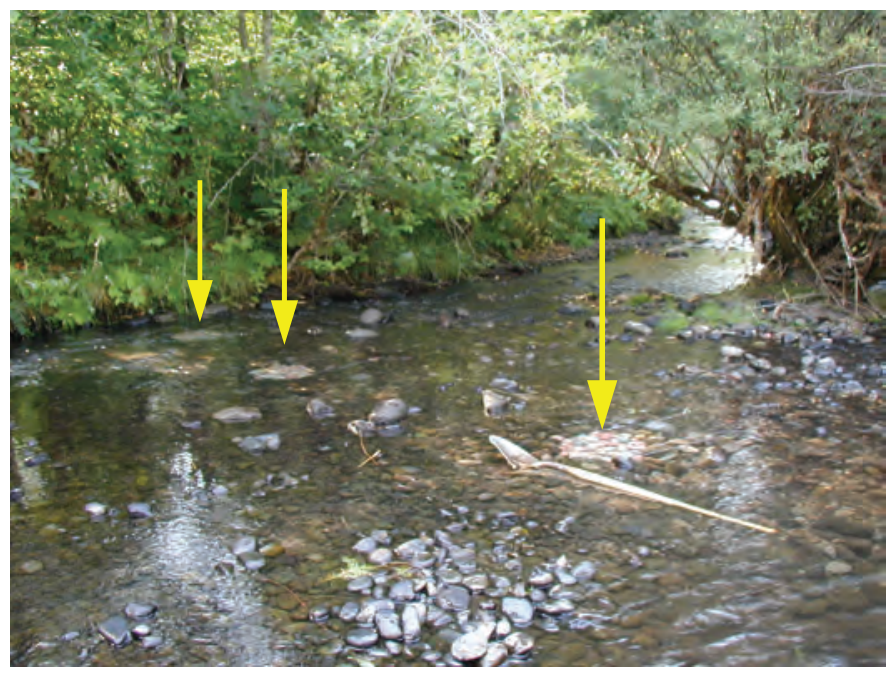

D. Three installed infiltration bags (arrows), with a shovel for scale

Figure 4. Installation process for infiltration bags for estimation of fine sediment deposition in the McKenzie River, Oregon. 
Prior to deployment of infiltration bags, the depth of water overlying the sediment was measured. Deployment involved the excavation of a 40-cm-deep hole in the streambed from inside an open, solid cylindrical form (fig. 4B).

To characterize the native bed material at each site, all surface rocks down to the armored layer were carefully removed and the diameter (intermediate-axis length) measured. Nearsurface rocks (including sand) were carefully extracted or shoveled into a bucket for later laboratory analysis of size fraction. Median diameters for native surface rocks among all sites ranged from about 3 to $7 \mathrm{~cm}$. This method did not, however, adequately capture or characterize native fine material in the bed, which was susceptible to resuspension and export during the digging process. Background stream turbidity was less than $1 \mathrm{FNU}$ at all sites at the time of deployment. After excavating the hole, the water was allowed to clear (5-10 minutes), at which point the bag was placed collapsed in the bottom of the hole with cables extending beyond the opening of the cylindrical form (fig. 4C). Experimental gravel (median diameter $5.0 \mathrm{~cm}$ ), which had been vigorously cleaned of fine materials using stream water immediately prior to deployment, was placed in the form on top of the collapsed bag and refilled to the original level of the streambed. Final depth of overlying water inside the form was measured, and then the form removed vertically, leaving the collapsed infiltration bag buried in place under $40 \mathrm{~cm}$ of experimental gravel (fig. 4D). The exposed lengths of the retrieval cables also were measured to allow estimation of aggradation or scour upon retrieval. To help locate the bags upon retrieval, all bag locations were mapped and global positioning system coordinates recorded.

Infiltration bags were extracted from the streambed during July 2004. Retrieval of the infiltration bags was accomplished by the use of a large tripod equipped with a winch, after initial measurements of the depth of overlying water and careful removal, measurement (intermediate axis length), and retention of any large cobbles or boulders that had been moved over the buried bags. The winch was connected to the four exposed retrieval cables for each bag, and hoisted slowly until the streambed began to visibly deform. Once deformation or erosion was visible, the cables were rapidly hoisted until the mouth of the bag extended beyond the sediment surface, whereupon it was immediately grabbed and the bag pulled up enough for the mouth to break the surface of the water to prevent erosion of surficial layers. At this point, it was considered a stable sample. The bag was subsequently pulled gently from the streambed, with the exterior rinsed to remove additional fine materials, and emptied into a large stainless steel receptacle that had been precleaned according to Wilde (2004). The initial depth of water in the receptacle was noted for calculations of the volume of bed material and overlying streamwater removed with the infiltration bag. The Teflon ${ }^{\circledR}$ liner was removed from the bag and carefully rinsed into the receptacle with certified organic-free water. Individually, each rock was removed from the receptacle, rinsed into it with organic-free water, and set aside for size analysis. Upon removal of all gravel-size and larger rocks, the remaining sediment was sieved to retain coarse silt and largersized particles $(>0.063 \mathrm{~mm})$ and removed for size-fraction analysis (fig. 5). The volume of all organic-free water used to rinse rocks or other sampling apparatus into the receptacle was carefully noted, as was the final depth of water in the stainless steel receptacle for final calculations of volume. Streamwater overlying the infiltration bags also was sampled (prior to extraction) for concentrations of suspended sediment, organic carbon, and organochlorine compounds.

The remaining slurry, consisting of pore water, surface water, organic-free water, and fine streambed sediment was transferred to a Teflon ${ }^{\circledR}$ churn splitter for subsampling. Whole-water subsamples were taken from the churn splitter for analysis of SSC, dissolved and suspended organic carbon (Wilde and others, 2004), and organochlorine compounds, including $\Sigma$ DDx, in both water and sediment, and the samples were chilled until they could be shipped to a laboratory.

Initially, $\Sigma D D x$ was to be analyzed by filtering the slurry through a baked glass-fiber filter $(0.7-\mu \mathrm{m}$ pore size $)$, and submitting both the filter with caked sediment and filtrate for separate analyses; however, the slurry was too thick to filter. Instead, whole-water samples in 1-liter (L) baked amber glass (GCC) bottles were submitted for analysis with the intention that the high sediment concentrations in the slurry would facilitate detection; however, an apparent laboratory contamination rendered these whole-water results unusable. Ultimately, archived 1-L samples of the slurry in GCC bottles were submitted to the laboratory (Severn-Trent, Seattle, Wash.), where they were centrifuged to separate sediment from water and analyzed in accordance with USEPA SW-846 method $8081 \mathrm{~A}$. The resulting supernatant water was analyzed according to USEPA SW-846 method 3510C, and fine sediment according to USEPA SW-846 method 3550B. These archived samples were about 5 months old when submitted to the laboratory and therefore exceeded the accepted holding time for the method; however, they had been refrigerated since sampling, and degradation of organochlorine compounds in the archived samples during holding was believed to be minimal so analysis was still worthwhile. This extended holding time is considered for all interpretations of results for the organochlorine analyses from infiltration bags. 


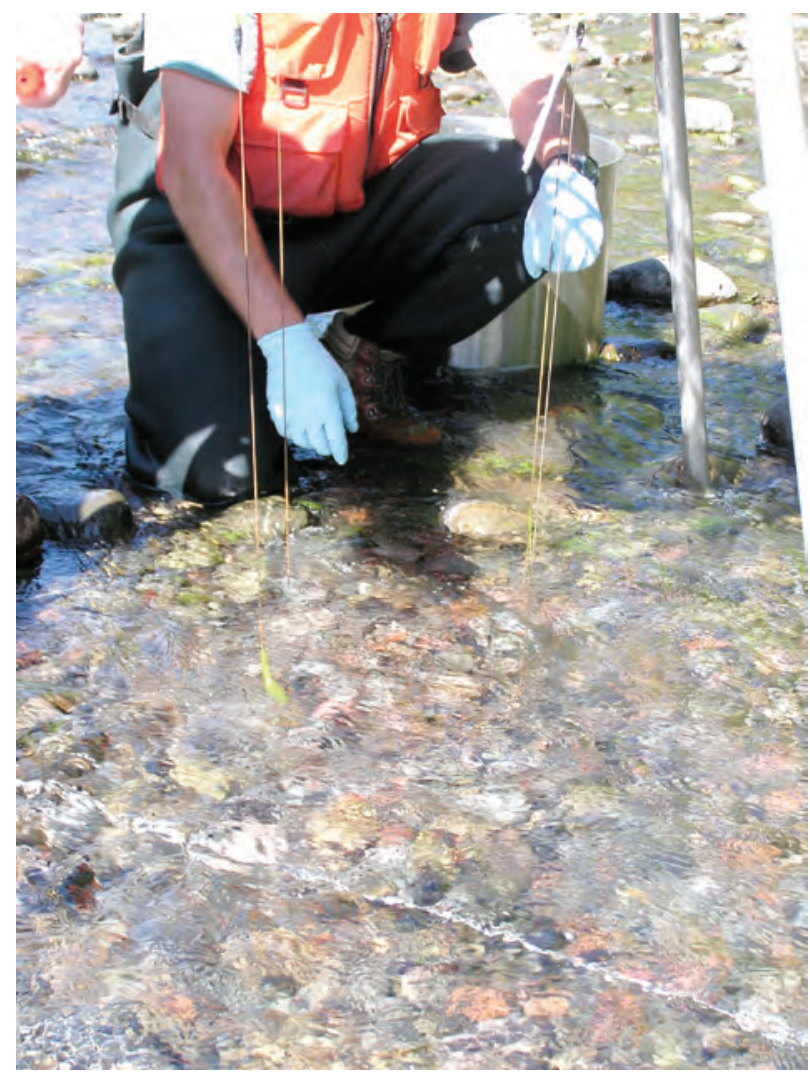

A. Tightened retrieval cables, with slight deformation of bed surface evident

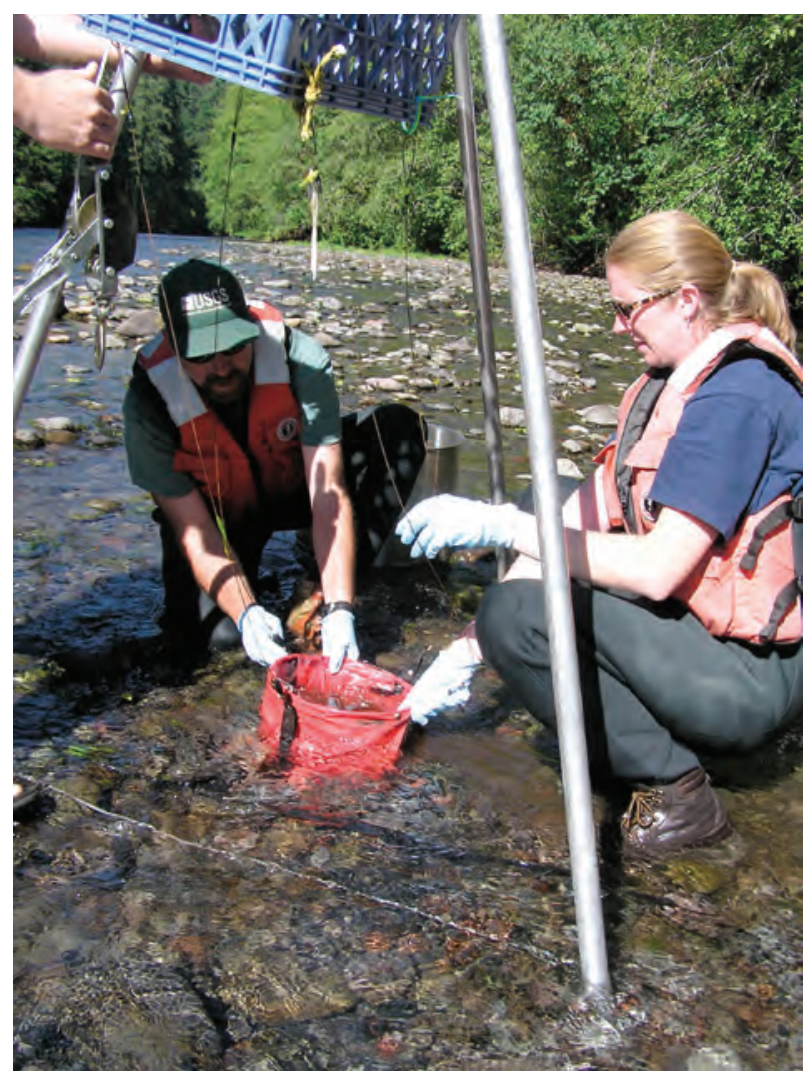

B. Partly extracted bag with mouth extending beyond water surface to prevent erosion

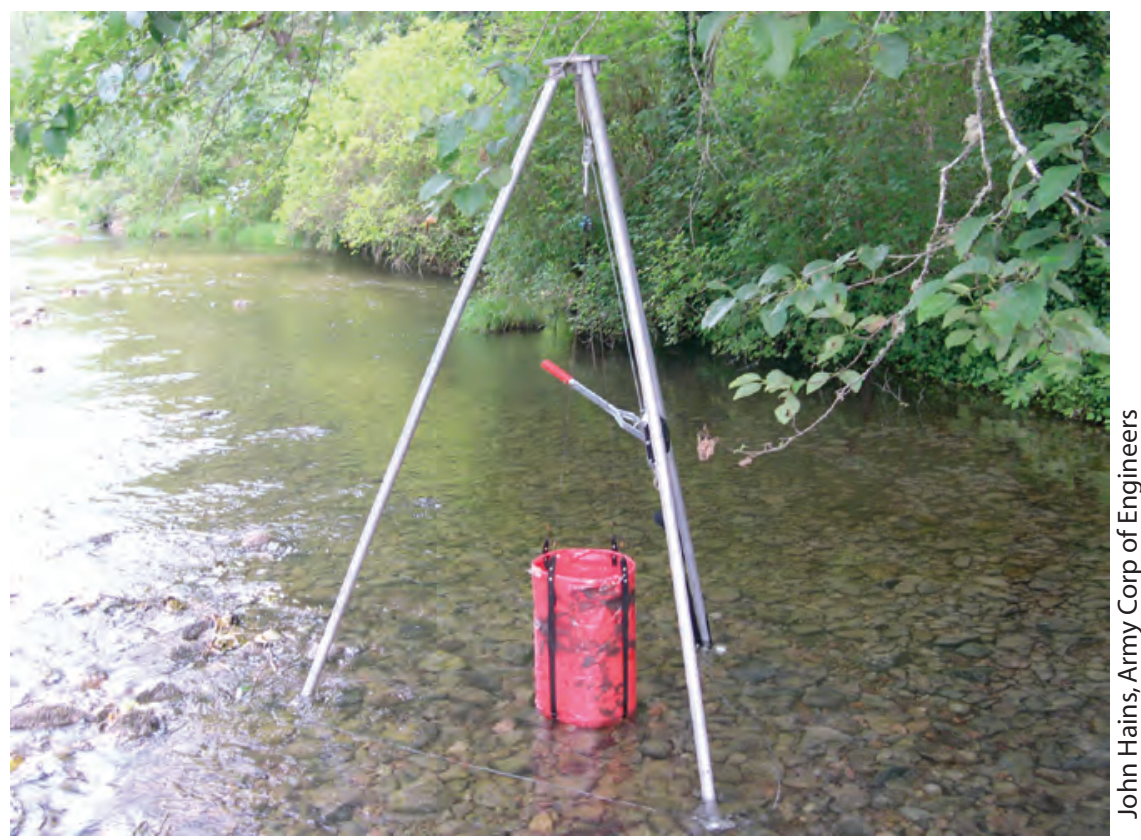

C. Tripod and winch retrieval system with a completely extracted infiltration bag

Figure 5. Infiltration bag retrieval process for measurement of deposition of fine sediment and DDT plus metabolites in the McKenzie River, Oregon, August 2004. 


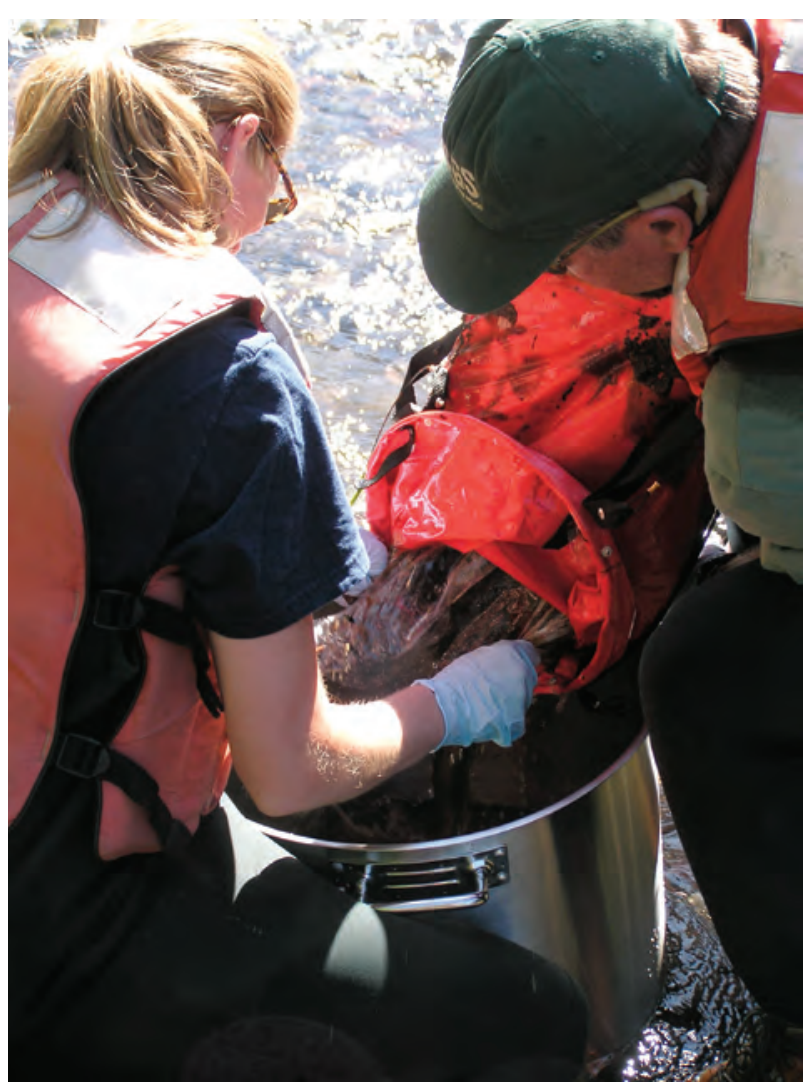

D. Pouring contents of the retrieved bag into a stainless steel bucket for subsampling

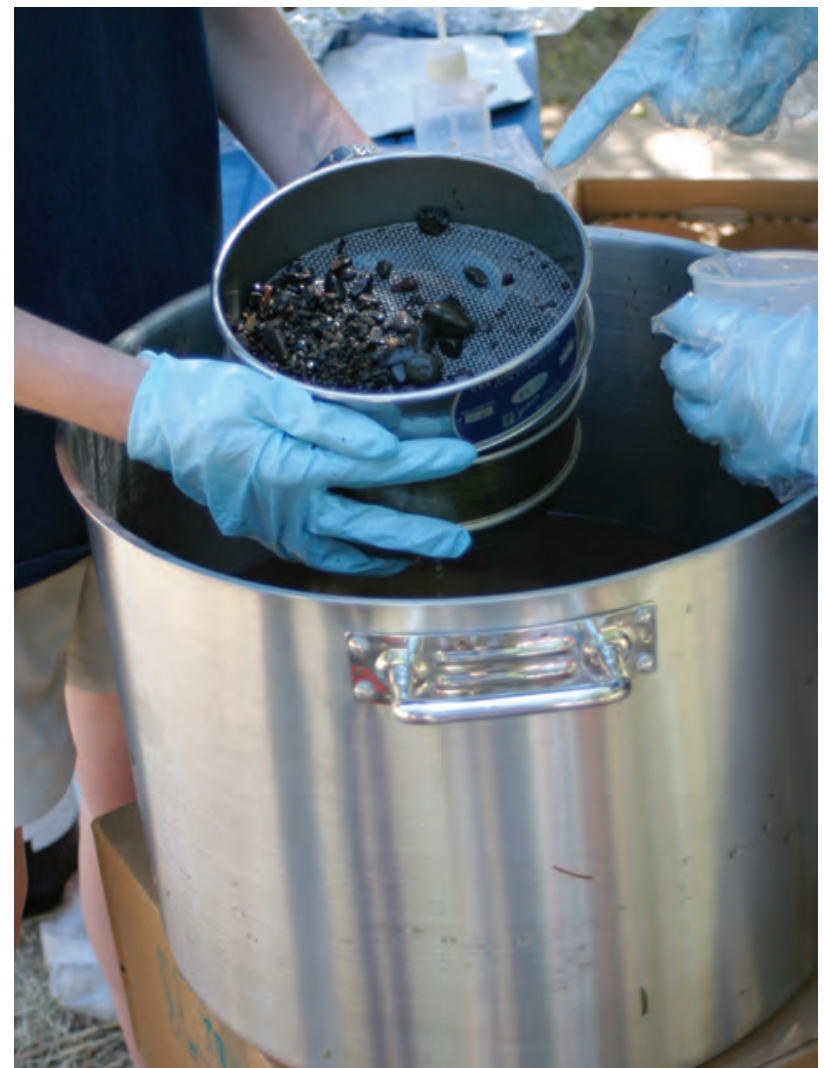

F. Sieving the remaining gravel to remove sand and larger sediments for size analysis

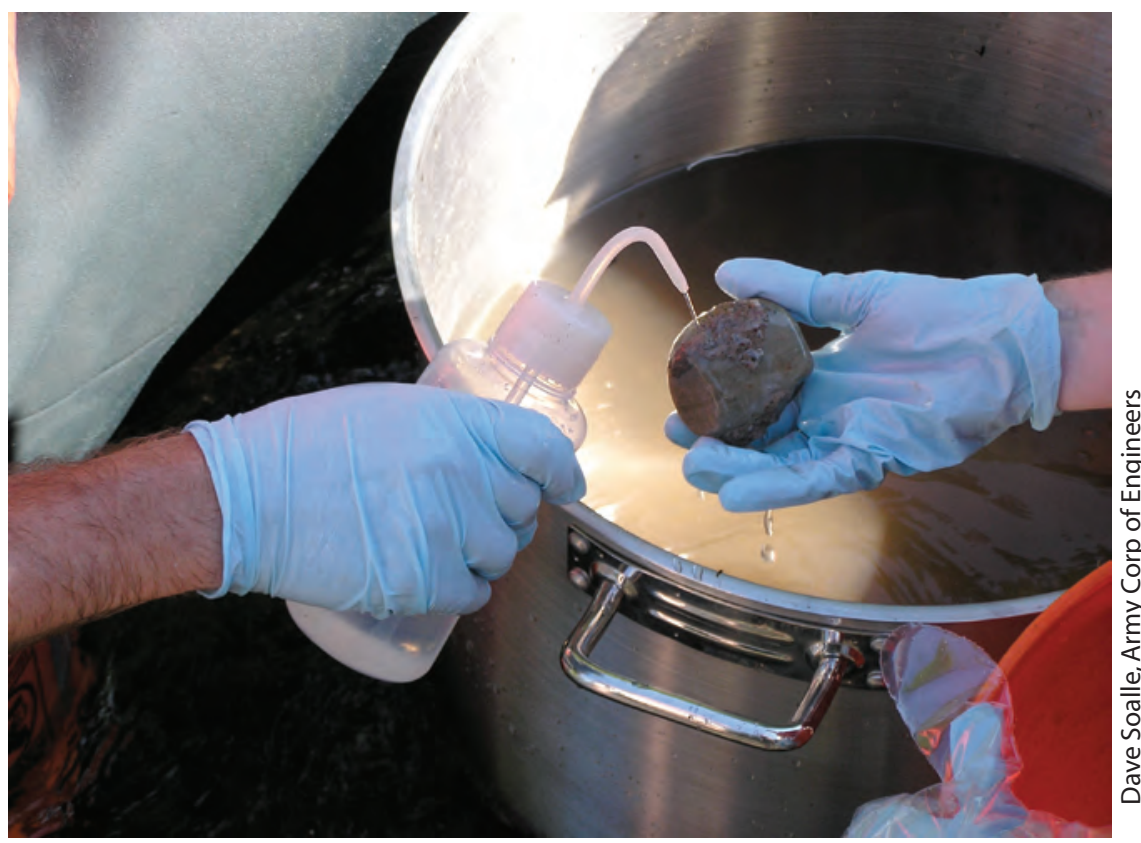

$\boldsymbol{E}$. Washing individual rocks to remove fine sediment into the bucket

Figure 5.-Continued. 


\section{Fine Sediment Content}

The mass of fine sediment $(\mathrm{Fb})$ and percentage of fine sediment $\left(\mathrm{F}_{\sigma_{6}}\right)$ with diameter $<0.063 \mathrm{~mm}$ that accumulated in infiltration bags was calculated as

$$
F_{\%}=\frac{F_{i}}{F_{i}+S_{t}} \times 100
$$

where:

$F_{\%}$ is the percentage of fine material in the infiltration bag,

$F_{i}$ is the mass of fine material in the infiltration bag, in grams, and

$S_{t}$ is the total mass of sand size and larger sediment (gravel, cobbles, and other rocks) in the infiltration bag, in grams.

In turn,

$$
F_{i}=\frac{F_{t}-F_{w}}{1,000},
$$

where:

$F_{t}$ is the total mass of fine material in the infiltration bag, in milligrams,

$F_{w}$ is the mass of fine material in the overlying surface water, in milligrams, and

$$
F_{t}=\left(S_{\%} \times C_{i} \times V_{s}\right)+\left(S_{t} \times F_{r}\right)
$$

where:

$S_{\%}$ is the laboratory value of the fraction of fine material in the pore water (from the churn splitter),

$C_{i}$ is the laboratory value of the concentration of material in the pore water (from the stainlesssteel receptacle or churn splitter) after sieving, in milligrams per liter,

$F_{r}$ is the fraction of fine material remaining with the larger sediments after sieving,

$S_{t}$ was defined previously, and

$V_{s}$ is the volume of the water and fine-sediment mixture in the stainless-steel receptacle after removal of the sand size and larger materials, in liters, and is determined as:

$$
V_{s}=0.001 \times p \times r_{s}^{2} \times z_{s},
$$

where:

$r_{s}$ is the inside radius of the stainless-steel receptacle, in centimeters, and

$z_{S}$ is the depth of water in the receptacle after removal of the sand-size and larger materials, in centimeters.

Furthermore:

$$
F_{w}=S_{\% w} \times C_{w} \times V_{w},
$$

where:

${ }_{w}$ this subscript denotes the streamwater overlying the infiltration bag and entrained in the bag upon retrieval for the laboratory value of the sediment concentration parameter $S_{\%}$ as defined previously,

$C_{w}$ is the laboratory value of the suspended sediment concentration in the overlying water, in milligrams per liter, and

$V_{w}$ is the volume of streamwater overlying the bed surface and entrained in the bag, in liters.

Vw is determined as

$$
V_{w}=0.001 \times p \times r_{b}^{2} \times z_{w}
$$

where:

$r_{b}$ is the radius of the infiltration bag $(30 \mathrm{~cm})$ and $z_{w}$ is the depth of water overlying the streambed upon retrieval (average of 5 measurements around the perimeter and center of the bag), in centimeters. 


\section{Sediment Chemistry}

Calculations for $\Sigma \mathrm{DDx}$ in the infiltration bags were performed as follows:

$$
\mathrm{S}_{\mathrm{DDx}}=\mathrm{S}_{\mathrm{DDT}}+\mathrm{S}_{\mathrm{DDD}}+\mathrm{S}_{\mathrm{DDE}},
$$

where:

SDDx is the total mass of DDT and metabolites associated with fine sediment in the infiltration bag, in micrograms,

SDDT is mass of DDT in the infiltration bag, in micrograms,

SDDD is the mass of the metabolite DDD in the infiltration bag, in micrograms, and

SDDE is the mass of the metabolite DDE in the infiltration bag, in micrograms.

The masses of DDT and its metabolites are determined from the reported aquatic concentrations for each species, as:

$$
\mathrm{S}_{\mathrm{DDT}}=0.001 \times\left(\left(F_{i} \times[\mathrm{DDT}]_{i}\right)+\left(F_{w} \times[\mathrm{DDT}]_{w}\right)\right) \text {, }
$$

where:

$[D D T]_{\mathrm{i}}$ and $[\mathrm{DDT}]_{\mathrm{w}}$ are the concentrations of the DDT species from the centrifuged sample of sediment, as submitted to the laboratory in 1-L bottles from the churn splitter, in micrograms per kilogram and in overlying water upon retrieval, respectively, and similar calculations are made for each of the other DDT species (DDD and DDE). $F_{i}$ and $F_{w}$ are as previously defined. In all cases, the concentrations of DDT or metabolites in the overlying water were nondetectable, and the $\mathrm{F}_{\mathrm{w}} *[\mathrm{DDT}]_{\mathrm{w}}$ term therefore became negligible.

The overall Method Detection Limit (MDL) for $\Sigma D D x$ is determined by the sum of the laboratory-determined MDLs for individual DDx species.

\section{Transport and Deposition of Sediment and DDT}

Daily mean discharge and turbidity during water years 2002-04 are indicated for all sites in figure 6. With the exception of the site downstream of Cougar Reservoir (CGRO), there typically were only a few periods at any site that resulted in elevated turbidities ( $>10 \mathrm{FNU}$, for example) during the study period, from January 2003 through September 2004. Maximum daily mean discharge in the South Fork above Cougar Reservoir (SFCO) was about 4,100 cubic feet per second $\left(\mathrm{ft}^{3} / \mathrm{s}\right)$ each year, whereas maximum discharge downstream of Cougar Reservoir (at CGRO) was constrained by the geometry of the dam's temporary bypass structure to about $3,000 \mathrm{ft}^{3} / \mathrm{s}$, and generally was less than $2,000 \mathrm{ft}^{3} / \mathrm{s}$. In the mainstem above the South Fork (at MRBO), maximum daily mean discharges were about $8,000 \mathrm{ft}^{3} / \mathrm{s}$, and at VIDA, the most downstream site studied, daily mean discharges were about $10,000-14,000 \mathrm{ft}^{3} / \mathrm{s}$.

Turbidity levels in the basin are characterized by generally low values ( $<1-2$ FNU) during most periods, punctuated by short spikes of elevated values during storms or other (commonly storm-related) events. Turbidities were highest downstream of Cougar Reservoir during several events; however, background turbidity in Blue River downstream of Blue River Lake during the winter drawdown period typically was elevated over that in the summer or at other sites. Turbidity at VIDA was intermediate to values measured at the regulated upstream stations (CGRO and BLUE) and to those at unregulated upstream stations (MRBO and SFCO), indicating a direct effect on the mainstem from Cougar and Blue River Reservoirs. The turbidity signal at VIDA tended to respond rapidly to inputs from the regulated tributaries, and VIDA frequently had substantially higher turbidities than those measured upstream at MRBO. 


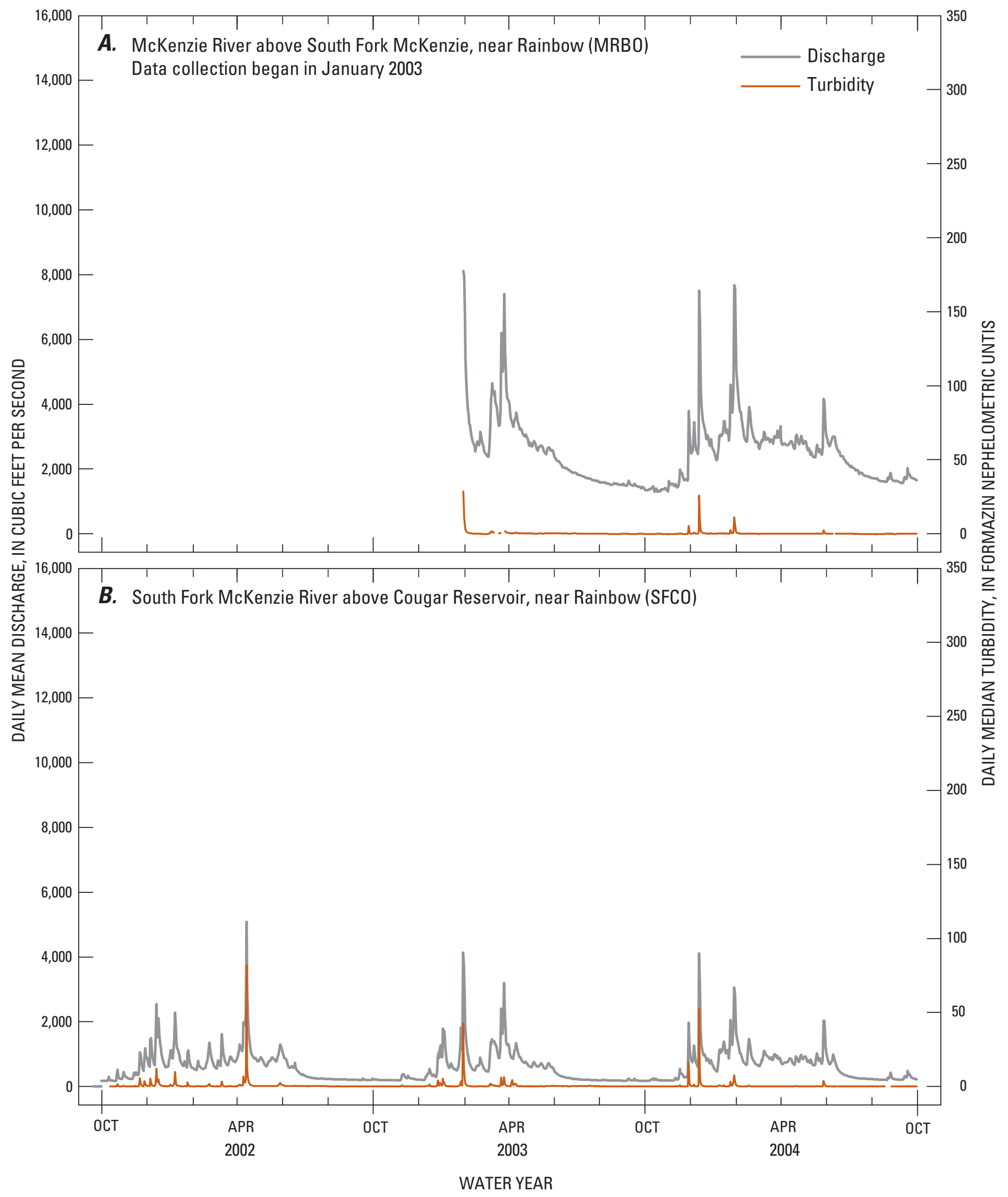

Figure 6. Discharge and turbidity at sampling sites in the McKenzie River basin, Oregon, water years 2002-04. 


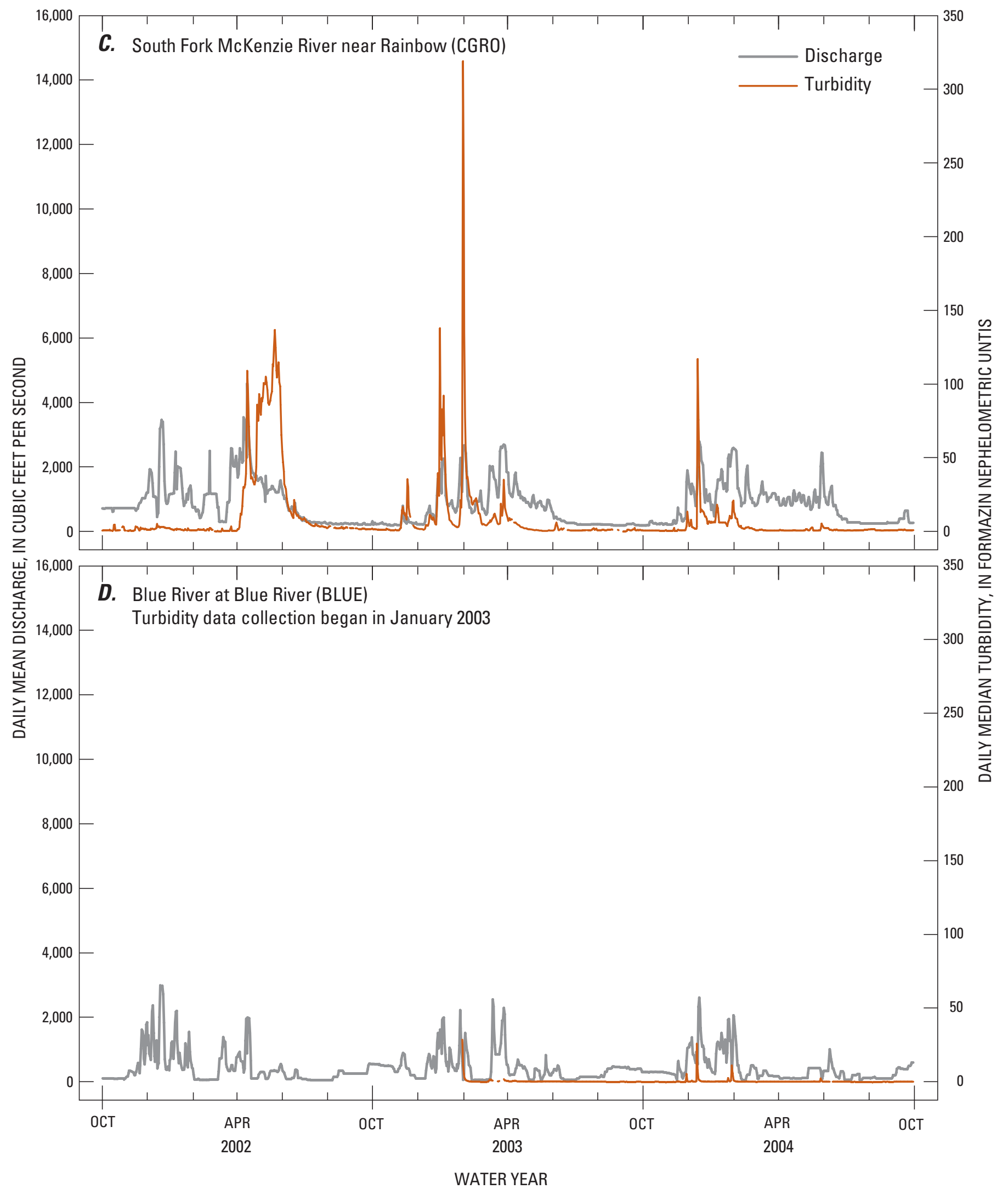

Figure 6.-Continued 


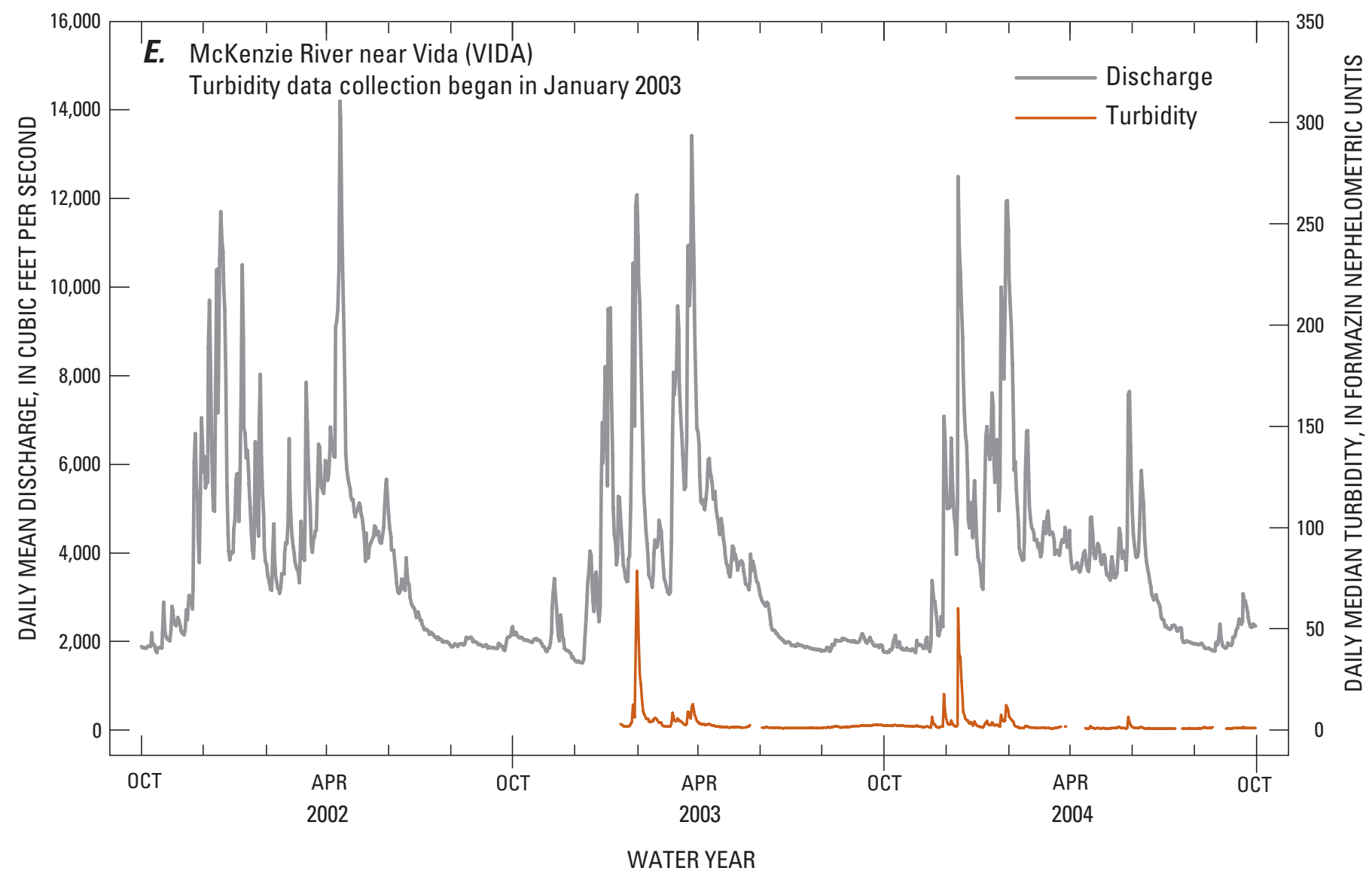

Figure 6.-Continued

\section{Suspended-Sediment Concentration}

Suspended-sediment concentration data from storm samplings are presented in table 2, along with the turbidity values obtained from the continuous monitors corresponding to the time of sampling. Although the largest storms during the study period generally were sampled, there were not as many large storms with elevated turbidity as had been anticipated. Therefore, the number of SSC samples obtained from each station was variable and generally less than originally intended. Monitored turbidity values that were less than 1 and their corresponding SSC data were not included in the regression equations because of the high variability of turbidity in the range of 0-1 FNU. Only the station downstream of Cougar Reservoir on the South Fork McKenzie (CGRO) had more than 20 samples that could be used for a regression.

Suspended-sediment concentrations measured at the different stations were highly variable and depended on the flow and weather conditions at the time of sampling. The highest sampled SSC from CGRO $(266 \mathrm{mg} / \mathrm{L})$, during the storm of January 30, 2003, occurred following the collapse of a diversion tunnel and supporting fill material within the Cougar Dam construction zone, and may not have represented typical sediments released from the reservoir during high- turbidity events. The fraction of suspended sediment with diameter less than $0.063 \mathrm{~mm}$ was 99 percent, which is higher than for most other samples from that station, perhaps reflecting the character of the fill material used to construct the coffer dam (J. Britton, U.S. Army Corps of Engineers, written commun., 2006). The SSC values at SFCO were highest (351 mg/L) during the event on December 13, 2003, when movement of the streambed was audible and discharge exceeded 5,300 $\mathrm{ft}^{3} / \mathrm{s}$. The fine fraction $(<0.063 \mathrm{~mm})$ during this sampling was only $46-48$ percent, indicating that the energy of the stream was high and that a mix of fine- and coarse-grained material was being transported.

At least one other sample from each station had fine fractions that were relatively low (less than 80 percent), even with flows or SSCs that also were somewhat low. These data indicate that concentrations of larger particles were higher than fine particles, which typically is not the case during low flows. It is unknown what may have contributed to these anomalous size fractions; possibilities include sampling or laboratory errors, which would be magnified at low concentrations. These data were not removed from the regressions because information to confirm any errors was not available and because their effect on the regressions generally was small. 
Table 2. Suspended-sediment concentrations and associated turbidity during storm sampling in the McKenzie River basin, Oregon, 2003-04.

[Samples excluded from regressions between suspended-sediment concentration and turbidity were those where turbidity was less than 0.9 FNU or was not available. No regression was performed for the McKenzie River at Hayden Bridge because not enough samples were collected. Abbreviations: $\mathrm{ft}^{3} / \mathrm{s}$, cubic foot per second; FNU, formazin nephelometric units; SSC, suspended-sediment concentration: mg/L, milligram per liter; mm, millimeter; N/A, not available; <. less than; *, sample was used in regression]

\begin{tabular}{|c|c|c|c|c|c|c|}
\hline Date & Time & $\begin{array}{c}\text { Discharge } \\
\left(\mathrm{ft}^{3} / \mathrm{s}\right)\end{array}$ & $\begin{array}{c}\text { Turbidity } \\
\text { (FNU) }\end{array}$ & $\begin{array}{c}\text { SSC } \\
(\mathrm{mg} / \mathrm{L})\end{array}$ & $\begin{array}{c}\text { Percent } \\
<0.063 \mathrm{~mm}\end{array}$ & $\begin{array}{l}\text { Samples used } \\
\text { in regression }\end{array}$ \\
\hline \multicolumn{7}{|c|}{ 14159110 —McKenzie River above South Fork McKenzie, near Rainbow (MRB0) } \\
\hline 01-14-03 & $11: 50$ & N/A & N/A & 2 & 25 & \\
\hline $01-27-03$ & $10: 17$ & N/A & N/A & 8 & 62 & \\
\hline $01-29-03$ & $16: 27$ & 3554 & 0.9 & 1 & 61 & $*$ \\
\hline 03-08-03 & $11: 10$ & 4,314 & 1.6 & 4 & N/A & * \\
\hline $04-14-03$ & $13: 05$ & 3,396 & .3 & 1 & 50 & \\
\hline $12-13-03$ & $13: 34$ & 8,505 & 35.1 & 106 & 47 & $*$ \\
\hline $12-14-03$ & $11: 20$ & 6,174 & 8.2 & 17 & 63 & $*$ \\
\hline $01-22-04$ & $09: 30$ & 2,852 & $<.1$ & 2 & 73 & \\
\hline
\end{tabular}

\begin{tabular}{|c|c|c|c|c|c|c|}
\hline \multicolumn{7}{|c|}{ 14159200 - South Fork McKenzie River above Cougar Reservoir, near Rainbow (SFCO) } \\
\hline 01-03-03 & 12:02 & 1,860 & 6.9 & 6 & 74 & \multirow[t]{2}{*}{ * } \\
\hline 01-13-03 & $17: 20$ & 634 & .1 & 2 & 44 & \\
\hline 01-26-03 & $15: 12$ & 1,121 & 1.1 & 4 & 59 & * \\
\hline 01-31-03 & $10: 15$ & 4,620 & 26.3 & 38 & 49 & * \\
\hline 03-07-03 & $16: 30$ & 1,151 & 2.4 & 6 & 43 & * \\
\hline $03-13-03$ & 17:04 & 1,362 & .5 & 14 & 68 & \\
\hline 04-14-03 & $17: 24$ & 1,008 & .1 & 2 & 65 & \\
\hline $12-13-03$ & $15: 30$ & 5,394 & 91.4 & 310 & 46 & $*$ \\
\hline $12-13-03$ & $16: 40$ & 5,713 & 118.7 & 351 & 48 & $*$ \\
\hline $01-28-04$ & $15: 45$ & 1,804 & 4.8 & 6 & 78 & $*$ \\
\hline 02-10-04 & $13: 43$ & 766 & $<.1$ & 21 & 84 & \\
\hline \multicolumn{7}{|c|}{ Total number of samples used in Regression: 9} \\
\hline
\end{tabular}

\begin{tabular}{|c|c|c|c|c|c|c|}
\hline \multicolumn{7}{|c|}{ 14159500 — South Fork McKenzie River near Rainbow (CGRO) } \\
\hline 01-03-03 & $12: 35$ & 2,210 & 91.4 & 65 & 99 & * \\
\hline 01-14-03 & $14: 15$ & 900 & 7.2 & 6 & 88 & * \\
\hline $01-27-03$ & $08: 15$ & 1,716 & 8.1 & 8 & 85 & * \\
\hline 01-29-03 & $17: 40$ & 1,657 & 14.4 & 15 & 89 & $*$ \\
\hline $01-30-03$ & $14: 00$ & 623 & 334 & 266 & 99 & * \\
\hline $01-31-03$ & $11: 50$ & 2,596 & 320.3 & 211 & 98 & * \\
\hline 02-01-03 & $09: 35$ & 2,655 & 232 & 151 & 96 & * \\
\hline 02-03-03 & $16: 50$ & 2,633 & 74.5 & 50 & 96 & * \\
\hline 02-06-03 & $12: 24$ & 1,046 & 37 & 27 & 96 & * \\
\hline $02-12-03$ & $09: 23$ & 568 & 20.1 & 13 & 95 & * \\
\hline 03-08-03 & $13: 35$ & 2,080 & 5.8 & 4 & 97 & * \\
\hline 03-13-03 & $13: 45$ & 1,728 & 9.6 & 9 & 67 & * \\
\hline $04-15-03$ & 18:00 & 1,170 & 4.4 & 6 & 83 & * \\
\hline $11-29-03$ & 18:02 & 1,891 & 11.9 & 10 & 90 & * \\
\hline $11-30-03$ & 00:02 & 1,891 & 15.5 & 14 & 93 & * \\
\hline $11-30-03$ & 06:02 & 1,891 & 14.5 & 12 & 93 & * \\
\hline $11-30-03$ & $12: 02$ & 1,889 & 13.4 & 11 & 92 & * \\
\hline $11-30-03$ & $18: 02$ & 1,889 & 11.9 & 9 & 90 & * \\
\hline
\end{tabular}


Table 2. Suspended sediment concentrations and associated turbidity during storm sampling in the McKenzie River Basin, Oregon, 2003-04.-Continued

[Samples excluded from regressions between suspended-sediment concentration and turbidity were those where turbidity was less than 0.9 FNU or was not available. No regression was performed for the McKenzie River at Hayden Bridge because not enough samples were collected. Abbreviations: $\mathrm{ft}^{3} / \mathrm{s}$, cubic foot per second; FNU, formazin nephelometric units; SSC, suspended-sediment concentration; mg/L, milligram per liter; mm, millimeter; N/A, not available; <, less than; *, sample was used in regression]

\begin{tabular}{|c|c|c|c|c|c|c|}
\hline Date & Time & $\begin{array}{c}\text { Discharge } \\
\left(\mathrm{ft}^{3} / \mathrm{s}\right)\end{array}$ & $\begin{array}{l}\text { Turbidity } \\
\text { (FNU) }\end{array}$ & $\begin{array}{c}\text { SSC } \\
\text { (mg/L) }\end{array}$ & $\begin{array}{c}\text { Percent } \\
<0.063 \mathrm{~mm}\end{array}$ & $\begin{array}{l}\text { Samples used } \\
\text { in regression }\end{array}$ \\
\hline \multicolumn{7}{|c|}{ 14159500 — South Fork McKenzie River near Rainbow (CGR0)—Continued } \\
\hline $12-01-03$ & 00:02 & 1,876 & 10.1 & 8 & 72 & $*$ \\
\hline $12-14-03$ & $14: 20$ & 2,830 & 112.7 & 88 & 97 & * \\
\hline $12-15-03$ & $10: 30$ & 2,813 & 77.6 & 55 & 97 & * \\
\hline $12-15-03$ & $12: 30$ & 2,813 & 74.2 & 48 & 97 & * \\
\hline $12-23-03$ & $12: 00$ & 1,064 & 12 & 12 & 87 & * \\
\hline 01-21-04 & $15: 55$ & 1,477 & 5.2 & 4 & 88 & * \\
\hline 01-30-04 & $08: 30$ & 2,554 & 20.2 & 19 & 93 & * \\
\hline $05-27-04$ & $09: 35$ & 969 & .5 & 2 & 77 & \\
\hline $05-27-04$ & $09: 36$ & 969 & .5 & 3 & 56 & \\
\hline \multicolumn{7}{|c|}{ Total number of samples used in Regression: 25} \\
\hline \multicolumn{7}{|c|}{ 14162200—Blue River at Blue River (BLUE) } \\
\hline 01-03-03 & $12: 55$ & 1,923 & N/A & 17 & 99 & \\
\hline 01-14-03 & $11: 52$ & 1,040 & 5.8 & 4 & 96 & * \\
\hline $01-27-03$ & $12: 27$ & 2,761 & 15.7 & 14 & 91 & * \\
\hline 01-30-03 & $10: 18$ & 616 & 17.2 & 10 & 97 & * \\
\hline $01-31-03$ & $16: 55$ & 69 & 9.1 & 14 & 82 & * \\
\hline $03-08-03$ & $15: 10$ & 73 & 3.3 & 6 & 61 & * \\
\hline $04-15-03$ & $14: 10$ & 694 & 2.6 & 2 & 85 & * \\
\hline $12-05-03$ & $09: 50$ & 1,131 & 12.6 & 10 & 91 & * \\
\hline $12-15-03$ & $13: 40$ & 2,527 & 44.7 & 30 & 98 & * \\
\hline $01-22-04$ & $11: 40$ & 510 & N/A & 8 & 77 & \\
\hline $05-27-04$ & $15: 20$ & 415 & 2.5 & 1 & 81 & * \\
\hline \multicolumn{7}{|c|}{ Total number of samples used in Regression: 9} \\
\hline \multicolumn{7}{|c|}{ 14162500—McKenzie River near Vida (VIDA) } \\
\hline 01-03-03 & 10:10 & 10,074 & N/A & 20 & 87 & \\
\hline $01-14-03$ & $09: 25$ & 5,340 & 3.7 & 4 & 74 & * \\
\hline $01-27-03$ & $14: 25$ & 11,062 & 14.1 & 21 & 54 & $*$ \\
\hline $01-31-03$ & $12: 00$ & 11,947 & 83.2 & 72 & 89 & $*$ \\
\hline 02-01-03 & $11: 00$ & 11,343 & 60.1 & 51 & 84 & * \\
\hline $02-03-03$ & $12: 50$ & 9,544 & 26.2 & 18 & 91 & * \\
\hline $02-06-03$ & $13: 44$ & 5,989 & 8.7 & 7 & 90 & * \\
\hline $04-17-03$ & $14: 05$ & 5,247 & 2.2 & 2 & 84 & * \\
\hline $12-13-03$ & $12: 29$ & 13,364 & 67.8 & 41 & 74 & * \\
\hline $12-14-03$ & $08: 50$ & 10,626 & 26.5 & 25 & 83 & * \\
\hline $01-22-04$ & $14: 35$ & 4,771 & 1.9 & 3 & 65 & * \\
\hline 01-29-04 & $15: 30$ & 12,270 & 13.9 & 33 & 54 & * \\
\hline \multicolumn{7}{|c|}{ Total number of samples used in Regression: 11} \\
\hline \multicolumn{7}{|c|}{ 440418122574500—McKenzie River at Hayden Bridge, near Springfield, OR } \\
\hline 01-14-03 & $16: 35$ & N/A & N/A & 8 & 75 & \\
\hline $01-27-03$ & $16: 27$ & N/A & 19.1 & 56 & 56 & \\
\hline $02-01-03$ & $14: 30$ & N/A & N/A & 69 & 70 & \\
\hline $12-15-03$ & $16: 20$ & N/A & 2.24 & 47 & 71 & \\
\hline $01-22-04$ & $16: 45$ & N/A & N/A & 5 & 65 & \\
\hline
\end{tabular}


In general, the percentage of suspended sediment $<0.063$ $\mathrm{mm}$, shown in figure 7 as the medians of all samples from each station, indicates differences in the character of the sediment being transported at the individual stations. The unregulated stations (SFCO and MRBO) tended to have a lower percentage of sediment as fine material, around 50-60 percent, and higher variability (table 2), whereas the regulated stations (BLUE and CGRO) typically had more than 90 percent of the suspended sediment as fine material, with less variation. The percentage of fine material was intermediate at VIDA, where a large component of the discharge originates from unregulated upstream reaches (represented by MRBO), but where suspended-sediment concentrations are apparently disproportionately influenced by releases from Blue River and Cougar Reservoirs. The differences in standard deviation of fine fraction among the sites indicate a dependence of the sediment character at a particular site on the stream's energy, a primary difference between regulated and unregulated sites (Collier and others, 1996). Standard deviations in fine fractions were 11 percent at both regulated sites, 17 percent at both unregulated sites, and intermediate (13 percent) at VIDA. However, this finding should be treated as hypothesis rather than fact owing to different numbers of samples among sites and relatively few samples at some sites.

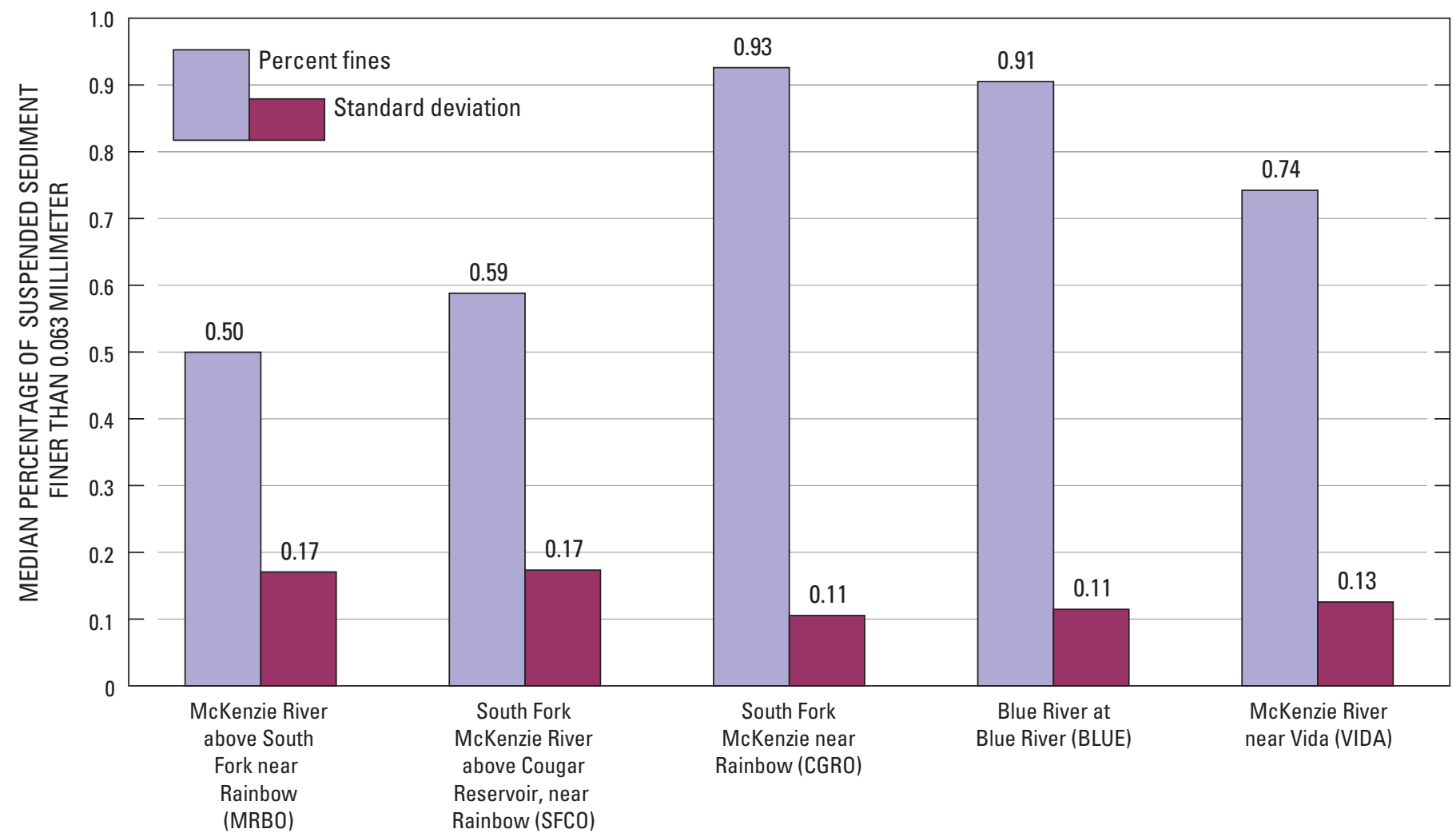

STATION

Figure 7. Median percentage of fine material (less than 0.063 millimeter) and standard deviation in percentage of fine material of suspended sediment at gaging stations in the McKenzie River basin, Oregon, 2003-04. 


\section{Regressions of Turbidity and Suspended- Sediment Concentrations}

The regression equations and associated statistics for all stations are shown in table 3. With the exception of the regression at Blue River, SSC-turbidity correlations from all sites had $r^{2}$ values greater than 90 percent, meaning that turbidity explained more than 90 percent of the variability in SSC at those sites.

Although sampling was targeted at events with high SSC and high turbidities in order to develop regressions that encompass the range of measured turbidity values at each site, maximum sampled turbidities were less than the maximums recorded by the continuous monitors at all stations (table 3). The estimation of SSC from regressions on turbidity, at turbidities beyond the maximum sampled value, is assumed by linear extension of the model, but remains unverified. Thus, during brief periods, estimated records of suspended-sediment concentration and load are tenuous and should be used qualitatively. This is especially true because a high percentage of the suspended-sediment load tends to be transported during the largest events, which are not entirely represented by the turbidity-SSC regressions generated. However, most of the instances of recorded turbidities greater than those sampled were anomalous events and are summarized as follows:

- At CGRO, the maximum turbidity sampled was 334 FNU. During 2002, the tunnel tap resulted in a short period with instantaneous values that were off the scale of the turbidimeter at that station $(>1,360 \mathrm{FNU})$ for less than 1 hour. During the collapse of the Rush Creek diversion tunnel in January 2003, turbidities steadily decreased from 1,020 to 350 FNU in about 8 hours.

Table 3. Regression equations and correlation coefficients for relations between turbidity and suspended-sediment concentrations, McKenzie River basin, Oregon.

[Equations are in the form $\mathrm{y}=\mathrm{bx}{ }^{\mathrm{a} *} \mathrm{cf}$, where $\mathrm{y}$ is suspended-sediment concentration (SSC), in milligram per liter, $\mathrm{x}$ is the reported, instantaneous turbidity, in formazin nephelometric units (FNU), $a$ and $b$ are regression coefficients, and of is a bias correction factor. Turbidities listed as $>1,360$ FNU were higher than the upper limit of the instrument—loads may be computed with the value 1,360 FNU and are considered underestimates of the actual load. Maximum turbidity sampled is the highest recorded turbidity value with a corresponding SSC sample, whereas Maximum Turbidity Recorded is the highest turbidity value recorded at the site during the study period, showing the degree to which regressions of SSC from turbidity were extended beyond the nominal bounds of the regression. The range of SSC values shown are those that were sampled and used in the regressions. SSC values below the indicated ranges were not used. Model standard prediction error (MSPE), calculated as $+\mathrm{MSPE}=\left[10^{\wedge}(+\mathrm{MSE})-1\right]^{*} 100$, and $-\mathrm{MSPE}=\left[1-10^{\wedge}(-\mathrm{MSE})\right]^{*} 100$. Abbreviations: $\mathrm{mg} / \mathrm{L}$, milligram per liter; FNU, Formazin Nephelometric Units; >, greater than; \pm , plus or minus]

\begin{tabular}{|c|c|c|c|c|c|c|c|c|c|}
\hline Station name & $\begin{array}{l}\text { Equation } \\
{\left[y=b(x)^{a}\right]}\end{array}$ & $\begin{array}{l}\text { Correction } \\
\text { factor } \\
\text { (cf) }\end{array}$ & $\begin{array}{c}\text { Number } \\
\text { of } \\
\text { samples }\end{array}$ & $\begin{array}{c}\text { Correlation } \\
\text { coefficient } \\
r^{2}\end{array}$ & $\begin{array}{l}\text { Mean } \\
\text { square } \\
\text { error } \\
\text { (MSE) }\end{array}$ & $\begin{array}{l}\text { Model } \\
\text { standard } \\
\text { prediction } \\
\text { error }( \pm)\end{array}$ & $\begin{array}{l}\text { Range of } \\
\text { turbidity } \\
\text { sampled } \\
\text { (FNU) }\end{array}$ & $\begin{array}{l}\text { Maximum } \\
\text { turbidity } \\
\text { recorded } \\
\text { (FNU) }\end{array}$ & $\begin{array}{c}\text { Range of } \\
\text { SSC } \\
\text { (mg/L) }\end{array}$ \\
\hline $\begin{array}{l}\text { South Fork McKenzie River } \\
\text { above Cougar Lake, near } \\
\text { Rainbow (SFCO) }\end{array}$ & $2.233^{*} \operatorname{Turb}^{(1.012)}$ & 1.123 & 9 & .92 & .070 & $17.5 / 14.9$ & $1.1-119$ & 323 & $4-17$ \\
\hline $\begin{array}{c}\text { South Fork McKenzie River } \\
\text { near Rainbow (CGRO) }\end{array}$ & $1.079^{*} \operatorname{Turb}^{(0.916)}$ & 1.013 & 25 & .98 & .005 & $1.16 / 1.14$ & $5.2-334$ & $>1,360$ & $4-351$ \\
\hline $\begin{array}{l}\text { Blue River at Blue River } \\
\text { (BLUE) }\end{array}$ & $1.027 * \operatorname{Turb}^{(0.946)}$ & 1.107 & 9 & .81 & .045 & $10.9 / 9.8$ & $2.5-45$ & 103 & $1-30$ \\
\hline $\begin{array}{l}\text { McKenzie River near Vida } \\
\text { (VIDA) }\end{array}$ & $1.520 * \operatorname{Turb}^{(0.875)}$ & 1.069 & 11 & .91 & .027 & $6.4 / 6.0$ & $19-83$ & 143 & $2-72$ \\
\hline
\end{tabular}


- For SFCO, there was one instantaneous turbidity value in each of water years 2003 (182 FNU) and 2004 (128 FNU) when turbidity values exceeded the maximum sampled for the regression (119 FNU). During 2003, this occurred on April 5 and was a result of an earthflow upstream in the Hardy Creek drainage (D. Kretzing, U.S. Forest Service, written commun., 2003), where material occasionally sloughed into the creek, causing a noticeable plume. During water year 2004, the peak value occurred during the storm of December 13, 2003, about 1 hour after the sampled turbidity of 118 FNU was collected. An event on April 14, 2002, resulted in an 8-hour period when turbidities were greater than 119 FNU at SFCO, reaching a maximum of $323 \mathrm{FNU}$.

- Likewise, at VIDA, there were 6.5 hours during the storm of December 13, 2003, when the recorded turbidity was over the maximum value sampled ( $83 \mathrm{FNU}$ ), reaching the 2-year maximum of $143 \mathrm{FNU}$ before the rain turned to snow and dampened the river's response to the storm. During a storm on November 29, 2003, recorded turbidity reached $120 \mathrm{FNU}$ for about 30 minutes.

- The maximum turbidity sampled at MRBO (52 FNU) was equivalent to the maximum value recorded during the storm of January 30, 2003, (53 FNU), and was exceeded for 6 hours during the storm of December 13, 2003 , with a maximum turbidity of 80 FNU.

The only site with substantial time periods (days, rather than hours) where recorded turbidities exceeded the maximum sampled was Blue River below Blue River Reservoir. At that station, the maximum value sampled was 45 FNU, but there were three periods during autumn 2003 when recorded turbidities exceeded this sampled value. On November 17, one recorded value was 57 FNU. During the period from November 27 at 3:30 a.m. to November 29 at 10:30 p.m., a period of about 2.75 days, recorded turbidity values ranged from 45 to $103 \mathrm{FNU}$, with a median of $56 \mathrm{NFU}$. Finally, following the storm of December 13, 2003, recorded turbidities increased sharply due to construction work to stabilize a landslide that had covered State Highway 15 along the east shore of the reservoir-mud and debris removed from the road entered the upstream arm of the reservoir around 10 a.m., and by noon the turbidity values began to increase as the plume made its way through the reservoir and out the dam. This activity resulted in turbidities greater than 45 FNU (maximum 70 and median $61 \mathrm{FNU}$ ) for slighly longer than 1 day.

Suspended-sediment and turbidity data from each site, along with corresponding linear and power-function regression lines (from table 3), are shown in figure 8. Although SSC computations for estimation of loads are performed using power functions from table 3 , linear plots are included in figure $8 \mathrm{~A}$ to demonstrate the differences in slopes among stations. These differences potentially represent differences in the character of the sediment as it affects the optical quality of the turbidity measurement from station to station. Regression slopes for the unregulated stations were higher, indicating a higher concentration of suspended sediment is being transported for a given turbidity than at the regulated stations. This finding is consistent with data in figure 7 showing that the percentage of fine material in the suspended phase was higher at the regulated sites than at the unregulated sites. It also is consistent with theoretical aspects of turbidity monitoring, wherein smaller particles tend to cause a proportionally higher scattering of light, translating to higher nephelometric turbidity, than do larger particles (Brumberger and others, 1968; Sadar, 1998; Anderson, 2004). Color also can affect turbidity readings; however, the instruments used, with a near-infrared light source, are moderately robust with regard to the influence of color on turbidity (Anderson, 2004). In this case, the slope for VIDA also is similar to those from CGRO and BLUE, indicating that the sediment characteristics at VIDA may be determined more by sediment exported from the South Fork and Blue River than from sediment transported from reaches farther upstream.

Although the potential reasons for differences in slopes among the sites are consistent with other data in this study, they must be treated as hypotheses requiring further testing because the number of samples available for the analysis was relatively small. Additional data from the unregulated stations (MRBO and SFCO) might have resulted in modified turbidity-SSC regressions that were less distinct than those from the regulated sites; alternatively, the relations observed at CGRO may have been strongly influenced by events associated with the construction project itself (for example, the collapse of the Rush Creek Diversion or erosion of upstream deltaic sediments) and may not be valid when the reservoir is operating normally following completion of the construction project and refilling of the reservoir. 

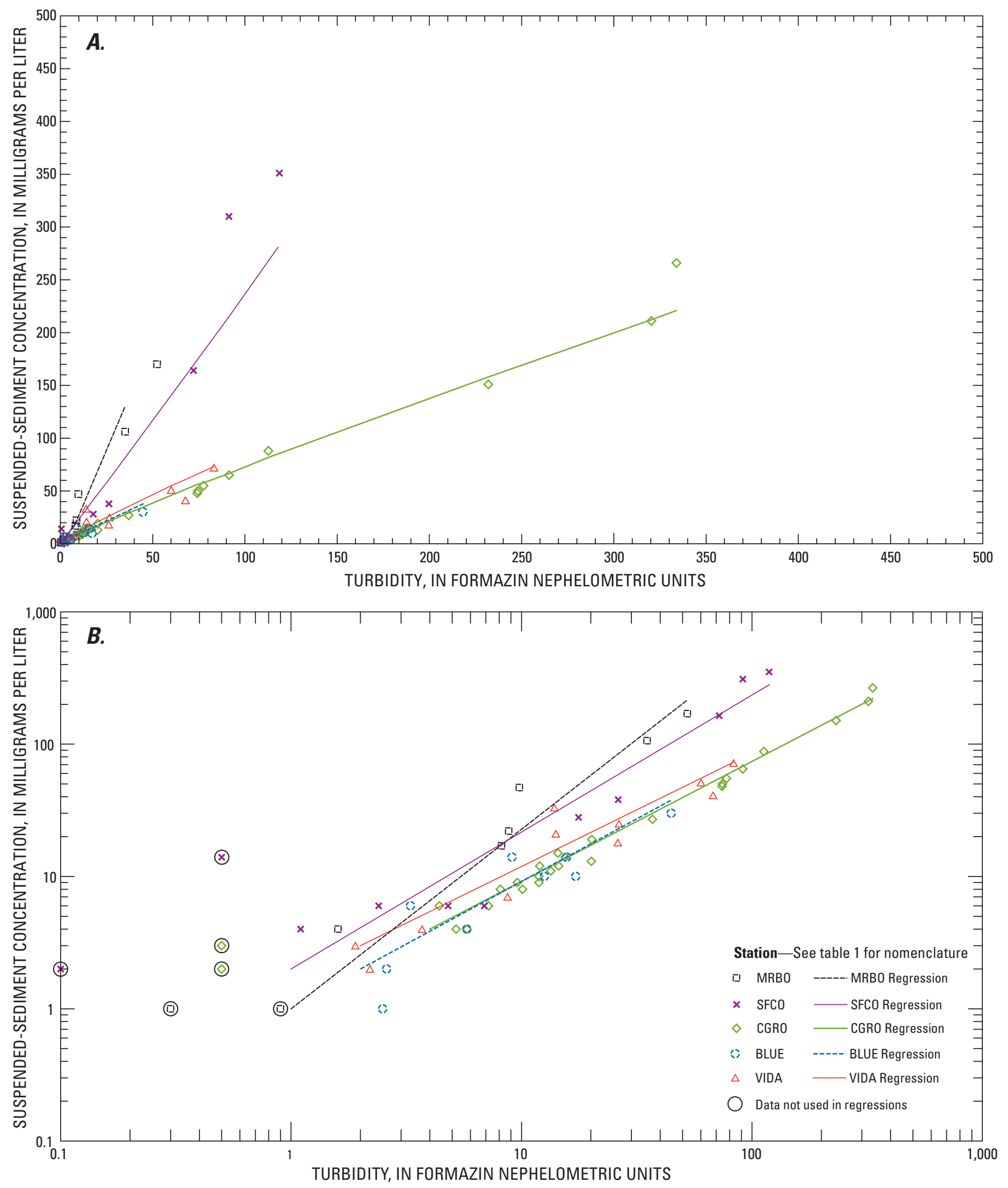

Figure 8. Regression using $(A)$ linear, and $(B)$ power-function regression lines for turbidity and concentration of suspended sediment at study sites in the McKenzie River basin, Oregon, water years 2002-04. Power functions are presented in table 3. 


\section{Sediment Loads}

By using instantaneous turbidity data from the McKenzie River Basin continuous monitors and the derived turbiditySSC regressions (table 3), instantaneous concentrations of suspended sediment were estimated on a thirty-minute basis for the periods of record at each site during water years 2002-04. From these estimated concentrations and instantaneous discharge data, SSLs were estimated on an instantaneous (every thirty minutes), daily mean, and annual basis as previously described. Annual discharge and suspended-sediment loads are presented in table 4. For MRBO, BLUE, and VIDA, where turbidity monitors were not installed until January, 2003, water year 2004 is the only water year with complete data and therefore the only year for which annual loads could be calculated. Partialyear loads were calculated for water year 2003 beginning in January 2003, when turbidimeters were installed at BLUE, MRBO, and VIDA. For comparison purposes, a partial-year record covering the same period was calculated for SFCO and CGRO.

Table 4. Estimated annual discharge, suspended-sediment load, and discharge-weighted suspended-sediment concentrations at gaging stations in the McKenzie River, Oregon, water years 2002-04, as derived from continuous measurements of discharge and turbidity, and regressions of turbidity and suspended-sediment concentration.

[Streamflow data for complete years are from the U.S. Geological Survey $(2002,2003,2004)$. Discharge-weighted suspended-sediment concentration is determined as the annual suspended-sediment load divided by the annual discharge, with conversion for measurement units. Monitors were installed during January 2003 at MRBO, BLUE, and VIDA; hence, loads and concentrations indicated are for partial records during water year 2003 at those sites. Abbreviations: mg/L, milligram per liter; -, no data]

\begin{tabular}{|c|c|c|c|c|}
\hline Station name & Water year & $\begin{array}{c}\text { Annual } \\
\text { discharge } \\
\text { (acre-feet) }\end{array}$ & $\begin{array}{c}\text { Annual } \\
\text { suspended- } \\
\text { sediment load } \\
\text { (tons) }\end{array}$ & $\begin{array}{l}\text { Annual, discharge- } \\
\text { weighted, } \\
\text { suspended- } \\
\text { sediment } \\
\text { concentration } \\
\text { (mg/L) }\end{array}$ \\
\hline \multirow{3}{*}{$\begin{array}{l}\text { McKenzie River above South Fork McKenzie, } \\
\text { near Rainbow (MRBO) }\end{array}$} & 2002 & - & - & - \\
\hline & ${ }^{1} 2003$ & ${ }^{1} 1,204,000$ & ${ }^{1} 4,800$ & ${ }^{1} 2.9$ \\
\hline & 2004 & $1,789,000$ & 5,800 & 2.4 \\
\hline \multirow{4}{*}{$\begin{array}{l}\text { South Fork McKenzie River above Cougar } \\
\text { Reservoir, near Rainbow (SFCO) }\end{array}$} & 2002 & 467,900 & 6,800 & 10.7 \\
\hline & 2003 & 493,000 & 2,900 & 4.3 \\
\hline & ${ }^{1} 2003$ & ${ }^{1} 290,000$ & ${ }^{12} 2,600$ & ${ }^{1} 6.6$ \\
\hline & 2004 & 467,200 & 3,100 & 4.9 \\
\hline \multirow{4}{*}{$\begin{array}{l}\text { South Fork McKenzie River near Rainbow } \\
\text { (CGRO) }\end{array}$} & 2002 & 703,900 & 17,000 & 17.8 \\
\hline & 2003 & 392,400 & 10,900 & 20.4 \\
\hline & ${ }^{1} 2003$ & ${ }^{1} 360,000$ & 17,400 & ${ }^{1} 15.0$ \\
\hline & 2004 & 599,300 & 4,100 & 5.0 \\
\hline \multirow[t]{4}{*}{ Blue River at Blue River (BLUE) } & 2002 & 314,300 & - & - \\
\hline & 2003 & 317,500 & - & - \\
\hline & ${ }^{1} 2003$ & ${ }^{1} 124,800$ & ${ }^{1} 1,400$ & ${ }^{1} 8.5$ \\
\hline & 2004 & 285,400 & 3,200 & 8.2 \\
\hline \multirow[t]{4}{*}{ McKenzie River near Vida (VIDA) } & 2002 & $2,917,000$ & - & - \\
\hline & 2003 & $2,577,000$ & - & - \\
\hline & ${ }^{1} 2003$ & ${ }^{1} 1,818,400$ & ${ }^{1} 20,000$ & ${ }^{1} 7.4$ \\
\hline & 2004 & $2,743,000$ & 16,900 & 4.5 \\
\hline
\end{tabular}

${ }^{1}$ Based on partial year of data from January 29-September 30. 
Estimated annual loads were variable from year to year at all stations (table 4), depending on events occurring in each year. For instance, the load at SFCO during 2002 was 6,800 tons (or about 7,500 metric tons), most of which (>65 percent) was transported during one storm on April 13-16, 2002 (see fig. 6, appendix A), during the initial drawdown period. The same storm represented the first time the newly exposed deltaic sediments in the upper reaches of the Cougar Reservoir pool had been subjected to scouring flows since the reservoir was filled in 1953, and caused a large amount of erosion and channel changes through the valley bottom within the drawn down reaches of the reservoir and tributaries. The combination of a large influx of sediment from both the upstream reaches of the South Fork, upstream of the reservoir, and from erosion within the reservoir's drawdown area, resulted in a high turbidity peak and the downstream transport of large amounts of suspended sediment. Much of the eroded sediment appears to have passed through the reservoir and into the South Fork below Cougar Dam. Of the estimated 17,000 tons that was released from Cougar Dam (measured at CGRO) during 2002 (table 4), about 14 percent (2,400 tons) was transported during the storm of April 13-16, 2002. Subsequently, high turbidity released from the dam during spring 2002 (fig. 3) resulted in a daily median load of about 240 tons of suspended sediment until mid-June. Some of this load likely was the result of persistently suspended fine particles within the reservoir pool from the storm of April 13-16, 2002, and some smaller subsequent events, and some was from the nearly continuous evolution of the stream channel resulting from everyday flows in the exposed arms of the reservoir as the channel reached a new equilibrium position.

During water year 2003, additional sediment transport from the reservoir occurred during storms near the end of December 2002 and again at the end of January 2003 (fig. 6); however, the overall annual suspended-sediment load at CGRO was reduced compared to that in water year 2002 (table 4). Although the high daily median turbidity at CGRO on January 31 was significantly affected by the collapse of the Rush Creek Diversion, the storm also caused a major reconfiguration and downcutting of the upstream river channel through the exposed deltaic sediments (fig. 9), which was therefore another important source for high turbidity on that date. During this storm, the river pulled away from the left bank of the South Fork McKenzie River within the drawndown portion of the reservoir near Terwilliger Hot Springs, effectively straightening through several large channel features and previous meanders. Similar changes happened in the side channels, particularly the East Fork of the McKenzie River, a tributary to the South Fork in the middle of Cougar Reservoir, a few miles downstream of the Terwilliger overlook, and selected other locations where sloughing or other erosion occurred during the same storm. These changes resulted in a prolonged release of high-turbidity water from the reservoir and transport downstream into the McKenzie River past the gaging station at Vida. On the basis of instantaneous sediment concentrations computed from turbidity-SSC relations, the period January 30-February 4 accounted for the downstream transport of 36 percent of the annual load at CGRO during water year 2003. Similarly, 28 percent of the annual load moved from December 27, 2002, to January 7, 2003. During both of these events, poorly mixed plumes of elevated turbidity were plainly visible in the mainstem downstream of the mouth of the South Fork McKenzie River.

The suspended-sediment load was markedly decreased during water year 2004 at CGRO compared to the preceding 2 years (fig. 10), despite the fact that annual discharge during water year 2004 increased by almost 50 percent from water year 2003 (table 4). This decrease in load was likely a result of the stabilization of the channel and banks by plant growth in the exposed arms of the reservoir, and the establishment of an equilibrium channel configuration. Scouring flows were experienced during water year 2004, including a bed moving event at the unregulated sites in December 2003, but with the major channel changes that took place in the reservoir in water year 2003, there was little opportunity for large-scale erosion in 2004 as had occurred previously. Annual discharge was slightly decreased upstream of the reservoir in water year 2004, but slightly increased at VIDA.

Similarly, annual discharge at SFCO, upstream of Cougar Reservoir, was slightly lower (5 percent) in water year 2004 than in water year 2003 (table 4), but suspended-sediment load increased slightly (7 percent) (fig. 10). The large storm in April 2002 (see fig. 6) contributed to a much larger annual suspended-sediment load (6,800 tons) and average SSC (10.7 mg/L) upstream of Cougar Reservoir than in the following years, despite annual discharge being slightly lower than in 2003 and almost identical to that in 2004. This event illustrates the large potential annual variability at a given site even with annual discharges remaining equivalent. The event also occurred during the initial drawdown period at Cougar Reservoir, as discussed previously, and likely contributed to the increased release of suspended sediment from the reservoir to the McKenzie River in spring 2002, as a result of both increased incoming load and erosion of the newly exposed deltaic sediments in the upper reaches of the reservoir. 

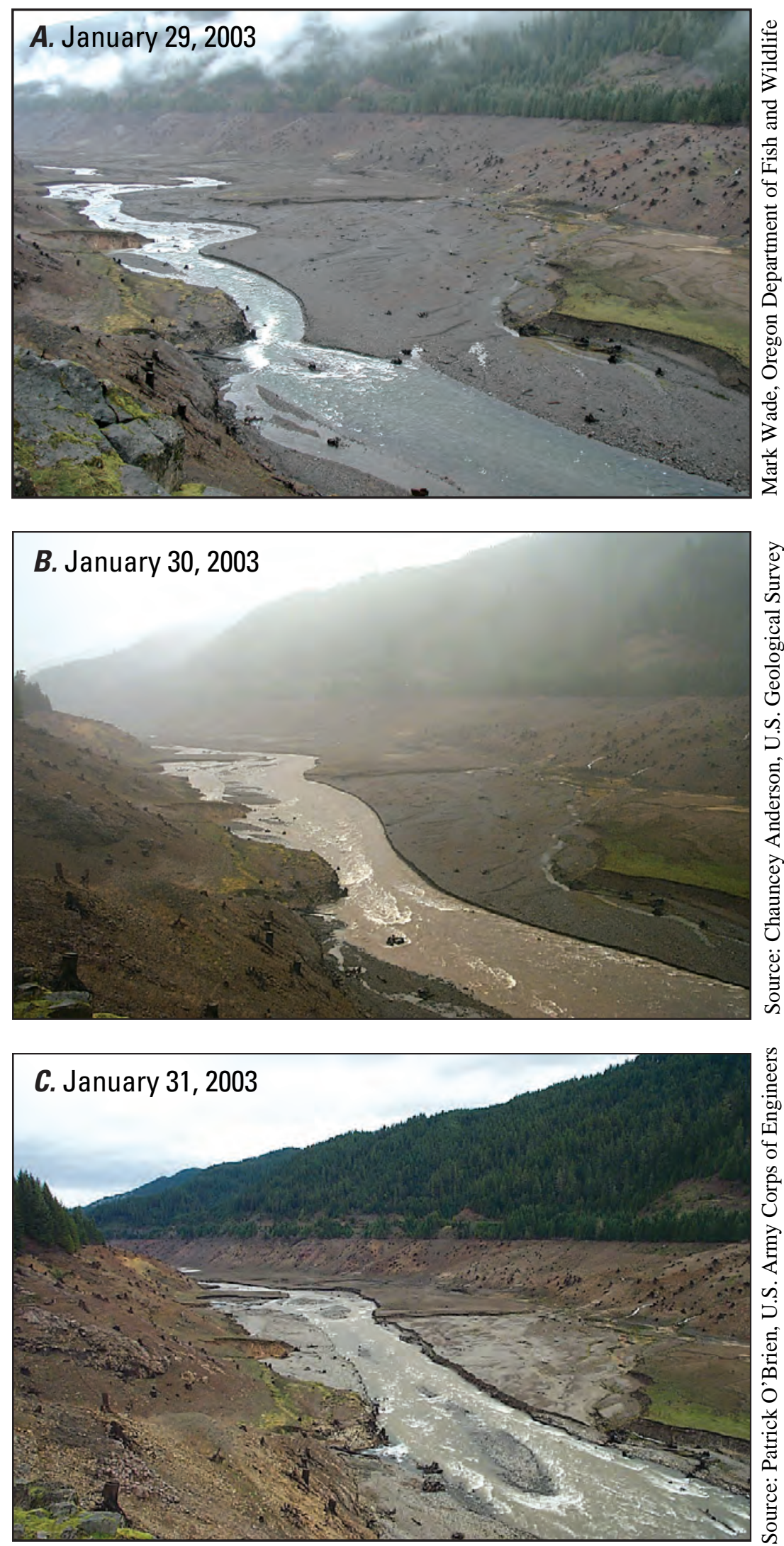

Figure 9. Channel changes in the South Fork McKenzie River within the Cougar Reservoir drawdown area, January 29-31, 2003, as seen from the Terwilliger Hot Springs parking area. The top, middle, and bottom photographs were taken January 29, January 30, and January 31, respectively. The sequence shows the migration of the channel away from the left bank and toward the center of the valley, with a straightening of meanders and additional downcutting. 


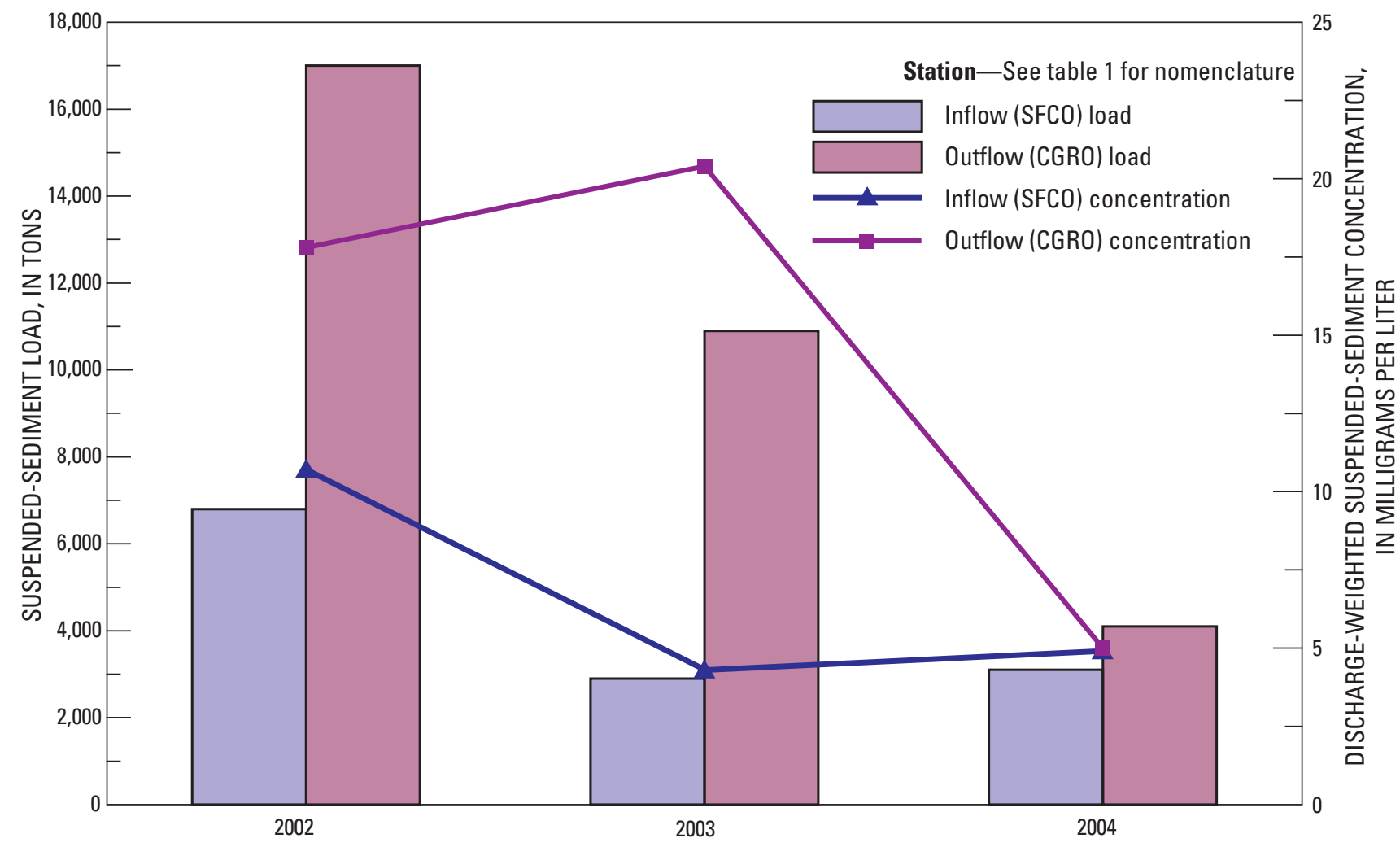

Figure 10. Annual load and discharge-weighted concentration of suspended sediment at the inflow to and outflow from Cougar Reservoir, Oregon.

Based on the differences in annual SSLs and dischargeweighted SSCs upstream and downstream of Cougar Reservoir (fig. 10), the reservoir evidently acted as a net sediment source during construction, particularly in 2002 and 2003. The difference between inflowing and outflowing loads was more than 10,000 tons in 2002 , decreasing to 8,000 and 1,000 tons in 2003 and 2004, respectively. Much of this increased export likely originated from the erosion of the streambed within the exposed delta areas. However, the exact amount of erosion cannot be determined from this analysis because it does not account for re-settling of sediments within the remaining reservoir pool near the dam, nor would it differentiate between other potential sources, such as the Rush Creek diversion failure or slumping and resuspension from the reservoir's steep side slopes.
Annual discharge-weighted SSC estimates, which also are corrected for partial records in table 4, provide another means for comparison. During most years, discharge-weighted SSC was lowest at the unregulated stations, MRBO and SFCO (around 2-3 and 4-6 mg/L, respectively, disregarding 2002 at SFCO), the regulated stations, CGRO and BLUE, had the highest concentrations, and those at VIDA were intermediate or similar to unregulated stations. The high annual SSC at CGRO during water year 2003 is partly a result of the large spike in SSC from the Rush Creek Diversion failure in January 2003 , together with the substantially decreased discharge from the reservoir during that year. During 2004, when the newly formed channels through the exposed arms of the reservoir had apparently stabilized, the discharge-weighted annual SSCs entering and exiting Cougar Reservoir from stations SFCO 
and CGRO were equivalent (4.9 and $5.0 \mathrm{mg} / \mathrm{L}$, respectively (fig. 10)), indicating the overall suspended-sediment contribution from Cougar Reservoir to the mainstem had been decreased to essentially background concentrations. However, on the basis of the previous discussion and data in table 2, the suspended sediment exiting Cougar Reservoir most likely had a higher percentage of fine material than did the suspended sediment entering the reservoir.

From a mass-balance standpoint, the monitoring network provided a reasonably complete accounting of the water sources in the study area and provides an opportunity to examine sources and fate of transported sediment. However, the late start to turbidity and SSC monitoring prevents a thorough estimate of deposition and transport during water year 2002, the initial year of the construction project and likely the most affected. Using water year 2004 as a test case, because it is the only water year with complete record at all sites, the sum of upstream annual discharges from MRBO, CGRO, and BLUE was 2,673,700 acre-ft (or $3.3 \times 10^{9}$ cubic meters). This is within 3 percent of the measured annual discharge of 2,743,000 acre-ft at VIDA (table 4). The most significant unmeasured inflow between the South Fork McKenzie River and the VIDA gaging station is Quartz Creek, a Western Cascades tributary on the south side of the river that generally has low flows but can swell during rainstorms to relatively high flows. Quartz Creek is likely the source of most of the 3-percent difference in summed discharges compared to that measured at VIDA.

In contrast to the 3-percent difference in measured, compared to summed, discharge at VIDA, the difference in suspended-sediment load from measured (16,900 tons) and summed (13,100 tons) estimates at VIDA is about 23 percent during water year 2004 (table 4). The difference is positive, indicating either unmeasured sources of suspended-sediment load between MRBO and VIDA, or that the errors in turbidity-SSC relations underestimate the upstream sources, overestimate the load at VIDA, or a combination of both. Deposition of the transported load in the reach between the South Fork and VIDA was apparently not significant during water year 2004, which is reasonable considering that stream velocities are relatively high in that reach and that suspended sediment measured at CGRO, BLUE, and VIDA tended to have relatively high fractions of fine material (medians 93,
91, and 85 percent, respectively). Quartz Creek may be a disproportionately large source of suspended sediment during winter rains, as there are large areas within the drainage basin that have been clear-cut and are potentially subject to erosion. The turbidity-SSC relations do not have as many data points as was initially desired, particularly at MRBO and BLUE, in part because of a lack of appropriate storms during the study period, so turbidity-based estimates of SSC could be biased low at the upstream sites or high at VIDA.

Similar conclusions may be drawn by using the partial record (January 29-September 30) from 2003 shown in table 4. The sum of upstream discharges from MRBO, CGRO, and BLUE $(1,688,800$ acre-ft) is within 7 percent of the partial-year discharge at VIDA, whereas the sum of upstream suspended-sediment loads is 32 percent less than the load at VIDA. These discrepancies indicate a possible sediment source, as opposed to large-scale deposition, between MRBO and VIDA. The partial-year suspended-sediment load from CGRO (about 7,400 tons) accounts for about 37 percent of the load measured at VIDA (about 20,000 tons) during the same period.

\section{DDT in Transport}

Sampling for $\Sigma$ DDx and other organochlorine compounds in transport was conducted during three storms: February 3, March 7-8, and December 13-15, 2003 (table 5). Organochlorines were not detected in any water samples (whole-water or suspended sediment only). However, Practical Quantitation Limits (PQL-see U.S. Environmental Protection Agency, 2006) were variable, ranging from relatively low (less than $0.0005 \mu \mathrm{g} / \mathrm{L})$ to relatively high $(0.0052 \mu \mathrm{g} / \mathrm{L})$. These concentrations are equal to 0.5-5.2 parts per trillion. Considering that the USEPA aquatic-life criterion is $0.001 \mu \mathrm{g} / \mathrm{L}$, or 1 part per trillion, analysis of some of these samples had decreased likelihood of detecting $\Sigma$ DDx , especially when turbidities were relatively low; however, when turbidities were high, the increased mass of sediment in the water column would be expected to carry more sorbed $\Sigma$ DDx, and the likelihood of detection increased. No other organochlorine compounds were detected in any storm samples (appendix B). 
Table 5. Concentrations of suspended sediment, suspended organic carbon, and DDT and metabolites transported during storms in the McKenzie River basin, Oregon, 2003.

[Water chemistry was analyzed at Severn Trent Laboratory in Seattle, WA, except suspended particulate carbon, which was analyzed at the U.S. Geological Survey's National Water Quality Laboratory in Denver, CO, and suspended-sediment concentrations, which were analyzed at the Cascades Volcano Observatory Sediment Lab in Vancouver, WA. Abbreviations: DDD, dichloro-diphenyl-dichloroethane; DDE, dichloro-diphenyldichloroethene; DDT, dichloro-diphenyl-trichloroethane; FNU, Formazin Nephelometric Units; MDL, method detection limit, defined by USEPA as "the minimum concentration of a substance that can be reported with 99 percent confidence that the analyte concentration is greater than zero" (40 CFR Part 136 Appendix B); PQL, Practical Quantitation Limit, the lowest concentration of an analyte that can be reliably measured within specified limits of precision and accuracy during routine laboratory operating conditions (50 FR 46906); mm, millimeter; mg/L, milligram per liter; $\mu \mathrm{g} / \mathrm{L}$, microgram per liter; -, no data; ND, not detected]

\begin{tabular}{|c|c|c|c|c|c|c|c|c|}
\hline Station name & Date & Time & $\begin{array}{l}\text { Turbidity } \\
\text { (FNU) }\end{array}$ & $\begin{array}{c}\text { Suspended } \\
\text { sediment } \\
\text { (mg/L) }\end{array}$ & $\begin{array}{c}\text { Fine } \\
\text { sediment } \\
\text { (percent } \\
<0.063 \mathrm{~mm} \text { ) }\end{array}$ & $\begin{array}{c}\text { Suspended } \\
\text { particulate } \\
\text { carbon } \\
(\mathrm{mg} / \mathrm{L})\end{array}$ & $\begin{array}{l}\text { Dissolved } \\
\text { organic } \\
\text { carbon } \\
\text { MDL (mg/L) }\end{array}$ & $\begin{array}{c}\text { Dissolved } \\
\text { organic } \\
\text { carbon } \\
\text { (mg/L) }\end{array}$ \\
\hline \multirow{2}{*}{$\begin{array}{l}\text { McKenzie River above South Fork, near } \\
\text { Rainbow (MRBO) }\end{array}$} & 03-08-02 & $11: 10$ & 1.6 & 4 & - & - & 0.35 & 2.2 \\
\hline & $12-14-03$ & $11: 30$ & 8.2 & 17 & 63 & - & - & - \\
\hline \multirow{2}{*}{$\begin{array}{l}\text { South Fork McKenzie River above Cougar } \\
\text { Reservoir, near Rainbow (SFCO) }\end{array}$} & 03-08-03 & $16: 30$ & 2.4 & 6 & 42.9 & - & .35 & 2.1 \\
\hline & $12-13-03$ & $15: 30$ & 91.4 & 310 & 45.6 & 18 & .5 & 2.5 \\
\hline \multirow{3}{*}{$\begin{array}{l}\text { South Fork McKenzie River near Rainbow } \\
\text { (CGRO) }\end{array}$} & $02-03-03$ & $16: 50$ & 74.5 & 50 & 95.9 & 6 & .35 & 1.8 \\
\hline & 03-08-03 & $13: 35$ & 5.8 & 4 & 96.9 & - & .35 & 3.9 \\
\hline & $12-14-03$ & $14: 20$ & 112.7 & 88 & 96.5 & 1.8 & .5 & .8 \\
\hline Blue River at Blue River (BLUE) & $12-15-03$ & 13:40 & 44.7 & 30 & 98 & - & - & - \\
\hline \multirow[t]{2}{*}{ McKenzie River near Vida (VIDA) } & $02-03-03$ & $12: 50$ & 26.2 & 18 & 90.7 & .3 & .35 & 1.8 \\
\hline & $12-14-03$ & $8: 50$ & 26.5 & 25 & 82.9 & - & - & - \\
\hline $\begin{array}{l}\text { McKenzie River at Hayden Bridge, near } \\
\text { Springfield }\end{array}$ & $12-15-03$ & $16: 20$ & 36.1 & 47 & 70.8 & .9 & .5 & 1.9 \\
\hline
\end{tabular}

\begin{tabular}{|c|c|c|c|c|c|c|c|c|}
\hline \multicolumn{9}{|c|}{ DDT and Metabolites in Whole Water } \\
\hline Station name & Date & Time & $\begin{array}{c}\text { DDD } \\
\text { PQL } \\
(\mu \mathrm{g} / \mathrm{L})\end{array}$ & $\begin{array}{c}\text { DDD } \\
\text { results } \\
(\mu \mathrm{g} / \mathrm{L})\end{array}$ & $\begin{array}{c}\text { DDE } \\
\text { POL } \\
(\mu \mathrm{g} / \mathrm{L})\end{array}$ & $\begin{array}{c}\text { DDE } \\
\text { results } \\
(\mu \mathrm{g} / \mathrm{L})\end{array}$ & $\begin{array}{c}\text { DDT } \\
\text { POL } \\
(\mu \mathrm{g} / \mathrm{L})\end{array}$ & $\begin{array}{c}\text { DDT } \\
\text { results } \\
(\mu \mathrm{g} / \mathrm{L})\end{array}$ \\
\hline $\begin{array}{l}\text { McKenzie River above South Fork, near } \\
\text { Rainbow (MRBO) }\end{array}$ & $\begin{array}{l}03-08-02 \\
12-14-03\end{array}$ & $\begin{array}{l}11: 10 \\
11: 30\end{array}$ & $\begin{array}{r}0.0005 \\
.0022\end{array}$ & $\begin{array}{l}\text { ND } \\
\text { ND }\end{array}$ & $\begin{array}{r}0.0004 \\
.0022\end{array}$ & $\begin{array}{l}\text { ND } \\
\text { ND }\end{array}$ & $\begin{array}{r}0.0005 \\
.0022\end{array}$ & $\begin{array}{l}\text { ND } \\
\text { ND }\end{array}$ \\
\hline $\begin{array}{l}\text { South Fork McKenzie River above Cougar } \\
\text { Reservoir, near Rainbow (SFCO) }\end{array}$ & $\begin{array}{l}03-08-03 \\
12-13-03\end{array}$ & $\begin{array}{l}16: 30 \\
15: 30\end{array}$ & $\begin{array}{l}.0005 \\
.0022\end{array}$ & $\begin{array}{l}\text { ND } \\
\text { ND }\end{array}$ & $\begin{array}{l}.0004 \\
.0022\end{array}$ & $\begin{array}{l}\text { ND } \\
\text { ND }\end{array}$ & $\begin{array}{l}.0005 \\
.0022\end{array}$ & $\begin{array}{l}\text { ND } \\
\text { ND }\end{array}$ \\
\hline $\begin{array}{l}\text { South Fork McKenzie River near Rainbow } \\
\text { (CGRO) }\end{array}$ & $\begin{array}{l}02-03-03 \\
03-08-03 \\
12-14-03\end{array}$ & $\begin{array}{l}16: 50 \\
13: 35 \\
14: 20\end{array}$ & $\begin{array}{l}.0005 \\
.0005 \\
.0020\end{array}$ & $\begin{array}{l}\text { ND } \\
\text { ND } \\
\text { ND }\end{array}$ & $\begin{array}{l}.0004 \\
.0004 \\
.0020\end{array}$ & $\begin{array}{l}\text { ND } \\
\text { ND } \\
\text { ND }\end{array}$ & $\begin{array}{l}.0005 \\
.0006 \\
.0020\end{array}$ & $\begin{array}{l}\mathrm{ND} \\
\mathrm{ND} \\
\mathrm{ND}\end{array}$ \\
\hline Blue River at Blue River (BLUE) & $12-15-03$ & $13: 40$ & .0024 & ND & .0024 & ND & .0024 & ND \\
\hline McKenzie River near Vida (VIDA) & $\begin{array}{l}02-03-03 \\
12-14-03\end{array}$ & $\begin{array}{r}12: 50 \\
8: 50\end{array}$ & $\begin{array}{l}.0049 \\
.0021\end{array}$ & $\begin{array}{l}\text { ND } \\
\text { ND }\end{array}$ & $\begin{array}{l}.0040 \\
.0021\end{array}$ & $\begin{array}{l}\text { ND } \\
\text { ND }\end{array}$ & $\begin{array}{l}.0052 \\
.0021\end{array}$ & $\begin{array}{l}\text { ND } \\
\text { ND }\end{array}$ \\
\hline $\begin{array}{l}\text { McKenzie River at Hayden Bridge, near } \\
\text { Springfield }\end{array}$ & $12-15-03$ & $16: 20$ & .0021 & ND & .0021 & ND & .0021 & ND \\
\hline \multicolumn{9}{|c|}{ DDT and Metabolites in Suspended Sediment } \\
\hline Station name & Date & Time & $\begin{array}{c}\text { DDD } \\
\text { POL } \\
(\mu \mathrm{g} / \mathrm{L})\end{array}$ & $\begin{array}{c}\text { DDD } \\
\text { results } \\
(\mu \mathrm{g} / \mathrm{L})\end{array}$ & $\begin{array}{c}\text { DDE } \\
\text { POL } \\
(\mu \mathrm{g} / \mathrm{L})\end{array}$ & $\begin{array}{c}\text { DDE } \\
\text { results } \\
(\mu \mathrm{g} / \mathrm{L})\end{array}$ & $\begin{array}{c}\text { DDT } \\
\text { POL } \\
(\mu \mathrm{g} / \mathrm{L})\end{array}$ & $\begin{array}{c}\text { DDT } \\
\text { results } \\
\text { ( } \mu \mathrm{g} / \mathrm{L})\end{array}$ \\
\hline $\begin{array}{l}\text { McKenzie River above South Fork, near } \\
\text { Rainbow (MRBO) }\end{array}$ & $\begin{array}{l}03-08-02 \\
12-14-03\end{array}$ & $\begin{array}{l}11: 10 \\
11: 30\end{array}$ & - & $\begin{array}{l}- \\
-\end{array}$ & - & - & - & - \\
\hline $\begin{array}{l}\text { South Fork McKenzie River above Cougar } \\
\text { Reservoir, near Rainbow (SFCO) }\end{array}$ & $\begin{array}{l}03-08-03 \\
12-13-03\end{array}$ & $\begin{array}{l}16: 30 \\
15: 30\end{array}$ & $\begin{array}{c}- \\
0.0008\end{array}$ & $\begin{array}{c}- \\
\mathrm{ND}\end{array}$ & $\begin{array}{c}- \\
0.0008\end{array}$ & $\begin{array}{c}- \\
\mathrm{ND}\end{array}$ & $\begin{array}{c}- \\
0.0008\end{array}$ & $\begin{array}{c}- \\
\mathrm{ND}\end{array}$ \\
\hline $\begin{array}{l}\text { South Fork McKenzie River near Rainbow } \\
\text { (CGRO) }\end{array}$ & $\begin{array}{l}02-03-03 \\
03-08-03 \\
12-14-03\end{array}$ & $\begin{array}{l}16: 50 \\
13: 35 \\
14: 20\end{array}$ & $\begin{array}{c}.002 \\
- \\
.0006\end{array}$ & $\begin{array}{c}\text { ND } \\
- \\
\text { ND }\end{array}$ & $\begin{array}{c}.0017 \\
- \\
.0006\end{array}$ & $\begin{array}{c}\text { ND } \\
- \\
\text { ND }\end{array}$ & $\begin{array}{c}.0021 \\
- \\
.0006\end{array}$ & $\begin{array}{c}\mathrm{ND} \\
- \\
\mathrm{ND}\end{array}$ \\
\hline Blue River at Blue River (BLUE) & $12-15-03$ & $13: 40$ & - & - & - & - & - & - \\
\hline McKenzie River near Vida (VIDA) & $\begin{array}{l}02-03-03 \\
12-14-03\end{array}$ & $\begin{array}{r}12: 50 \\
8: 50\end{array}$ & $\begin{array}{l}.0001 \\
.0008\end{array}$ & $\begin{array}{l}\text { ND } \\
\text { ND }\end{array}$ & $\begin{array}{l}.0001 \\
.0008\end{array}$ & $\begin{array}{l}\text { ND } \\
\text { ND }\end{array}$ & $\begin{array}{l}.0001 \\
.0008\end{array}$ & $\begin{array}{l}\mathrm{ND} \\
\mathrm{ND}\end{array}$ \\
\hline $\begin{array}{l}\text { McKenzie River at Hayden Bridge, near } \\
\text { Springfield }\end{array}$ & $12-15-03$ & $16: 20$ & - & - & - & - & - & - \\
\hline
\end{tabular}




\section{Sediment Deposition into Streambed Sediment}

At least one infiltration bag was retrieved intact from each location, and more than one in two cases. Issues preventing all bags from being retrieved intact included lost bags and retrieval cables that broke during the process of winching the bags out of the bed. One bag, from South Fork McKenzie River above Cougar Reservoir (SFCO), was found downstream during the deployment period following the large storm of December 13, 2003. During this storm, rocks and boulders were audibly being moved and large logs were being transported downstream at SFCO. The streambed likely was mobilized at this site, thus ripping the infiltration bag from its deployed position. Another bag from the same location was never found, despite the use of a metal detector, although it is unknown whether it too was ripped out of the bed or if aggradation and bed movement had merely buried its retrieval cables. During the initial retrievals, some cables broke, having rusted during the deployment period, and the bags could only be retrieved by digging them up which disturbed the bed and rendered the results qualitative. In order to retrieve the remaining infiltration bags without breaking the cables, a tension equalizer was devised that equally distributed the force from the tripod-mounted winch into each cable.

Subsequent extractions were all successful with this device employed. Future deployments of infiltration bags will have a greater chance of successful retrieval if stronger cables (threesixteenths or quarter-inch, stainless steel) are used.

The mass and percentage of all sediment, fine sediment, and $\Sigma$ DDx in each is shown in table 6. The total mass of sediment retrieved ranged from about 23 to 43 kilograms (or about 51-95 pounds) among all bags, with the lowest amount at SFCO and the highest at MRBO. Amounts of sand and smaller $(<2 \mathrm{~mm}$ in diameter) material ranged from 3 to 14 percent by weight among all bags, and fine material (silt and clay fractions, $<0.063 \mathrm{~mm}$ in diameter) ranged from about 65 to 415 grams (0.14-0.91 pounds), or 0.2-1.2 percent by weight, among all bags. Where two or more bags were retrieved, replication of sediment concentrations was good; at VIDA, standard deviations of the total fines and

Table 6. Total mass of sediment and percent of fine materials, and concentrations of DDT and metabolites, in infiltration bags deployed in the McKenzie River, Oregon, August 2003-July 2004.

[Infiltration bags that were not quantitatively retrieved are not shown, except where qualitative data on DDT and its metabolites are available. Abbreviations: mg/L, milligram per liter; mg, milligram; mm, millimeter; g, gram; $\mu \mathrm{g} / \mathrm{kg}$, microgram per kilogram; DDD, dichloro-diphenyl-dichloroethane; DDE, dichlorodiphenyl-dichloroethene; DDT, dichloro-diphenyl-trichloroethane; ND, Not Detected; MDL, method detection limit, defined by USEPA as "the minimum concentration of a substance that can be reported with 99 percent confidence that the analyte concentration is greater than zero" (40 CFR Part 136 appendix B); - , no data; <, less than]

\begin{tabular}{|c|c|c|c|c|c|c|c|c|c|c|}
\hline \multirow{2}{*}{ Station ID } & \multirow{2}{*}{ Sample } & \multirow{2}{*}{$\begin{array}{c}\text { Suspended- } \\
\text { sediment } \\
\text { concentration } \\
\text { (mg/L) }\end{array}$} & \multirow{2}{*}{$\begin{array}{l}\text { Total mass } \\
\text { of sediment } \\
\text { (g) }\end{array}$} & \multirow{2}{*}{$\begin{array}{l}\text { Percent } \\
<2 \mathrm{~mm} \text { in } \\
\text { trap }\end{array}$} & \multirow{2}{*}{$\begin{array}{c}\text { Total fines } \\
(<0.063 \mathrm{~mm}) \\
(\mathrm{g})\end{array}$} & \multirow{2}{*}{$\begin{array}{c}\text { Percent } \\
\text { fines, by } \\
\text { weight } \\
\text { (<0.063 mm) }\end{array}$} & \multicolumn{4}{|c|}{$\begin{array}{l}\text { DDT concentrations, in } \\
\text { micrograms per kilogram }\end{array}$} \\
\hline & & & & & & & $\begin{array}{l}\text { p,p' } \\
\text { DDD }\end{array}$ & $\begin{array}{l}\text { p,p' } \\
\text { DDE }\end{array}$ & $\begin{array}{l}\text { p,p' } \\
\text { DDT }\end{array}$ & $\begin{array}{l}\text { Total DDT } \\
\text { MDL }\end{array}$ \\
\hline MRBO & Surface & 1.4 & & & & 43 & & & & \\
\hline MRBO \#1 & Trap 1 & & 37,385 & 11.9 & 91 & .2 & ND & $\mathrm{ND}$ & ND & $<3.42$ \\
\hline MRBO \#2 & $\begin{array}{l}\text { Trap } 2 \\
\text { Average } \\
\text { SD }\end{array}$ & & $\begin{array}{l}43,609 \\
40,497 \\
4,401.0\end{array}$ & $\begin{array}{r}9.5 \\
10.7 \\
1.7\end{array}$ & $\begin{array}{l}93 \\
92 \\
.8\end{array}$ & $\begin{array}{l}.2 \\
.2 \\
.02\end{array}$ & - & - & - & - \\
\hline SFCO & Surface & 0.8 & & & & 25 & & & & \\
\hline SFCO \#1 & Trap 1 & & 23,369 & 12.2 & 65 & .3 & ND & ND & ND & $<6.86$ \\
\hline CGRO & Surface & 1.6 & & & & 75 & & & & \\
\hline CGRO \#1 & Trap 1 & & 37,558 & 3.3 & 384 & 1.0 & 0.184 & 2.40 & ND & 1.53 \\
\hline BLUE \#3 & Trap 3 & & 26,355 & 6.2 & 415 & 1.2 & - & - & - & - \\
\hline VIDA & Surface & 0.6 & & & & 33 & & & & \\
\hline VIDA \#1 & Trap 1 & & 36,110 & 14.2 & 197 & .5 & - & - & - & - \\
\hline VIDA \#2 & Trap 2 & & 34,339 & 11.9 & 216 & .6 & ND & 1.93 & ND & $<1.778$ \\
\hline VIDA \#3 & $\begin{array}{l}\text { Trap } 3 \\
\text { Average } \\
\text { SD }\end{array}$ & & $\begin{array}{r}35,259 \\
35,236 \\
885.7\end{array}$ & $\begin{array}{r}10.0 \\
12.0 \\
2.1\end{array}$ & $\begin{array}{r}226 \\
213 \\
15.2\end{array}$ & $\begin{array}{l}.6 \\
.6 \\
.1\end{array}$ & - & - & - & - \\
\hline
\end{tabular}


percent fines were about 15.2 grams $(\mathrm{g})$ and 0.1 percent, or 7.1 and 16 percent of the averages, respectively; at MRBO the relative differences were $0.8 \mathrm{~g}$ and 0.02 percent, or about 0.9 and 9 percent of average, respectively. These results indicate that the method is sound and that variability of fine sediment deposition within a given area of similar hydraulic and geomorphological properties is low compared to variability between sites.

Although stream velocity may be an important factor contributing to deposition into the streambed, data were unavailable to fully assess the velocity differences among sites, particularly at high flows. At low flow, during deployment and retrieval periods for the infiltration bags, stream velocities were likely similar among sites because all sites were selected on the basis of a set of similar characteristics. These included maximum depths of 10-13 cm, and gravel beds at the head of a small riffle where downwelling would be likely. During high-flow periods, velocity differences among sites were undoubtedly important, on the basis of differences in peak flows and the gradients of the streams in different locations, as well as the moderating effect on flow and velocities exerted by Blue and Cougar Reservoirs. Data on 5 DDx were insufficient to assess method variability because of the lack of detections.

Despite the low variability of the deposited fine material within an individual site, variability was substantial among site types. Fine sediment $(<0.063 \mathrm{~mm})$ generally constituted less than 0.3 percent (about $0.23-0.28$ percent) of the sediment in the infiltration bag at unregulated sites (MRBO and SFCO), but was greater than 1 percent at sites downstream of reservoirs, with the greatest deposition (1.2 percent) occurring at Blue River downstream of Blue River Reservoir (BLUE) (table 6, fig. 11). Deposition at VIDA (0.6 percent) was intermediate to that at the regulated and unregulated sites, which is consistent with the fact that it is located just a few miles downstream of the mouths of both Blue River and the South Fork McKenzie River. Apparently the sediment regime at VIDA was strongly influenced by sediment loads from the South Fork and from Blue River during the study period. In contrast to fine materials, more sand- and smallersized sediment $(<2 \mathrm{~mm})$ was observed in infiltration bags from unregulated sites ( 9 to 12 percent) than at the regulated sites (about 3 to 6 percent). Deposition of $<2$-mm sediment in infiltration bags at VIDA was similar to unregulated sites (about 10-14 percent).

DDD and DDE were detected in deposited sediment from infiltration bags downstream of Cougar Reservoir, in concentrations of about $0.18-2.4$ nanograms per liter (ng/L, or parts per trillion) and on the mainstem at VIDA (1.93 ng/L). This included sediment from one infiltration bag (CGRO) that had to be dug out manually due to broken retrieval cables, and which is therefore treated as qualitative from the standpoint of determining a total mass of $\Sigma D D x$ in the infiltration bag.

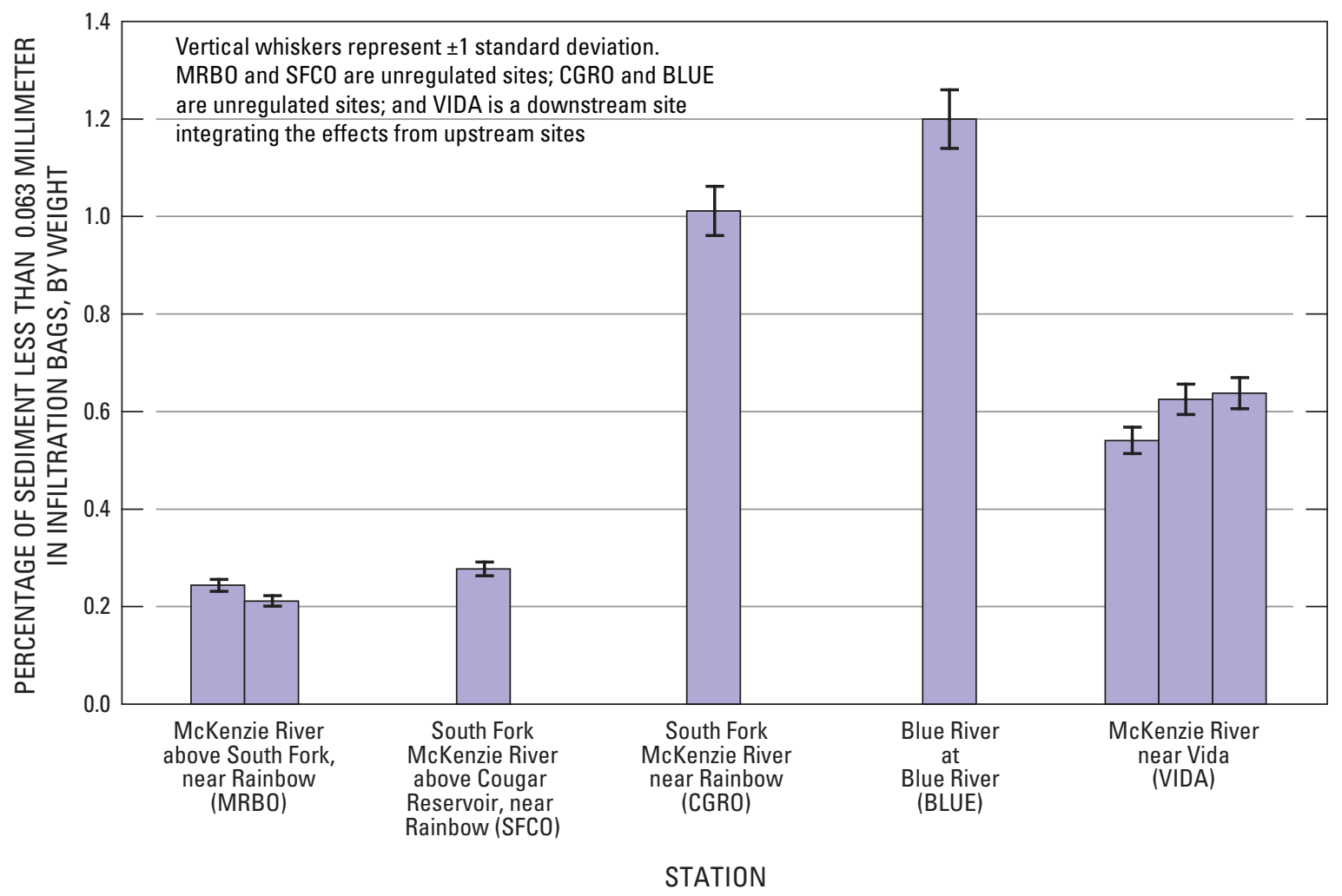

Figure 11. Percentage of sediment less than 0.063 millimeters in diameter in infiltration bags after 1 year deployment in the McKenzie River, Oregon, 2004. 
None of the parent compound, DDT, was detected in either of these samples, in contrast to the findings of the USACE's initial sampling of streambank and lakebed sediments in which an average of about 15 percent of the detected $\Sigma D D x$ was as DDT (U.S. Army Corps of Engineers, 2003). No other organochlorine compounds were detected in any samples (appendix C).

\section{Influence of Drawdown on Sediment and DDT Transport and Deposition}

Owing to a lack of sufficient high-turbidity events and suspended-sediment samples, only limited interpretations can be inferred from the turbidity-SSC correlations. First, with the exception of CGRO and to a lesser extent SFCO, the slope of the regression lines may be biased by a few individual samples such that additional samples might have produced substantially different estimates of concentrations, and therefore average and annual load estimates, on the basis of monitored turbidity. Second, estimation of concentration during several events from most sites is based on extrapolation of regression equations at turbidities beyond the maximums sampled, and so may not adequately account for differential sources or character of suspended sediment at those high concentrations and flows. Third, the turbidity and SSC sampling network in place during spring and summer 2002, the period of highest turbidity release from Cougar Reservoir, was not adequate to evaluate the potential effects on the mainstem McKenzie River.

Nevertheless, releases from Cougar Reservoir apparently were the primary source of suspended sediment to the mainstem during 2002-03, although full quantification of that contribution and its effect on deposition in the mainstem is not possible with the available data. Loads entering the reservoir were less than one-half of those exiting the reservoir during 2002 and 2003, and about 75 percent in 2004. Blue River Reservoir, although releasing a relatively high suspendedsediment concentration (annual discharge weighted average greater than $8 \mathrm{mg} / \mathrm{L}$ ), has relatively low flow, so the loads were reduced in comparison to those from Cougar, and the water from upstream on the McKenzie River was relatively clear, so loads were kept small despite discharge being more than three times higher than those released from Cougar Reservoir. Data from 2003 and 2004 indicate that the reach between the South Fork and Vida was actually a source rather than a sink for suspended sediment. Deposition downstream of Vida (for example, in Leaburg Reservoir) could not be estimated on the basis of available data. Overall downstream sediment transport decreased during the course of the study as export from Cougar Reservoir declined with the equilibration of the exposed stream channels. Thus, even though large storm events in water year 2004 resulted in elevated loads at upstream, unregulated sites, the loads at CGRO and VIDA were reduced compared to previous years.

Furthermore, the flood-control reservoirs in the McKenzie River basin apparently act as traps for large particles and preferentially allow smaller, fine material to pass through to downstream reaches. In the South Fork, upstream erosion of the exposed deltaic sediments in Cougar Reservoir during the drawdown period caused mobilization of several decades' worth of deposited fine sediment and clays. However, this also apparently occurs annually, albeit to a lesser extent, in Blue River Reservoir, where the annual winter reservoir drawdown results in an elevated baseline turbidity. Evidence for this sediment fractionation process is threefold: (1) SSC samples at regulated sites (CGRO and BLUE, below Cougar and Blue River Reservoirs, respectively) were composed of a substantially high percentage of fine material than samples from the unregulated sites (on the basis of a relatively small number of samples), (2) the slopes of the turbidity-SSC regressions are lower for the regulated sites than unregulated sites (SFCO and MRBO), indicating that a lower concentration of suspended sediment is being transported per unit of turbidity at those sites, and (3) infiltration bag results indicated that deposition of fine material was greater at regulated than at unregulated sites during the 1-year deployment period.

One factor that may partially explain the high accumulation of fine sediment in infiltration bags at regulated compared to unregulated sites is the relative frequency of bed-moving events. The storm of December 13, 2003, and possibly one or two others, caused mobilization of large rocks, trees, and some reconfiguration of gravel beds at the most unregulated sites (SFCO and MRBO). During such events, fine sediments that have been lodged in the interstices of gravel beds would likely be scoured from the streambed, remobilized, and transported downstream, thus reducing overall accumulation of fine sediment. At the regulated sites (BLUE and CGRO), scouring flows were not experienced and typically are not during even the largest midwinter storms, because the reservoirs' intended function is to decrease stormwater peaks, metering the peak flow to downstream reaches more slowly. Therefore, deposited fine sediments in the reaches downstream of the flood-control reservoirs are not scoured annually and the fine material can better accumulate within the pore spaces. If reservoir outflows can be manipulated to produce periodic pulses of high flow during periods when downstream flooding is not a concern and when the reservoir outflows are relatively sediment free (that is, SSLs entering the reservoirs are small), it might be possible to mobilize the streambed enough to decrease accumulation of fine sediment. Blue River Reservoir typically released higher turbidity water than Cougar Reservoir during winter baseflow (nonstorm) periods (U.S. Geological Survey, 2003, 2004), which is one reason that deposition at BLUE may have 
been so much higher than at any of the other sites. Therefore, mobilization of the bed downstream of Blue River Reservoir might be particularly effective.

Deposition of fine material as determined from infiltration bags is best considered a relative measurement rather than an absolute deposition rate, because the streambed above and immediately surrounding the bag (an area with radius approximately three to four times the radius of the infiltration bag) is thoroughly disturbed during the burial process. The use of experimental rocks and gravel allows for more direct comparison between individual bags and between sites than would the use of native gravel. Given that the median diameter of the experimental gravel was mostly similar to that of native gravel, the porosity of the freshly installed experimental gravel is assumed to be substantially higher than in undisturbed native gravel. Thus, the pore spaces would be more susceptible to additional accumulation of fine sediment during the subsequent deployment period; therefore, deposition rates of fine material derived from infiltration bags probably are overestimates of actual, recent deposition rates in native gravels in the McKenzie River. By comparison, the freeze cores extracted by Gregory Stewart and others (Oregon State University, unpub. data, 2002) may provide an upper bound of long-term (and recent) deposition of fine material, but without resolution of recent deposition rates.

Findings from the infiltration bags indicated increased deposition of silts and clays $(<0.063-\mathrm{mm}$ fraction) and decreased deposition of sand at regulated sites as compared to the unregulated sites in 2003-04. For the most part, this was similar to the findings from freeze cores collected in 2002 shortly after the reservoir drawdown (table 7, fig. 12), although the amount of sand in freeze cores was somewhat higher at all sites except SFCO (Gregory Stewart and others, unpub. data, 2002). In the freeze cores, the less-than-2-mm fraction was as high as 18 percent at the unregulated site MRBO as compared to about 14 percent at the regulated CGRO during 2002. However, they found only 3.8 percent of the less-than-2-mm fraction at SFCO. Freeze cores were not collected in Blue River.

Table 7. Comparison of fine material deposition in McKenzie River bed sediment measured from freeze cores during July 2002 and infiltration bags deployed from August 2003-July 2004.

[Location: this study/Steward and others, unpublished. Sediment amounts are expressed as a percent of the bulk material, by weight, in the indicated size fractions. Freeze core data are from bins B \& C, as reported by Stewart and others (unpublished). Sampling locations for the infiltration bags and freeze cores were identical for the sites on the South Fork McKenzie and the main stem above the South Fork, but were different on the main stem below the South Fork, where the USGS site for infiltration bags was upstream from MS2. Values given are averages and standard deviations (in parenthesis) where possible. Abbreviations: mm, millimeter; <, less than]

\begin{tabular}{|c|c|c|c|c|c|c|}
\hline \multirow[b]{2}{*}{ Location } & \multicolumn{6}{|c|}{ Percent of deposited sediment in indicated fraction } \\
\hline & \multicolumn{2}{|c|}{$\begin{array}{l}\text { Sand and smaller } \\
\qquad(<2 \mathrm{~mm})\end{array}$} & \multicolumn{2}{|c|}{$\begin{array}{l}\text { Silt and clay } \\
(<0.063 \mathrm{~mm})\end{array}$} & \multicolumn{2}{|c|}{$\begin{array}{l}\text { Silt and clay, } \\
\text { (as percent of sand) }\end{array}$} \\
\hline $\begin{array}{l}\text { McKenzie River above South Fork, } \\
\text { near Rainbow } \\
\text { MRBO / MS1 }\end{array}$ & $10.7(1.7)$ & $18.3(5.0)$ & $0.2(0.02)$ & $1.7(0.5)$ & $2.1(0.1)$ & $9.3(0.0)$ \\
\hline $\begin{array}{l}\text { South Fork McKenzie above Cougar Reservoir, } \\
\text { near Rainbow } \\
\text { SFCO / SFA2 (Bin C only) }\end{array}$ & 12.5 & 3.8 & .3 & .02 & 2.2 & $.5(.7)$ \\
\hline $\begin{array}{l}\text { South Fork McKenzie near Rainbow } \\
\text { CGRO / SFB2 }\end{array}$ & 3.3 & $14.4(10.2)$ & 1.0 & $2.4(1.8)$ & 30.3 & $17.3(8.0)$ \\
\hline
\end{tabular}




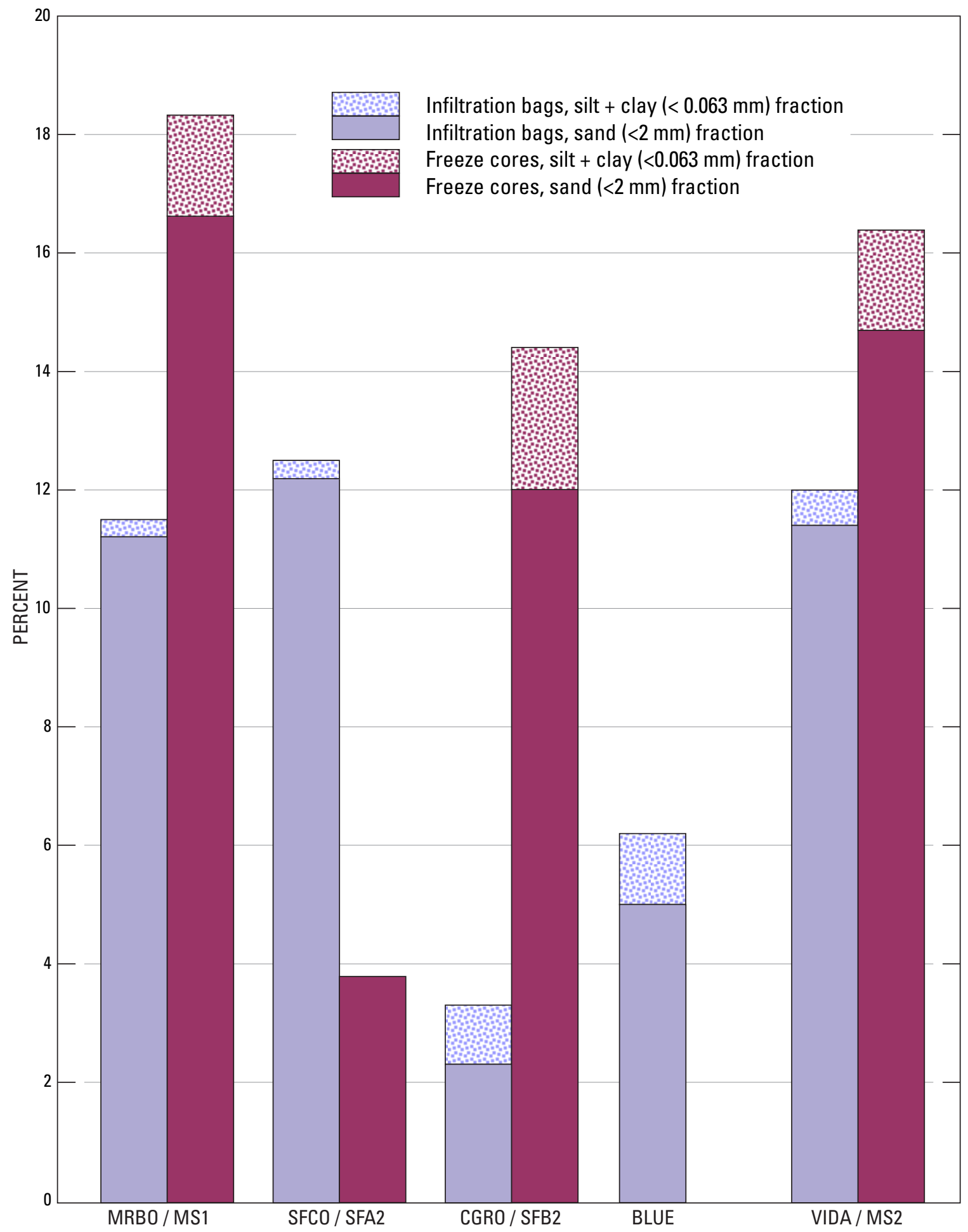

Figure 12. Relation of sand, silt, and clay fractions recovered from infiltration bags and freeze cores in the McKenzie River, Oregon. Infiltration bags (U.S. Geological Survey) were deployed August 2003-July 2004, and freeze cores (Oregon State University) were extracted in summer 2002. Site nomenclature is given in table 1. 
The pattern of enrichment in silt and clay $(<0.063 \mathrm{~mm})$ in infiltration bags at regulated sites also was similar to the findings in freeze cores (table 7, fig. 12), although fine fractions generally were lower in infiltration bags relative to the overall sample than the fine fractions in the freeze cores. However, expressed as a percentage of the $<2 \mathrm{~mm}$ fraction, the silt and clay proportions were quite similar in the two studies. The $<0.063 \mathrm{~mm}$ fraction constituted the smallest fraction of the $<2 \mathrm{~mm}$ material upstream of Cougar Reservoir and the highest downstream of Cougar Reservoir, and also was high downstream of Blue River Reservoir. In the Oregon State University study, variabilities in errors estimated from replicate freeze cores were 10 percent in clay and 50 percent in silt, and the fine fraction likely was underestimated by 8-50 percent, in part because of the dry-sieving method used (Sarah Lewis, Oregon State University, written commun., 2006).

Deposition of sand generally was decreased in infiltration bags at regulated sites during 2003-04 as compared to the freeze cores because sand was removed during the installation of the bags and was never replenished due to the trapping of sand and larger-sized particles in the reservoirs. In contrast, the freeze cores sampled native bed material that had been minimally disturbed in previous years, and high sand concentrations were likely to be the result of many years of accumulation. Although both the freeze cores and infiltration bag techniques attempt to evaluate sediment deposition in the bed, the two methods are fundamentally different. Freeze cores sample native sediments but with no ability to extrapolate to the time period during which deposition occurred, whereas infiltration bags used nonnative (experimental) sediments and had a well-constrained time of exposure. For the two methods to show similar patterns and generally similar fractions of sand and silt plus clay lends credence to the results of either method individually.

The deposition in the South Fork during 2003-04 probably was less than that during the drawdown period and subsequent winter, from spring 2002 to spring 2003, because average turbidities were not as high for a sustained period as immediately following the initial reservoir drawdown, during 2002 (fig. 6C). A reportedly thick, visible surface layer of settled, fine duff over the bed sediment at CGRO that was easily resuspended when disturbed and was observed during spring - summer 2002 (Doug Cushman, U.S. Geological Survey, oral commun., 2002) was not as evident during 2003-04. The same may be true in the mainstem McKenzie River downstream of the South Fork, which transported a prolonged plume of increased turbidity from the South Fork during 2002 (U.S. Army Corps of Engineers, 2003) but had only episodic periods of high turbidity following the largest events during 2003-04.
DDT and its metabolites were detected in deposited fine sediment in the streambed at CGRO and at VIDA, and concentrations were low. $\Sigma$ DDx was likely mobilized only during large storms, and, on the basis of turbidity measurements, may have been detectable only a few times in the water column during the course of the study, if at all. The greatest downstream transport period of $\Sigma \mathrm{DDx}$ would likely have occurred during April-June 2002, when turbidities were greater than $50 \mathrm{FNU}$ for most of May, with sporadic spikes of more than 100 FNU between April and June (appendix A); individual storms in January, February, and December 2003 were probably the only other times that detectable amounts of $\Sigma$ DDx could have been resuspended and transported downstream, also likely at low concentrations less than 0.001 parts per billion. However, $\Sigma$ DDx was not detected in samples collected during those events, so the transport probably was minimal.

From the available evidence following initial applications of DDT to portions of the upper McKenzie River basin to fight budworm activity during the 1950s (Dolph, 1980; Moore and Loper, 1980), Cougar Reservoir apparently acted as a trap for sediment and residual DDT and metabolites until the time of the construction project in 2002. Meanwhile, other portions of the upper McKenzie River basin, where DDT also likely had been sprayed in the 1950s and 1960s, acted as a source of $\Sigma$ DDx to the lower basin between the 1950s and 2002 without a significant depositional basin to retain it upstream of Leaburg Reservoir. The detection of DDE in infiltration bags at VIDA, downstream of the South Fork, is consistent with this hypothesis. That no $\mathrm{DDDx}$ was detected in the mainstem upstream of Cougar Reservoir indicates that this upstream source probably has been mostly degraded or exported in the intervening decades.

Decreases in $\Sigma$ DDx concentrations apparently have been greatest in streambanks and sediments that are routinely wetted - residual concentrations in organic horizons in samples from forested soils upslope from Cougar Reservoir were significantly greater than those in the bed sediments (U.S. Army Corps of Engineers, 2003). Concentrations in soil samples from the forest floor in nearby regions collected by the U.S. Forest Service were equal to or slightly higher than those in streambanks collected by the Corps of Engineers, but were only about one-tenth of the highest concentration measured by the Corps of Engineers, which also was from the forest floor (Dave Kretzing, U.S. Forest Service, McKenzie Bridge, Oregon, unpub. data, 2003). Once construction began in 2002 at Cougar Reservoir, with the accompanying erosion and downstream transport of deposited sediments, the reservoir apparently began acting as a source for $\Sigma D D x$ to the South Fork and mainstem McKenzie River downstream. However, as a result of chemical and biological 
degradation and dilution, concentrations were relatively low and probably were not detectable even at sub-part-per-trillion concentrations, except when turbidities were highest during storm runoff and other construction-related events. This study did not examine 5 DDx in tissues of fish or other aquatic organisms, or top-level aquatic predators such as otters or raptors (see, for example, Henny and others, 1980), so the extent to which SDDx has bioaccumulated in the McKenzie River basin is unknown.

\section{Summary and Conclusions}

Cougar Reservoir was a substantial source of sediment to the South Fork and mainstem McKenzie Rivers between spring 2002 and December 2003. However, sediment transport decreased during calendar year 2004, effectively muting the relative importance of Cougar Reservoir and elevating the relative contribution from upstream sources on the mainstem. Evidence for the importance of Cougar Reservoir releases includes the increased turbidity and suspended-sediment concentrations at CGRO and VIDA as compared to upstream sites not influenced by Cougar Reservoir, the large proportion of the annual load at VIDA that was accounted for by the load at CGRO during water years 2003 and 2004, and the increased percentage of fine material collected by infiltration bags during 2003-04. Erosion of the deltaic sediments within the drawn-down, upstream reaches of the reservoir, which occurred primarily during spring 2002 and then episodically during the winters of 2002 and 2003, was apparently the largest source of sediment; however, the lack of turbidity monitoring at VIDA, MRBO, and BLUE until January 2003 make complete assessment of the relative contributions from the reservoir impossible. Judging from a mass balance on the suspended-sediment loads, most of the suspended sediment transported from Cougar Reservoir to the McKenzie River during 2003-05 also was transported downstream beyond the VIDA station.

DDT and its metabolites ( $\mathrm{DDDx}$ ) were detected in the reservoir and streambank sediments, as well as in upland soils, prior to this study. However, the concentrations were low, requiring a large re-mobilization of sediments, with suspended-sediment concentrations possibly greater than $100 \mathrm{mg} / \mathrm{L}$, for the $\Sigma \mathrm{DD}$ x to be transported downstream in detectable concentrations. The reservoir likely was a sink for DDT applied to the South Fork basin during the 1960s, whereas applications to the other sections of the McKenzie River basin probably were acting as sources since the 1960 s. Transport of sediment from Cougar Reservoir during the drawdown may have caused small amounts of $\Sigma$ DDx to be released from the reservoir but $\Sigma$ DDx probably would have been diluted to non-detectable concentrations by the time it entered the McKenzie River. The detection of low concentrations of $\Sigma$ DDx only in infiltration bags downstream of Cougar Reservoir and at VIDA supports the idea that the effect of the $\Sigma$ DDx release from the reservoir was limited.

Lessons learned from the experience at Cougar Reservoir can be useful for reservoir management within the Willamette River Basin and for future reservoir construction if substantial drawdowns below the normal low pool are required.

Although careful management of reservoir pool elevations and streamflows might avoid some problems from migration of exposed channels and downstream sediment transport, some amount of erosion may be unavoidable. Installation of a complete network of turbidity monitoring, coupled with collection of suspended-sediment data prior to the drawdown, would allow for better post-construction evaluation of the role of the construction on sediment transport and areas of likely deposition. The role of normal flood-control reservoir operation practices in downstream deposition of fine materials also remains unclear. Additional investigations of sediment deposition patterns, using either freeze cores, infiltration bags, or other methods, may help confirm whether processes common to reservoir management contribute to increased deposition of fine material. The generation of periodic, bedmoving events in reservoir tailraces also may help minimize the accumulation of fine sediment.

\section{Acknowledgments}

The author is indebted to the many people who provided assistance on this study. Major funding, logistics, and other support came from the U.S. Army Corps of Engineers (USACE), particularly Jim Britton, Tim Sherman, and Patrick O'Brien. Funding for data collection at Hayden Bridge was provided by Karl Morgenstern, Eugene Water and Electric Board, who also helped with infiltration bag installation and retrieval, and provided data. John Haines, Dave Sobale, and Terry Sobecki (USACE) helped with planning and retrieval of the infiltration bags. Chuck Willis (USACE) and Lynne Krasnow (NOAA Fisheries) helped secure permits for the installation and retreival of the infiltration bags, and Mark Wade and crew from the Oregon Department of Fish and Wildlife helped locate spawning gravels for the infiltration bags and on occasion retrieved errant equipment. From the U.S. Forest Service (USFS), Dave Kretzing, Phil Raab, and Jeff Ziller provided data and local assistance. Gordon Grant (USFS), Greg Stewart, Anne Jefferson, Sarah Lewis (Oregon State University), and Sirla Froig provided freeze core data, 
field assistance, and inspiration. Within USGS, Heather Bragg spent many hours designing and building the infiltration bags, and helped with their installation. Also helping install and (or) retrieve installation bags were Beth Rapp, Charlie Palmer, Troy Blackledge, and Ian Wigger. Sediment sampling was performed in all weather conditions by Ian Wigger, Micelis Doyle, Anna Buckley, and Doug Cushman. Turbidity and discharge monitoring stations were installed and operated by Doug Cushman and Jay Spillum, with oversight from Glen Hess. Jim O'Connor helped understand sediment dynamics with many hours of discussion and site inspections. This manuscript benefited from helpful reviews by Pat Rasmussen (USGS), Greg Stewart (Oregon State University), and Jim Britton and Patrick O'Brien (USACE).

\section{References Cited}

Anderson, C.W., 2004, Turbidity (version 2.0, 8/2004): U.S. Geological Survey Techniques of Water Resources Investigations, book 9, chap. A6, sec. 6.7, 64 p.

ASTM International, 2003, D1889-00 Standard test method for turbidity of water, in Annual Book of Standards, Water and Environmental Technology: West Conshohocken, Penn., American Society for Testing and Materials International, p. 6.

Brumberger, H., Stein, R.S., and Powell, R., 1968, Light scattering: Science and Technology, p. 34-42.

Brunke, M., and Gonser, T., 1997, The ecological significance of exchange processes between rivers and ground water: Freshwater Biology, v. 37, p. 1-33.

Christensen, V.G., Jian, X., and Ziegler, A.C., 2000, Regression analysis and real-time water-quality monitoring to estimate constituent concentrations, loads, and yields in the Little Arkansas River, south-central Kansas, 1995-99: U.S. Geological Survey Water-Resources Investigations Report 00-4126, 36 p.

Collier, M., Webb, R.H., and Schmidt, J.C., 1996, Dams and rivers-Primer on the downstream effects of dams: U.S. Geological Survey Circular 1126, 94 p.

Dolph, R.E., 1980, Budworm activity-Oregon and Washington, 1947-1979: U.S. Department of Agriculture, Forest Service, Pacific Northwest Region Forest and Disease Management Report R6-FIDM-033-1980, 54 p.
Edwards, T.K., and Glysson, G.D., 1999, Field methods for measurement of fluvial sediment: Techniques of WaterResources Investigations of the U.S. Geological Survey, book 3, chap. C2, 89 p.

Grant, G.E., Lewis, S.L., and Kast, P., 2002, Sediment mass balance for Cougar Reservoir sediment releases: Oregon State University, Unpublished report prepared for U.S. Army Corps of Engineers, Portland District Office.

Gray, J.R., and Glysson, G.D., 2003, Proceedings of the Federal Interagency Workshop on turbidity and other sediment surrogates, April 30-May 2, 2002, Reno, Nevada: U.S. Geological Survey Circular 1250, 56 p.

Helsel, D.R., and Hirsch, R.B., 1992, Statistical methods in water resources: Amsterdam, Elsevier.

Henny, C.J., Blus, L.J., Gregory, S.V., and Stafford, C.J., 1980, PCBs and organochlorine pesticides in wild mink and river otters from Oregon, in Proceedings of the Worldwide Furbearer Conference: Frostburg, Mo., p. 1763-1780.

Horowitz, A.J., Smith, J.J., and Elrick, K.A., 2001, Selected laboratory evaluations of the whole-water sample-splitting capabilities of a prototype fourteen-liter Teflon churn splitter: U.S. Geological Survey Open-File Report 01-386, $12 \mathrm{p}$.

Johnson, D.M., Peterson, R.R., Lycan, D.R., Sweet, J.W., Neuhaus, M.E., and Schaedel, A.L., 1985, Atlas of Oregon lakes: Corvallis, Oreg., Oregon State University Press, 318 p.

Lewis, J., 1996, Turbidity-controlled suspended sediment sampling for runoff-event load estimation: Water Resources Research, v. 32, no. 7, p. 2299-2310.

Lisle, T.E., and Eads, R.E., 1991, Methods to measure sedimentation of spawning gravels: U.S. Department of Agriculture, Forest Service, Pacific Southwest Research Station Research Note PSW-411, 7 p.

McGregor, J., 2000, Development of the US DH-95 suspended sediment sampler: Federal Interagency Sedimentation Project, Waterways Experiment Station, Vicksburg, Mississippi, $30 \mathrm{p}$.

McKee, B., 1972, Cascadia-The geological evolution of the Pacific Northwest: New York, McGraw Hill, 394 p.

Meyer, C.B., 2003, The importance of measuring biotic and abiotic factors in the lower egg pocket to predict coho salmon egg survival: Journal of Fish Biology, v. 62, no. 3, p. 534-548. 
Moore, D.G., and Loper, B.R., 1980, DDT residues in forest floors and soils of western Oregon, September-November, 1966: Pesticides Monitoring Journal, v. 14, no. 3, p. 77-85.

Rantz, S.E., and others, 1982, Measurement and computation of streamflow-Volume 2, Computation of discharge: U.S. Geological Survey Water Supply Paper 2175, 2 v., p. 285$631 \mathrm{p}$.

Sadar, M.J., 1998, Turbidity science: Hach Company, Loveland Colorado, Technical Information Series-Booklet No. 11, 26 p.

Sun, H., Cornish, P.S., and Daniell, T.M., 2001, Turbiditybased erosion estimation in a catchment in South Australia: Journal of Hydrology, v. 253, no. 2001, p. 227-238.

Tague, C., and Grant, G.E., 2004, A geological framework for interpreting the low-flow regimes of Cascade streams, Willamette River Basin, Oregon: Water Resources Research, v. 40, W04303, doi10.1029/2003WR002629, 9 p.

Uhrich, M.A., and Bragg, H.M., 2003, Monitoring instream turbidity to estimate continuous suspended-sediment loads and yields and clay-water volumes in the Upper North Santiam River Basin, Oregon, 1998-2000: U.S. Geological Survey Water-Resources Investigations Report 2003-4098, $43 \mathrm{p}$.

U.S. Army Corps of Engineers, 2003, Draft supplemental information report, Willamette temperature control, McKenzie River sub-basin, Oregon, Cougar Dam and Reservoir: U.S. Army Corps of Engineers, Portland District., 40 p, plus appendixes.
U.S. Environmental Protection Agency, 2006, Review of national primary drinking water regulations: Analytical methods-Reassessment of practical quantitation limits: Cincinnati, U.S. Environmental Protection Agency, accessed June 13, 2006, at http://www.epa.gov/safewater/ standard/review/methods.html

U.S. Geological Survey, 2001-2005, Water Resources Data, Oregon, Water Years 2000-2004: U.S. Geological Survey Water Data Reports OR-00-04-1.

Wagner, R.J., Boulger, R.W., Jr., Oblinger, C.J., and Smith, B.A., 2006, Guidelines and standard procedures for continuous water-quality monitors-Station operation, record computation, and data reporting: U.S. Geological Survey Techniques and Methods 1-D3, 51 p. plus 8 attachments, accessed April 10, 2006, at http://pubs.water.usgs.gov/ $\underline{\operatorname{tm} 1 \mathrm{~d} 3}$

Wilde, F.D., 2004, Cleaning of equipment for water sampling (version 2.0): U.S. Geological Survey Techniques of WaterResources Investigations, book 9, chap. A3.

Wilde, F.D., Radtke, D.B., Gibs, J., and Iwatsubo, R.T., 1999, Collection of water samples: U.S. Geological Survey Techniques of Water-Resources Investigations, book 9, chap. A4.

Wilde, F.D., Radtke, D.B., Gibs, J., and Iwatsubo, R.T., 2004, Processing of water samples (version 2.1): U.S. Geological Survey Techniques of Water-Resources Investigations book 9 , chap. A5. 
This page left intentionally blank 


\section{Appendixes}

Data files are presented in three Microsoft ${ }^{\circledR}$ Excel spreadsheets. The appendixes can be accessed and downloaded at URL http://pubs.usgs.gov/sir/2007/5164.

Appendix A. Mean daily discharge and estimated mean daily suspended-sediment in the McKenzie River Basin, Oregon, water years 2002-04.

Appendix B. Laboratory data for analysis of organochlorine compounds in water and sediment sampled during storms in 2003, McKenzie River Basin, Oregon.

Appendix C. Laboratory data for analysis of organochlorine compounds in sediment trap liquid and solid materials and particle size of sediment-trap solid materials. 
This page left intentionally blank 
Manuscript approved for publication, August 3, 2007

Prepared by the USGS Publishing Network,

Bill Gibbs

Robert Crist

Ellen Hardy

Bobbie Jo Richey

Linda Rogers

Sharon Wahlstrom

For more information concerning the research in this report, contact the Director, Oregon Water Science Center

U.S. Geological Survey

2130 SW 5th Avenue

Portland, Oregon 97201

http://or.water.usgs.gov 


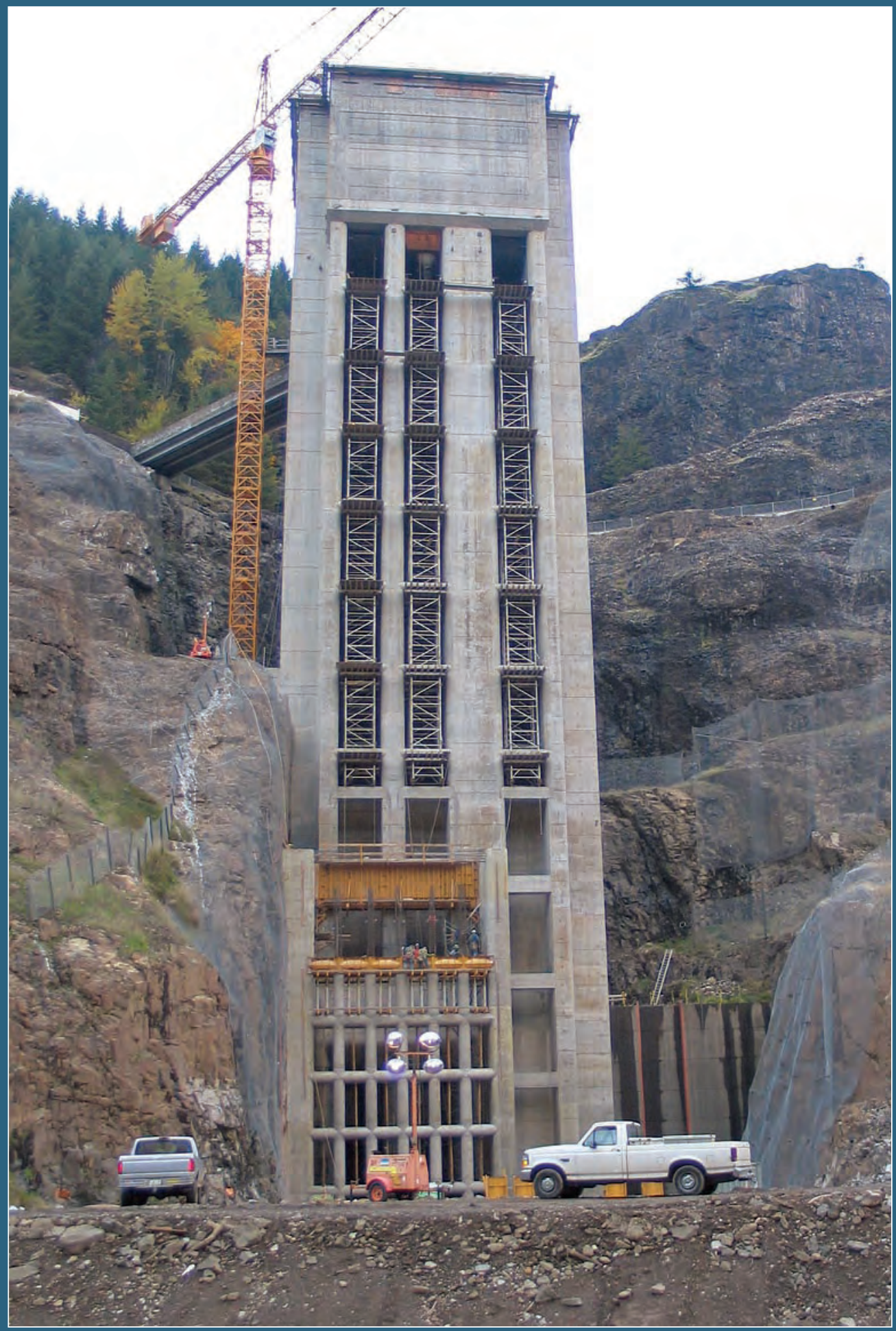

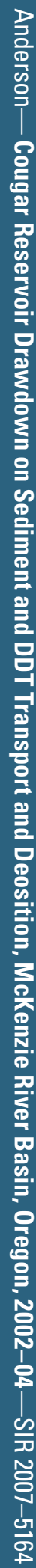

